\title{
Diastereoselective Gold(I)-Catalyzed [2+2+2] Cycloaddition of Oxo-1,5-enynes
}

\author{
Pilar Calleja ${ }^{\text {at }}$ \\ Michael E. Muratore ${ }^{\mathrm{a} \ddagger}$ \\ Tania Jiménez ${ }^{\mathrm{a}}$ \\ Antonio M. Echavarren*a,b \\ a Institute of Chemical Research of Catalonia (ICIQ), Barcelona Institute of \\ Science and Technology, Av. Països Catalans 16, 43007 Tarragona, Spain \\ ${ }^{\mathrm{b}}$ Departament de Química Orgànica i Analítica, Universitat Rovira i Virgili, \\ C/ Marcel-lí Domingo s/n, 43007 Tarragona, Spain \\ aechavarren@iciq.es \\ $\ddagger$ These authors contributed equally. \\ In memory of Professor Jean Normant.
}

Received: 21.05.2016

Accepted after revision: 13.06.2016

Published online: 19.07 .2016

DOI: 10.1055/s-0035-1562452; Art ID: ss-2016-c0371-op

License terms: (C) (P)

Abstract The intramolecular gold(1)-catalyzed $[2+2+2]$ cycloaddition of oxo-1,5-enynes bearing protected homopropargylic alcohols provides access to oxatricyclic adducts with good to excellent diastereoselectivity.

Key words gold, enynes, cycloisomerization, cycloaddition, Prins reaction

The cycloisomerization of 1,n-enynes catalyzed by gold(I) and other electrophilic metals is a powerful tool for the construction of complex carbocycles and heterocycles, including core scaffolds of biologically active natural products. $^{1-3}$ We have reported that oxo-1,6-enynes react in the presence of gold(I) complexes to give oxatricyclic compounds through a formal [2+2+2] alkyne/alkene/carbonyl cycloaddition process. ${ }^{4}$ The transformation presumably proceeds by attack of the carbonyl on the cyclopropyl gold carbene intermediate followed by Prins cyclization and deauration to afford the final oxatricyclic derivative. ${ }^{4}$ In a similar vein, terminal alkynes and 5-oxoalkenes undergo a $[2+2+2]$ cycloaddition reaction by intermolecular cyclization of the alkyne and the alkene followed by intramolecular attack of the carbonyl group to form [3.2.1]oxabicycles. ${ }^{5,6}$ Very recently, our group reported a similar transformation involving simple oxo-1,7-allenenes to afford bicyclo[6.3.0] undecane ring systems. ${ }^{7}$ The related gold(I)catalyzed intermolecular reaction between allenamides and oxoalkenes forms seven- to nine-membered rings. ${ }^{8}$

The synthetic potential of this $[2+2+2]$ alkyne/alkene/carbonyl cycloaddition has been exploited for the synthesis of several oxygen-bridged sesquiterpenoids, such as (+)-orientalol $F(\mathbf{1})^{3 a}$ and (-)-englerin $A$
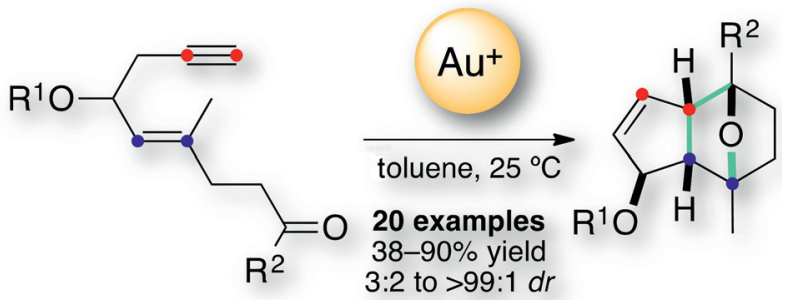

$(2)^{3 \mathrm{~b}, 9}$ (Figure 1 ). We envisaged that other naturally occurring compounds, such as isovelerenol $(\mathbf{3})^{10}$ and bakkenolide III $(4)^{11}$ with an octahydro- $1 H$-indene core (Figure 2 ) could be accessed starting from adequately functionalized oxo1,5-enynes; however, examples involving those enynes are scarce. ${ }^{1,12}$

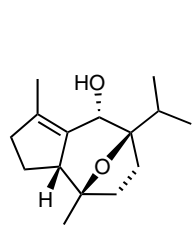

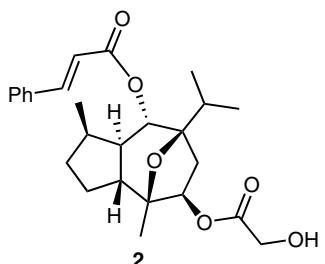

Figure 1 Naturally occurring sesquiterpenes with a decahydro-4,8-epoxyazulene structure

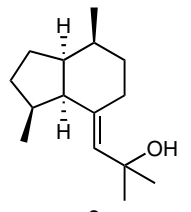

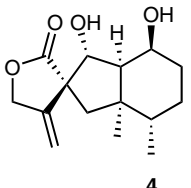

Figure 2 Naturally occurring sesquiterpenes with an octahydro- $1 \mathrm{H}$-indene structure

In a preliminary study, we found that $(E)$ - and $(Z)$ enynals 5 bearing a phenylsulfonyl group at the tether undergo an analogous cycloaddition reaction cascade to form related oxatricyclic adducts (Scheme 1 ). ${ }^{12}$ Surprisingly, the cyclization of substrate $(E)-\mathbf{5}$ was found to be poorly stereoselective yielding syn-6 and anti-6 in ratios that ranged from $1: 1.5$ to $3-4: 1$, whereas good stereoselectivities were achieved in the transformation of $(Z)-5$ into anti-6 (20-30:1 $d r)$. We argued that these results could be explained if a stepwise process was occurring through diastereomeric in- 
termediates that could undergo intramolecular nucleophilic attack of the carbonyl group by inversion or retention of the configuration. ${ }^{12}$

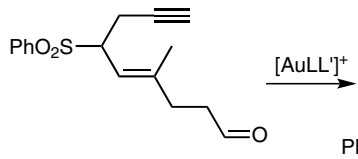

$(E)-5$

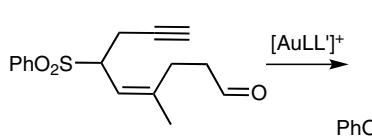

$(Z)-5$

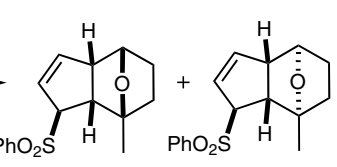

syn-6

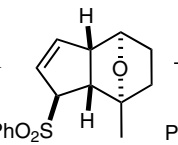

anti-6

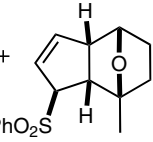

syn-6
Scheme 1 Gold(I)-catalyzed reaction of (E)- and (Z)-enynals 5

Therefore, we decided to study the stereoselectivity in the reaction of other differently substituted substrates. Herein, we wish to report our findings on the scope of the cycloaddition cascade of $\mathrm{O}$-protected homopropargylic and allylic oxo-1,5-enynes. A theoretical study has also been performed to support the mechanism of this transformation and to explain the overall stereoselectivity of this process.

We first investigated the reaction of (Z)-6-methyl-9oxonon-5-en-1-yn-4-yl benzoate $[(Z)-7 \mathbf{a}]$ as the model substrate, using $5 \mathrm{~mol} \%$ of commercially available cationic JohnPhos-gold(I) catalyst A (Figure 3) at $25{ }^{\circ} \mathrm{C}$ in $\mathrm{CH}_{2} \mathrm{Cl}_{2}$. Under these conditions, we observed complete conversion of $(Z)-7 \mathbf{a}$ to afford the cyclization product anti-8a in moderate yield (Table 1, entry 1 ) together with decomposition products. Various solvents were also evaluated in order to find the optimum conditions (Table 1, entries 2-7). Whereas no cycloisomerization was observed in THF, DME, DMSO, $\mathrm{DMF}, \mathrm{MeCN}$ or $\mathrm{MeOH},{ }^{13}$ the reaction proceeded in chlorinated or aromatic solvents. The best results were observed in toluene (Table 1, entry 5) giving rise to anti-8a in higher yield. Thus, toluene was selected for further optimization. Efforts to improve this cyclization cascade using other gold catalysts were unsuccessful (Table 1, entries 8-14). Although the reaction proceeded well with gold catalyst $\mathbf{E}$ (Table 1, entry 11), the use of sterically hindered phosphines resulted in a decrease in selectivity. To our delight, decreasing the concentration from 0.1 to $0.01 \mathrm{M}$ substantially improved the reaction yield while maintaining the selectivity (Table 1, entries 5, 15 and 16). Further studies revealed that longer reaction times did not have any detrimental influence on the outcome of the transformation (Table 1, entry $18 ; 88 \%$ yield, $91: 9 d r$ ), and that performing the reaction at lower temperature did not improve the stereoselectivity (Table 1, entry 17 ). Under the optimized conditions, the cyclization of $(Z)-7 a$ led to the formation of anti-8a in 90\% isolated yield (92:8 dr). Additionally, the configuration of the major isomer could be confirmed by $\mathrm{X}$ ray diffraction (Figure 4, anti-8a).

With optimized conditions in hand, we sought to evaluate the generality of the reaction. Different $(Z)$ - and $(E)$ oxo-1,5-enynes bearing protected homopropargylic alcohols were prepared in four to six steps starting from commercially available nerol and geraniol, respectively (see experimental section). In general, moderate to good yields (38-90\%) of the corresponding oxatricyclic adducts anti$\mathbf{8 a}-\mathbf{j}$, syn-8a-e, syn-8g-i and syn-8k-1 were obtained (Tables 2 and 3). Notably, the [2+2+2]-cycloaddition process never occurred with complete stereoselectivity.

All the studied ( $Z$ )-1,5-enynes $\mathbf{7 a - j}$ cyclized with good to high diastereoselectivities (Table 2). The sterics of the substituent attached to the carbonyl group ( $\mathrm{R}^{2}$ in Table 2 ) did not seem to have a clear influence on the stereoselectiv-

Table 1 Optimization of the Gold-Catalyzed Cyclization of (Z)-7a

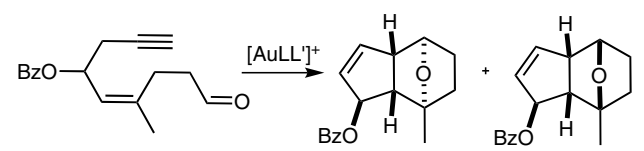

(Z)-7a

anti-8a

syn-8a

\begin{tabular}{|c|c|c|c|c|c|c|c|}
\hline Entry & Cat. & Solvent & {$[\mathrm{M}]$} & $\begin{array}{l}\text { Time } \\
\text { (h) }\end{array}$ & $\begin{array}{l}\text { Temp } \\
\left({ }^{\circ} \mathrm{C}\right)\end{array}$ & $\begin{array}{l}\text { Yield of } \\
\text { anti-8a (\%) }\end{array}$ & $\begin{array}{l}\text { Ratio } \\
\text { anti/syn }\end{array}$ \\
\hline 1 & A & $\mathrm{CH}_{2} \mathrm{Cl}_{2}$ & 0.1 & 3 & 25 & 55 & $93: 7$ \\
\hline 2 & A & DCE & 0.1 & 3 & 25 & 46 & $91: 9$ \\
\hline 3 & A & $\mathrm{CDCl}_{3}$ & 0.1 & 3 & 25 & 62 & $91: 9$ \\
\hline 4 & A & benzene & 0.1 & 3 & 25 & 64 & $89: 11$ \\
\hline 5 & A & toluene & 0.1 & 3 & 25 & 66 & $92: 8$ \\
\hline 6 & A & $\mathrm{PhCF}_{3}$ & 0.1 & 3 & 25 & $41(95)^{b}$ & $89: 11$ \\
\hline 7 & A & $\mathrm{PhCl}$ & 0.1 & 3 & 25 & 36 & $88: 12$ \\
\hline 8 & B & toluene & 0.1 & 2 & 25 & $29(80)^{b}$ & $65: 35$ \\
\hline 9 & C & toluene & 0.1 & 2 & 25 & $<1(<5)^{b}$ & n.d.c \\
\hline 10 & D & toluene & 0.1 & 2 & 25 & $32(95)^{b}$ & $73: 27$ \\
\hline 11 & $\mathrm{E}$ & toluene & 0.1 & 2 & 25 & 66 & $81: 19$ \\
\hline 12 & $\mathrm{~F}$ & toluene & 0.1 & 3 & 25 & $25(90)^{\mathrm{b}}$ & $68: 32$ \\
\hline 13 & G & toluene & 0.1 & 3 & 25 & 12 & n.d. ${ }^{c}$ \\
\hline 14 & $\mathrm{H}$ & toluene & 0.1 & 3 & 25 & $6(50)^{\mathrm{b}}$ & n.d. ${ }^{c}$ \\
\hline 15 & A & toluene & 0.05 & 2 & 25 & 66 & $90: 10$ \\
\hline $16^{d}$ & A & toluene & 0.01 & 6 & 25 & 83 & $92: 8$ \\
\hline 17 & A & toluene & 0.01 & 24 & 0 & 83 & $92: 8$ \\
\hline 18 & A & toluene & 0.01 & 15 & 25 & 88 & 91:9 \\
\hline
\end{tabular}

a Determined by ${ }^{1} \mathrm{H}$ NMR (mesitylene as internal standard).

b $\%$ of conversion, $100 \%$ if not stated otherwise.

c Not determined.

d Average yield of 3 runs. 


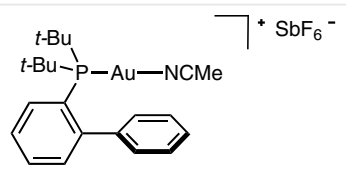

A

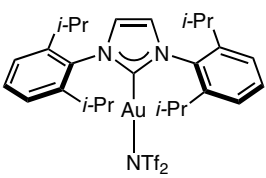

C

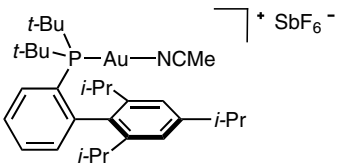

E<smiles>CC(C)[AsH2-]C(C)C</smiles>

G

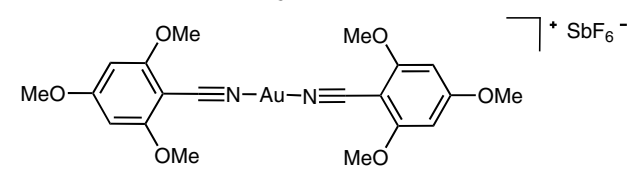

H

Figure 3 Gold catalysts

ity, however, the bulkier TBS protecting group of the alcohol improved the overall diastereoselectivity of the formal cycloaddition compared to the benzoate. The high stereoselectivities observed with $(Z)$-enynes are in agreement with the previous observations for the related transformation developed in our group. ${ }^{12}$ These oxatricycles were formed in generally good yields and the major isomer can, in most cases, be isolated in virtually diastereomerically pure form by standard chromatographic methods or by crystallization. This allowed us to obtain the crystal structures of three derivatives, confirming that the major isomer formed in all cases has the same relative configuration, regardless of the nature of $\mathrm{R}^{1}$ and $\mathrm{R}^{2}$ (see Supporting Information, anti-8a, anti-8b and anti-8g). ${ }^{14}$

Interestingly, the cyclization of $(E)$-enynals $\mathbf{7 a}, \mathbf{b}$ and $\mathbf{7 k} \mathbf{1} \mathbf{1}$ also proceeded with excellent stereoselectivity to give the expected oxatricyclic products syn-8a,b and syn-8k,1 in satisfactory yields (Table 3, entries 1, 2, 9 and 10). Additionally, other $(E)$-keto-1,5-enynes $\mathbf{7 c - i}$ were also examined. As shown in Table 3, different trends were observed depending on the nature of the protecting group. Thus, alkyl- $[(E)-7 \mathbf{d}]$ and aryl-substituted [(E)-7h] TBS-protected keto-1,5enynes led to the formation of cyclized derivatives (Table 3,
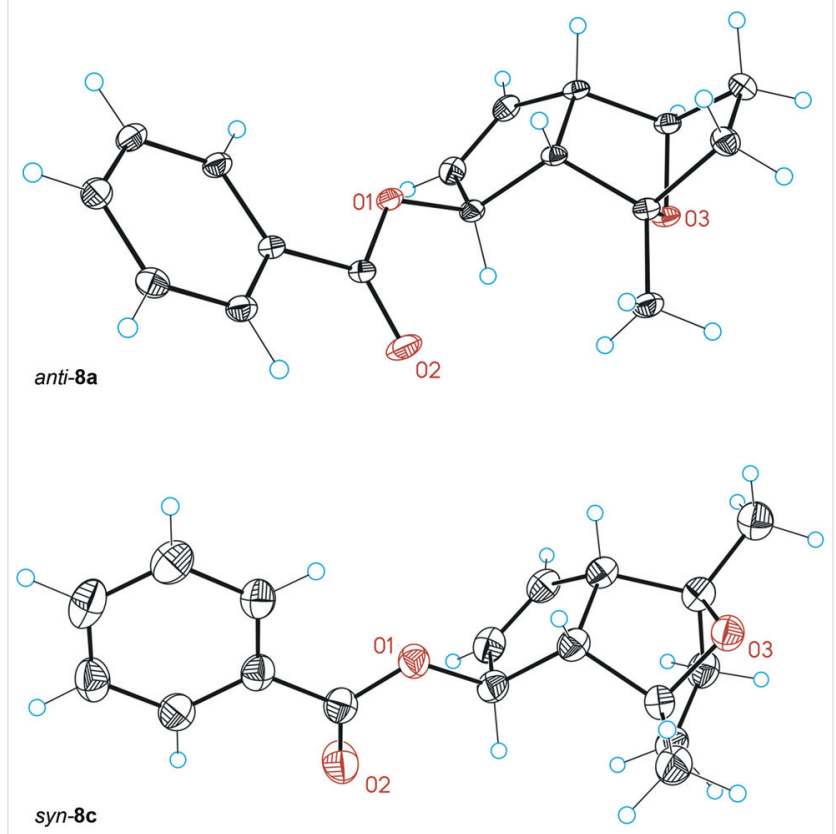

Figure 4 ORTEP representations of the X-ray crystal structures of anti$8 \mathbf{a}$ and syn-8c with $50 \%$ probability of the thermal ellipsoids

Table 2 Gold-Catalyzed Cyclization of (Z)-Oxo-enynes ${ }^{a}$

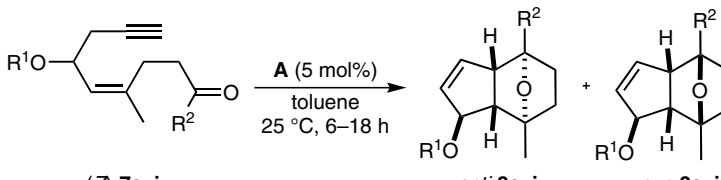

(Z)-7a-j

anti-8a-j

syn-8a-j

\begin{tabular}{|c|c|c|c|c|c|}
\hline Entry & Enyne & $\mathrm{R}^{1}$ & $\mathrm{R}^{2}$ & $\begin{array}{l}\text { Yield of anti-8 } \\
(\%)^{b}\end{array}$ & Ratio anti/syn \\
\hline 1 & $(Z)-7 a$ & $\mathrm{Bz}$ & $\mathrm{H}$ & 82 & $97: 3(91: 9)^{c}$ \\
\hline 2 & $(Z)-7 b$ & TBS & $\mathrm{H}$ & 58 & $\geq 98: 2(83: 17)^{c}$ \\
\hline 3 & $(Z)-7 c$ & $\mathrm{Bz}$ & Me & $79(55)^{d}$ & $83: 17(83: 17)^{c}$ \\
\hline 4 & $(Z)-7 d$ & TBS & $\mathrm{Me}$ & 70 & $>98: 2(>98: 2)^{c}$ \\
\hline 5 & $(Z)-7 e$ & $\mathrm{Bz}$ & $c-\mathrm{Pr}$ & 74 & $89: 11(83: 17)^{\mathrm{c}}$ \\
\hline 6 & $(Z)-7 f$ & $\mathrm{Bz}$ & $c$-Pent & 68 & $85: 15(84: 16)^{c}$ \\
\hline 7 & $(Z)-7 \mathbf{g}$ & $\mathrm{Bz}$ & $\mathrm{Ph}$ & $88(69)^{\mathrm{e}}$ & $93: 7(91: 9)^{c}$ \\
\hline 8 & (Z)-7h & TBS & $\mathrm{Ph}$ & $61^{\mathrm{e}}$ & $>98: 2(93: 7)^{c}$ \\
\hline 9 & $(Z)-7 \mathbf{i}$ & $\mathrm{Bz}$ & $\mathrm{C}_{6} \mathrm{H}_{4} \mathrm{CF}_{3}$ & 65 & $>98: 2(87: 13)^{c}$ \\
\hline 10 & $(Z)-7 \mathbf{j}$ & $\mathrm{Bz}$ & $2-N p^{f}$ & $56^{e}$ & $>98: 2(93: 7)^{c}$ \\
\hline
\end{tabular}

$[7]=0.01 \mathrm{M}$.

b Product yields are reported after purification.

c Crude $d r$ determined by NMR.

desult of crystallization $(d r \geq 98: 2)$.

e Result of crystallization ( $d r>98: 2)$.

f 2-Np = 2-naphthyl. 
entries 4 and 7) in good yields and with high selectivity. In contrast, benzoate-protected 1,5-enynes bearing bulky substituents on the ketone (Table 3, entries 5, 6 and 8) afforded the expected products, albeit with moderate yields and a dramatic loss of selectivity. The relative configurations of these compounds were assigned by analogy to that of syn-8c, which was established by X-ray crystallography (Figure 4, syn-8c).

Table 3 Gold-Catalyzed Cyclization of (E)-Oxo-enynes ${ }^{\text {a }}$

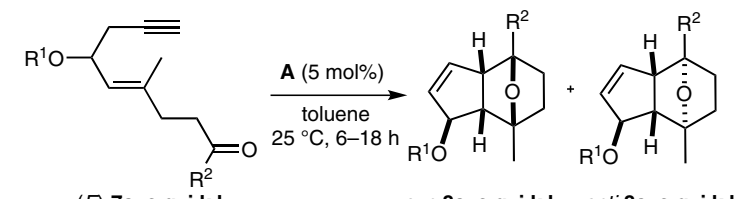

$(E)-7 \mathbf{a}-\mathbf{e}, \mathbf{g}-\mathbf{i}, \mathbf{k}, \mathbf{I}$

syn-8a-e, $\mathbf{g}-\mathbf{i}, \mathbf{k}, \mathbf{I} \quad$ anti-8a-e, $\mathbf{g}-\mathbf{i}, \mathbf{k}$,

\begin{tabular}{cllllc}
\hline Entry & Enyne & $\mathrm{R}^{1}$ & $\mathrm{R}^{2}$ & $\begin{array}{l}\text { Yield of } \\
\text { syn-8 (\%) }\end{array}$ & Ratio syn/anti \\
\hline 1 & $(E)-7 \mathbf{a}$ & $\mathrm{Bz}$ & $\mathrm{H}$ & 83 & $93: 7(93: 7)^{\mathrm{e}}$ \\
2 & $(E)-7 \mathbf{b}$ & TBS & $\mathrm{H}$ & 82 & $>99: 1(99: 1)^{\mathrm{e}}$ \\
$3^{c}$ & $(E)-7 \mathbf{c}$ & $\mathrm{Bz}$ & $\mathrm{Me}$ & 78 & $88: 12(89: 11)^{\mathrm{e}}$ \\
4 & $(E)-7 \mathbf{d}$ & $\mathrm{TBS}$ & $\mathrm{Me}$ & 65 & $>99: 1(99: 1)^{\mathrm{e}}$ \\
$5^{c}$ & $(E)-7 \mathbf{e}$ & $\mathrm{Bz}$ & $\mathrm{C}-\mathrm{Pr}$ & 52 & $82: 18(87: 13)^{\mathrm{e}}$ \\
$6^{c}$ & $(E)-7 \mathbf{g}$ & $\mathrm{Bz}$ & $\mathrm{Ph}$ & $38(20)^{\mathrm{f}}$ & $57: 43(58: 42)^{\mathrm{e}}$ \\
7 & $(E)-7 \mathbf{h}$ & $\mathrm{TBS}$ & $\mathrm{Ph}$ & 90 & $>99: 1(96: 4)^{\mathrm{e}}$ \\
8 & $(E)-7 \mathbf{i}$ & $\mathrm{Bz}$ & $\mathrm{C}_{6} \mathrm{H}_{4} \mathrm{CF}_{3}$ & 48 & $91: 9(83: 17)^{\mathrm{e}}$ \\
$9^{\mathrm{d}}$ & $(E)-7 \mathbf{7}$ & $\mathrm{MOM}$ & $\mathrm{H}$ & 81 & $>99: 1(99: 1)^{\mathrm{e}}$ \\
10 & $(E)-7 \mathbf{l}$ & TES & $\mathrm{H}$ & 71 & $>99: 1(95: 5)^{\mathrm{e}}$ \\
\hline
\end{tabular}

a $[7]=0.01 \mathrm{M}$.

b Product yields and $d r$ are reported after purification.

c Reaction at $30^{\circ} \mathrm{C}$.

d Reaction at $40{ }^{\circ} \mathrm{C}$.

e Crude $d r$ determined by NMR.

${ }^{\mathrm{f}}$ Result of crystallization (dr 56:44).

Intriguingly, the treatment of 1,5 -enyne $(E)$-7 $\mathbf{k}$ with cationic JohnPhos-gold(I) catalyst $\mathbf{A}$ ( $3 \mathrm{~mol} \%$ ) in $\mathrm{CH}_{2} \mathrm{Cl}_{2}$ instead of toluene at $23^{\circ} \mathrm{C}$ led to the isolation of unexpected crown ether $\mathbf{9}$, in low to moderate yield (Scheme 2). The structure

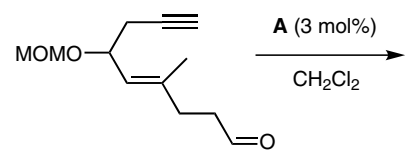

$(E)-7 \mathbf{k}$

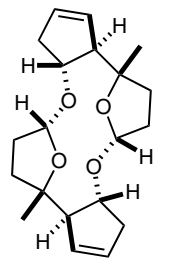

9

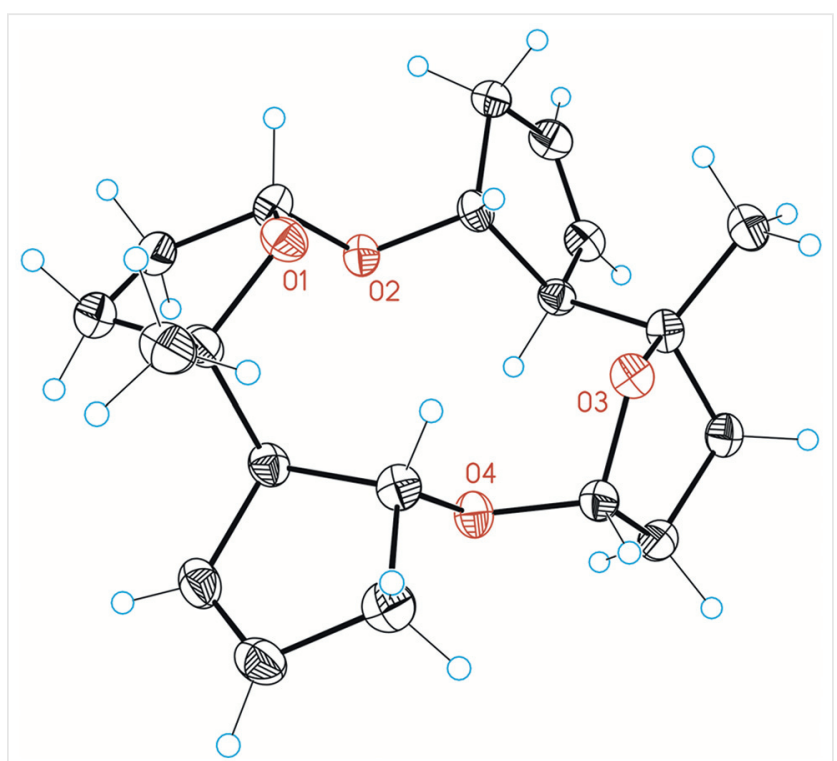

Figure 5 ORTEP representation of the X-ray crystal structure of $\mathbf{9}$ with $50 \%$ probability of the thermal ellipsoids

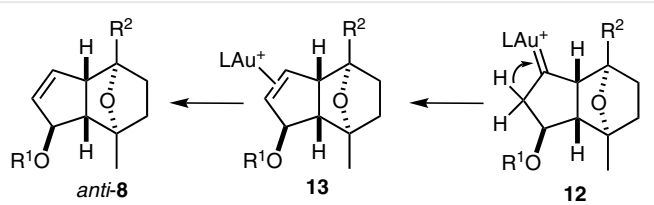

13

12<smiles>[Y10]C1=C[C@](C)(C2[O+]=C([R7])C[C@H]2O)CC1</smiles>

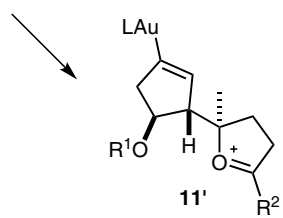

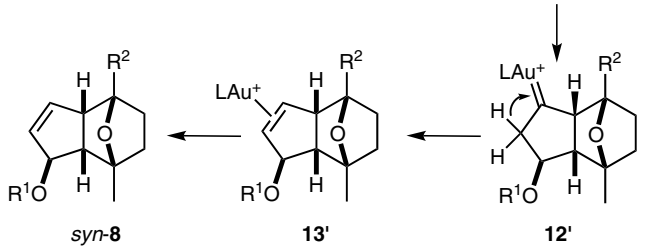

Scheme 3 Proposed mechanism for the formation of oxatricyclic derivatives syn-8 and anti-8 starting from enynals $(E)-7$

Scheme 2 Gold(I)-catalyzed reaction of oxo-enyne (E)-7k to give crown ether 9 
of this compound was confirmed by X-ray diffraction (Figure 5). The formation of $\mathbf{9}$ can be rationalized by the bimolecular reaction of two oxocarbenium intermediates 11' (Scheme 3, $R^{1}=R^{2}=H$ ), in which the protecting group has been cleaved under the conditions of the reaction.

We propose a mechanism for the formation of the oxatricyclic derivative syn-8 starting from $(E)-\mathbf{7}$ initiated by activation of the alkyne to form a cyclopropyl gold(I)-carbene 10, followed by the intramolecular attack of the carbonyl group to generate the oxocarbenium intermediate 11' (Scheme 3 ). Intermediate $\mathbf{1 1}$ ' could form a second $\mathrm{C}-\mathrm{C}$ bond through a Prins-type reaction with the alkenyl metal leading to carbene-like intermediate $\mathbf{1 2}^{\prime}$, which is reminiscent of the mechanism for the gold(I)-catalyzed reaction of oxo1,6-enynes. ${ }^{4}$ A final 1,2-H migration would lead to alkenegold(I) complex 13' after deauration and, ultimately, to product syn-8. The formation of the minor stereoisomer anti-8 from $(E)-\mathbf{7}$ is consistent with the existence of another competitive stepwise process. Thus, the nucleophilic at- tack of the carbonyl group on the opposite face of intermediate $\mathbf{1 0}$ would lead to isomer anti-8 through intermediates 11 and 12.

The mechanistic proposal outlined in Scheme 3 is supported by DFT calculations at the M06, 6-31G(d) (C, H, P, O) and SDD ( $\mathrm{Au}$ ) levels, taking into account the solvent effect (IEFPCM $=$ toluene) and employing $\mathrm{PMe}_{3}$ as the phosphine ligand (Figure 6 ). This study shows that the first cyclization giving rise to intermediate II (corresponding to $\mathbf{1 0}$ in Scheme 3 ) has the highest activation energy. It would thus be the rate-determining step if the ligand exchange equilibrium that regenerates the entering reactive species $\mathbf{I}$ from the final substrate-gold(I) complex is not considered. The calculated energy differences for the two competitive transition states, $\mathbf{T S}_{\text {II-III }}\left(\Delta \mathrm{G}^{\#}=3.3 \mathrm{kcal} \cdot \mathrm{mol}^{-1}\right)$ and $\mathbf{T S}$ III-v $\left(\Delta \mathrm{G}^{\#}=\right.$ $\left.9.5 \mathrm{kcal} \cdot \mathrm{mol}^{-1}\right)$, show that the formation of oxocarbenium intermediate III is kinetically more favored than the formation of $\mathbf{V}$, which is in general agreement with our experimental findings. Furthermore, our calculations support the

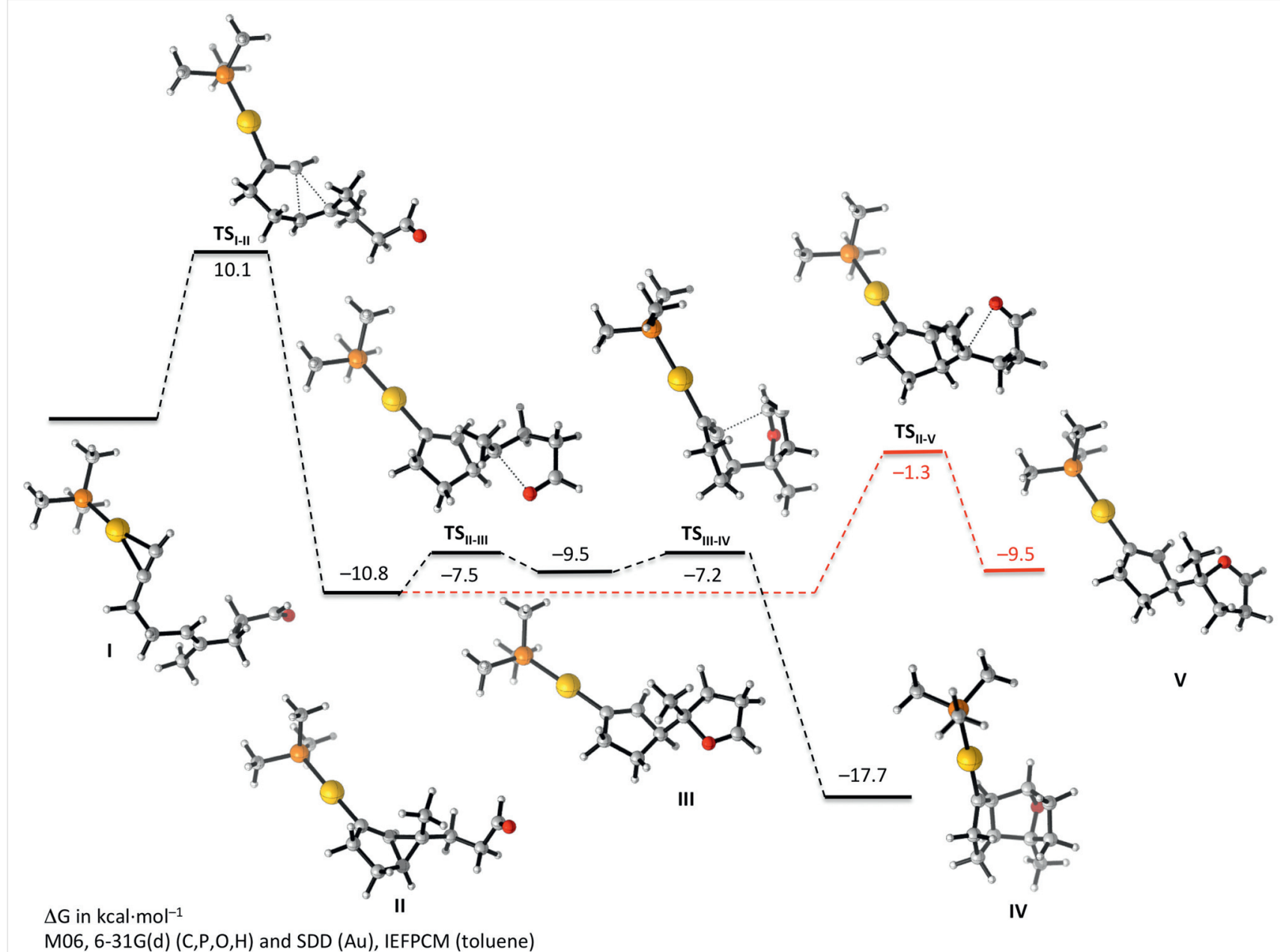

Figure 6 Energy profiles for the competitive reaction pathways of gold(I) complex I. DFT calculations: M06, 6-31G(d) (C, H, P, O) and SDD (Au), IEFPCM (toluene). Values for free energies in $\mathrm{kcal} \cdot \mathrm{mol}^{-1}$. 
existence of a discrete intermediate II in the cyclization of the 1,5 -enyne, ${ }^{15}$ which undergoes intramolecular nucleophilic opening to form preferentially intermediate III by an overall anti-type attack.

In summary, we have extended the scope of the intramolecular gold(I)-catalyzed formal $[2+2+2]$ cycloaddition reaction to 0 -protected homopropargylic and allylic oxo1,5-enynes. Under the optimized reaction conditions, the cyclization of $(Z)$ - and $(E)$-isomers takes place with moderate to excellent yield (38-90\%) and increased selectivity in most of the cases, providing access to substituted octahydro- $1 H$-indenes. DFT calculations suggest that after the formation of the cyclopropyl gold(I)-carbene, two competitive pathways arising from the preferred face for the nucleophilic attack of the carbonyl group are involved in this transformation and can explain the observed lack of complete stereoselectivity. Investigations toward the synthesis of larger ring systems to access other natural sesquiterpene motifs are currently underway.

Reactions were performed under argon atmosphere in solvents dried by passing through an activated alumina column on a PureSolv ${ }^{\mathrm{TM}}$ solvent purification system (Innovative Technologies, Inc., MA). Thinlayer chromatography was carried out using TLC aluminum sheets coated with $0.2 \mathrm{~mm}$ of silica gel (Merck Gf234). Chromatographic purifications were carried out using flash grade silica gel (SDS Chromatogel 60 ACC, 40-60 $\mu \mathrm{m}$ ). Melting points were determined using a Büchi melting point apparatus. NMR spectra were recorded at $25^{\circ} \mathrm{C}$ on a Bruker Avance 300, 400 Ultrashield and Bruker Avance 500 Ultrashield apparatus. The data are reported as such: chemical shift $(\delta$, $\mathrm{ppm}$ ) [multiplicity, coupling constant ( $\mathrm{Hz})$, integration]. The chemical shifts are given in ppm downfield from tetramethylsilane using the residual protiosolvent as internal reference. The abbreviations for multiplicities are: $\mathrm{s}$ (singlet), $\mathrm{d}$ (doublet), $\mathrm{t}$ (triplet), $\mathrm{q}$ (quartet), quin (quintet), sext (sextet), sept (septet). Mass spectra were recorded on a Waters Micromass LCT Premier (ESI) instrument. Crystal structure determinations were carried out using a Bruker-Nonius diffractometer equipped with an APEX II 4K CCD area detector, an FR591 rotating anode with MoK $\alpha$ radiation, Montel mirrors as the monochromator and a Kryoflex low temperature device $\left(\mathrm{T}=-173^{\circ} \mathrm{C}\right)$. Full-sphere data collection was used with $\mathrm{w}$ and $\mathrm{j}$ scans. Programs used: data collection APEX-2, data reduction Bruker Saint V/.60A and absorption correction SADABS. Structure solution and refinement: crystal structure solution was achieved using direct methods as implemented in SHELXTL and visualized using the program XP. Missing atoms were subsequently located from difference Fourier synthesis and added to the atom list. Least-squares refinement on F2 using all measured intensities was carried out using the program SHELXTL. All non-hydrogen atoms were refined including anisotropic displacement parameters.

\section{Allylic Homopropargylic Protected Alcohols S1; General Proce- dure}

(E)-6,10-Dimethylundeca-5,9-dien-1-yn-4-ol [(E)-S1] and (Z)-6,10dimethylundeca-5,9-dien-1-yn-4-ol [(Z)-S1] were prepared according to known literature procedures..$^{16}$ Spectroscopic data were in agreement with those reported (see Supporting Information).

\section{Preparation of Benzoic Esters of S1 (S2a)}

In a dry round-bottom flask under argon, $\mathbf{S} \mathbf{1}$ (1 equiv) was dissolved in pyridine ( $1 \mathrm{M}$ solution) and the solution was cooled to $0{ }^{\circ} \mathrm{C}$. Benzoyl chloride (1.1 equiv) was added slowly dropwise. The mixture was stirred at $0{ }^{\circ} \mathrm{C}$ for $1 \mathrm{~h}$ after which time TLC indicated full conversion of S1. The suspension was poured over $3-5 \%$ aq $\mathrm{HCl}$ ( 10 volumes of pyridine $)$ and extracted with $\mathrm{Et}_{2} \mathrm{O}\left(2 \times\right.$ volume $\left.\mathrm{HCl}_{\mathrm{aq}}\right)$. The combined ethereal extracts were washed with $3-5 \%$ aq $\mathrm{HCl}(5 \times 1 / 2$ initial volume $\mathrm{HCl}_{\mathrm{aq}}$ ), the washed organic phase dried over $\mathrm{Na}_{2} \mathrm{SO}_{4}$ and the filtrate concentrated. The crude material was purified by column chromatography on silica gel eluting with pentane/ $\mathrm{Et}_{2} \mathrm{O}$ (98:2 to 9:1) or cyclohexane/EtOAc (95:5 to 9:1).

\section{(E)-6,10-Dimethylundeca-5,9-dien-1-yn-4-yl Benzoate [(E)-S2a]}

Prepared on $3 \mathrm{~g}$ scale from (E)-S1; the product was isolated as a pale yellow oil ( $3.70 \mathrm{~g}, 80 \%)$.

${ }^{1} \mathrm{H}$ NMR $\left(400 \mathrm{MHz}, \mathrm{CDCl}_{3}\right): \delta=8.08-8.03(\mathrm{~m}, 2 \mathrm{H}), 7.58-7.52(\mathrm{~m}, 1 \mathrm{H})$, 7.46-7.40 (m, $2 \mathrm{H}$ ), 5.87 (dt, $J=9.1,6.1 \mathrm{~Hz}, 1 \mathrm{H}$ ), 5.35 (dq, $J=9.1,1.3$ $\mathrm{Hz}, 1 \mathrm{H}$ ), 5.08 (tq, $J=5.4,1.6 \mathrm{~Hz}, 1 \mathrm{H}$ ), 2.71-2.55 (m, $2 \mathrm{H}$ ), 2.16-2.02 $(\mathrm{m}, 4 \mathrm{H}), 1.98(\mathrm{t}, J=2.6 \mathrm{~Hz}, 1 \mathrm{H}), 1.82(\mathrm{~d}, J=1.4 \mathrm{~Hz}, 3 \mathrm{H}), 1.65(\mathrm{~d}, J=1.4$ $\mathrm{Hz}, 3 \mathrm{H}$ ), 1.59 (app s, $3 \mathrm{H}$ ).

${ }^{13} \mathrm{C}$ NMR (101 MHz, $\mathrm{CDCl}_{3}$ ): $\delta=165.9,142.3,133.0,131.9,130.6$, 129.8 (2 C), 128.4 (2 C), 123.8, 122.0, 79.9, 70.3, 69.7, 39.7, 26.4, 25.8, $25.3,17.9,17.2$.

HRMS (ESI+): $m / z$ [M $+\mathrm{Na}]^{+}$calcd for $\mathrm{C}_{20} \mathrm{H}_{24} \mathrm{O}_{2} \mathrm{Na}$ : 319.1669; found: 319.1666 .

(Z)-6,10-Dimethylundeca-5,9-dien-1-yn-4-yl Benzoate [(Z)-S2a]

Prepared on $2.5 \mathrm{~g}$ scale from $(Z)-\mathbf{S 1}$; the product was isolated as a pale yellow oil ( $2.90 \mathrm{~g}, 84 \%)$.

${ }^{1} \mathrm{H}$ NMR $\left(500 \mathrm{MHz}, \mathrm{CDCl}_{3}\right.$ ): $\delta=8.09-8.04(\mathrm{~m}, 2 \mathrm{H}), 7.55$ (ddt, $J=8.8$, 7.0, $1.4 \mathrm{~Hz}, 1 \mathrm{H}), 7.46-7.41(\mathrm{~m}, 2 \mathrm{H}), 5.88(\mathrm{dt}, J=9.4,5.9 \mathrm{~Hz}, 1 \mathrm{H}), 5.40$ $(\mathrm{dd}, J=9.4,1.6 \mathrm{~Hz}, 1 \mathrm{H}), 5.14(\mathrm{ddt}, J=7.1,4.2,1.6 \mathrm{~Hz}, 1 \mathrm{H}), 2.63(\mathrm{dd}, J=$ 6.0, $2.7 \mathrm{~Hz}, 2 \mathrm{H}$ ), 2.42-2.33 (m, $1 \mathrm{H}$ ), 2.21-2.08 (m, $3 \mathrm{H}), 2.00$ (t, J = 2.6 $\mathrm{Hz}, 1 \mathrm{H}), 1.79(\mathrm{~d}, J=1.4 \mathrm{~Hz}, 3 \mathrm{H}), 1.67(\mathrm{~s}, 3 \mathrm{H}), 1.61(\mathrm{~s}, 3 \mathrm{H})$.

${ }^{13} \mathrm{C}$ NMR $\left(126 \mathrm{MHz}, \mathrm{CDCl}_{3}\right): \delta=165.8,142.7,133.0,132.3,130.7$, 129.8 (2 C), 128.4 (2 C), 123.9, 122.6, 80.0, 70.4, 69.3, 32.9, 26.7, 25.8, 25.5, 23.6, 17.8 .

HRMS (ESI+): $m / z[\mathrm{M}+\mathrm{Na}]^{+}$calcd for $\mathrm{C}_{20} \mathrm{H}_{24} \mathrm{O}_{2} \mathrm{Na}$ : 319.1669; found: 319.1673 .

\section{Preparation of the TBS Ether of S1 (S2b)}

In a dry round-bottom flask under argon, $\mathbf{S 1}$ (1 equiv) was dissolved in $\mathrm{CH}_{2} \mathrm{Cl}_{2}$ (0.3-0.6 $\mathrm{M}$ solution) and the solution was cooled to $0{ }^{\circ} \mathrm{C}$. Imidazole (1.8-2 equiv) and DMAP (ca. 1-5 mol\%) were added followed by the addition of TBSCl (1.5 equiv) [solid or as a solution in $\mathrm{CH}_{2} \mathrm{Cl}_{2}(3.78 \mathrm{M})$ ]. The mixture was then allowed to warm to $25^{\circ} \mathrm{C}$ and stirred for 2-6 h after which time TLC indicated full conversion of $\mathbf{S 1}$. The suspension was poured on brine ( 3 volumes of $\mathrm{CH}_{2} \mathrm{Cl}_{2}$ ) and the organic layer collected. The aq layer was re-extracted with $\mathrm{CH}_{2} \mathrm{Cl}_{2}$ ( $2 \times 1 / 2$ volume brine). The combined organic extracts were washed with brine ( $1 / 2$ initial volume brine), the washed organic phase dried over $\mathrm{Na}_{2} \mathrm{SO}_{4}$ or $\mathrm{MgSO}_{4}$ and the filtrate concentrated. The crude material was purified by column chromatography on silica gel eluting with pentane/Et ${ }_{2} \mathrm{O}$ (100:0 to 95:5) or cyclohexane/EtOAc (95:5) to afford the pure TBS ether. 
(E)-tert-Butyl[(6,10-dimethylundeca-5,9-dien-1-yn-4-yl)oxy]dimethylsilane $[(E)-S 2 b]$

Prepared on $1.5 \mathrm{~g}$ scale from $(E)-\mathbf{S 1}$; the product was isolated as a pale yellow oil (2.24 g, 93\%).

${ }^{1} \mathrm{H}$ NMR $\left(500 \mathrm{MHz}, \mathrm{CDCl}_{3}\right): \delta=5.16(\mathrm{dq}, J=8.7,1.4 \mathrm{~Hz}, 1 \mathrm{H}), 5.10$ (ddq, $J=8.4,5.6,1.4 \mathrm{~Hz}, 1 \mathrm{H}), 4.53(\mathrm{dt}, J=8.7,6.4 \mathrm{~Hz}, 1 \mathrm{H}), 2.38$ (ddd, $J=$ 16.5, 6.6, $2.7 \mathrm{~Hz}, 1 \mathrm{H}$ ), 2.27 (ddd, $J=16.5,6.3,2.7 \mathrm{~Hz}, 1 \mathrm{H}$ ), 2.09 (app q, $J=7.3 \mathrm{~Hz}, 2 \mathrm{H}), 2.03-1.98(\mathrm{~m}, 2 \mathrm{H}), 1.92(\mathrm{t}, J=2.7 \mathrm{~Hz}, 1 \mathrm{H}), 1.67(\mathrm{~s}, 3$ $\mathrm{H}), 1.66(\mathrm{~d}, J=1.3 \mathrm{~Hz}, 3 \mathrm{H}), 1.60(\mathrm{~s}, 3 \mathrm{H}), 0.88(\mathrm{~s}, 9 \mathrm{H}), 0.06(\mathrm{~s}, 3 \mathrm{H}), 0.04$ (s, $3 \mathrm{H})$.

${ }^{13} \mathrm{C}$ NMR $\left(126 \mathrm{MHz}, \mathrm{CDCl}_{3}\right): \delta=136.4,131.7,128.0,124.2,82.0,69.3$, 68.6, 39.6, 28.7, 26.4, 26.0 (3 C), 25.8, 18.4, 17.8, 16.9, -4.2, -4.6.

HRMS (ESI+): $m / z[\mathrm{M}+\mathrm{Na}]^{+}$calcd for $\mathrm{C}_{19} \mathrm{H}_{34} \mathrm{OSiNa}$ : 329.2271 ; found: 329.2270 .

\section{(Z)-tert-Butyl[(6,10-dimethylundeca-5,9-dien-1-yn-4-yl)oxy]di- methylsilane $[(Z)-S 2 b]$}

Prepared on $2.5 \mathrm{~g}$ scale from $(Z)-\mathbf{S 1}$; the product was isolated as a pale yellow oil (3.20 g, 83\%).

${ }^{1} \mathrm{H}$ NMR $\left(400 \mathrm{MHz}, \mathrm{CDCl}_{3}\right): \delta=5.16($ app d, $J=8.7 \mathrm{~Hz}, 1 \mathrm{H}$ ), 5.11 (app tdd, $J=5.1,2.8,1.4 \mathrm{~Hz}, 1 \mathrm{H}$ ), 4.53 (ddd, $J=8.8,6.7,5.9 \mathrm{~Hz}, 1 \mathrm{H}$ ), 2.37 (ddd, $J=16.5,6.7,2.6 \mathrm{~Hz}, 1 \mathrm{H}$ ), 2.26 (ddd, $J=16.5,5.9,2.7 \mathrm{~Hz}, 1 \mathrm{H}$ ), 2.19-1.96 (m, $4 \mathrm{H}), 1.93(\mathrm{t}, J=2.6 \mathrm{~Hz}, 1 \mathrm{H}), 1.71(\mathrm{~d}, J=1.4 \mathrm{~Hz}, 3 \mathrm{H})$, 1.69 (s, $3 \mathrm{H}), 1.62(\mathrm{~s}, 3 \mathrm{H}), 0.88(\mathrm{~s}, 9 \mathrm{H}), 0.07$ (s, $3 \mathrm{H}), 0.03$ (s, $3 \mathrm{H})$.

${ }^{13} \mathrm{C}$ NMR $\left(101 \mathrm{MHz}, \mathrm{CDCl}_{3}\right): \delta=136.6,132.1,128.7,124.2,82.1,69.4$, 68.2, 32.7, 29.0, 26.7, 26.0 (3 C), 25.8, 23.2, 18.3, 17.8, -4.1, -4.5.

HRMS (ESI+): $m / z[\mathrm{M}+\mathrm{Na}]^{+}$calcd for $\mathrm{C}_{19} \mathrm{H}_{34} \mathrm{OSiNa}$ : 329.2271; found: 329.2268 .

\section{Preparation of the TES Ether of S1 (S2c)}

In a dry round-bottom flask under argon, $\mathbf{S 1}$ (1 equiv) was dissolved in $\mathrm{CH}_{2} \mathrm{Cl}_{2}(0.3 \mathrm{M}$ solution $)$ and the solution was cooled to $0{ }^{\circ} \mathrm{C}$. Imidazole ( 2 equiv) and DMAP ( 1.11 equiv) were added followed by the addition of TESCl (1.5 equiv). The mixture was then allowed to warm to $25^{\circ} \mathrm{C}$ and stirred for $1 \mathrm{~h}$ after which time TLC indicated full conversion of $\mathbf{S 1}$. The suspension was poured on brine ( 3 volumes of $\mathrm{CH}_{2} \mathrm{Cl}_{2}$ ) and the organic layer collected. The aq layer was re-extracted with $\mathrm{CH}_{2} \mathrm{Cl}_{2}(2 \times 1 / 2$ volume brine). The combined organic extracts were washed with brine (1/2 initial volume brine), the washed organic layer dried over $\mathrm{MgSO}_{4}$ and the filtrate concentrated. The crude material was purified by column chromatography on silica gel eluting with pentane/ $\mathrm{Et}_{2} \mathrm{O}(90: 10)$.

\section{(E)-[(6,10-Dimethylundeca-5,9-dien-1-yn-4-yl)oxy]triethylsilane [(E)-S2c]}

Prepared on $\mathbf{5 7 9} \mathrm{mg}$ scale from (E)-S1; the product was isolated as a pale yellow oil ( $795 \mathrm{mg}, 87 \%)$.

${ }^{1} \mathrm{H} \mathrm{NMR}\left(500 \mathrm{MHz}, \mathrm{CDCl}_{3}\right): \delta=5.19(\mathrm{dq}, J=8.7,1.3 \mathrm{~Hz}, 1 \mathrm{H}), 5.10$ (ddq, $J=8.4,5.7,1.4 \mathrm{~Hz}, 1 \mathrm{H}), 4.53(\mathrm{dt}, J=8.7,6.4 \mathrm{~Hz}, 1 \mathrm{H}), 2.41$ (ddd, $J=$ $16.5,6.2,2.7 \mathrm{~Hz}, 1 \mathrm{H}$ ), 2.29 (ddd, $J=16.5,6.6,2.7 \mathrm{~Hz}, 1 \mathrm{H}$ ), 2.13-2.06 $(\mathrm{m}, 2 \mathrm{H}), 2.03-1.98(\mathrm{~m}, 2 \mathrm{H}), 1.92(\mathrm{t}, J=2.6 \mathrm{~Hz}, 1 \mathrm{H}), 1.68-1.66(\mathrm{~m}, 6$ $\mathrm{H}), 1.60(\mathrm{~s}, 3 \mathrm{H}), 0.95(\mathrm{t}, J=7.9 \mathrm{~Hz}, 9 \mathrm{H}), 0.59(\mathrm{q}, J=7.9 \mathrm{~Hz}, 6 \mathrm{H})$.

${ }^{13} \mathrm{C}$ NMR $\left(126 \mathrm{MHz}, \mathrm{CDCl}_{3}\right)$ : $\delta=136.7,131.7,127.8,124.2,81.8,69.4$, 68.2, 39.7, 28.8, 26.4, 25.8, 17.8, 16.9, 6.9 (3 C), 5.0 (3 C).

HRMS (ESI+): $m / z[M+N a]^{+}$calcd for $\mathrm{C}_{19} \mathrm{H}_{34} \mathrm{OSiNa}$ : 329.2271; found: 329.2272 .

\section{Preparation of the MOM Ether of S1 (S2d)}

In a dry round-bottom flask under argon, $\mathbf{S} \mathbf{1}$ (1 equiv) was dissolved in $\mathrm{CH}_{2} \mathrm{Cl}_{2}$ (0.3 M solution) and the solution was cooled to $0{ }^{\circ} \mathrm{C} . \mathrm{N}, \mathrm{N}-$ Diisopropylethylamine ( 3 equiv) was added followed by the addition of $\mathrm{MOMCl}$ (3 equiv). The mixture was then allowed to warm to $25^{\circ} \mathrm{C}$ and stirred for $2 \mathrm{~h}$ after which time TLC indicated full conversion of S1. The suspension was poured on brine ( 3 volumes of $\mathrm{CH}_{2} \mathrm{Cl}_{2}$ ) and the organic layer collected. The aq layer was re-extracted with $\mathrm{CH}_{2} \mathrm{Cl}_{2}$ $(2 \times 1 / 2$ volume brine). The combined organic extracts were washed with brine (1/2 initial volume brine), the washed organic phase dried over $\mathrm{MgSO}_{4}$ and the filtrate concentrated. The crude material was purified by column chromatography on silica gel eluting with pentane/ $\mathrm{Et}_{2} \mathrm{O}$ (9:1 to 8:2).

\section{(E)-4-(Methoxymethoxy)-6,10-dimethylundeca-5,9-dien-1-yne [(E)-S2d]}

Prepared on $\mathbf{5 7 9} \mathrm{mg}$ scale from (E)-S1; the product was isolated as a pale yellow oil (657 mg, 93\%).

${ }^{1} \mathrm{H}$ NMR $\left(400 \mathrm{MHz}, \mathrm{CDCl}_{3}\right): \delta=5.13-5.04(\mathrm{~m}, 2 \mathrm{H}), 4.67(\mathrm{~d}, J=6.7 \mathrm{~Hz}, 1$ H), 4.55-4.47 (m, $2 \mathrm{H}$ ), 3.39 (s, $3 \mathrm{H}$ ), 2.48 (ddd, $J=16.7,6.5,2.6 \mathrm{~Hz}, 1$ H), 2.41 (ddd, $J=16.7,5.9,2.7 \mathrm{~Hz}, 1 \mathrm{H}$ ), 2.15-2.02 (m, $4 \mathrm{H}), 1.98$ (t, $J=$ $2.6 \mathrm{~Hz}, 1 \mathrm{H}), 1.70(\mathrm{~d}, J=1.4 \mathrm{~Hz}, 3 \mathrm{H}), 1.67($ app d, $J=1.4 \mathrm{~Hz}, 3 \mathrm{H}), 1.60$ (s, $3 \mathrm{H})$.

${ }^{13} \mathrm{C}$ NMR $\left(101 \mathrm{MHz}, \mathrm{CDCl}_{3}\right): \delta=141.7,131.9,124.0,123.6,93.4,81.3$, 69.9, 69.6, 55.5, 39.8, 26.4, 25.9, 25.8, 17.8, 16.8 .

HRMS (ESI+): $m / z[\mathrm{M}+\mathrm{Na}]^{+}$calcd for $\mathrm{C}_{15} \mathrm{H}_{24} \mathrm{O}_{2} \mathrm{Na}$ : 259.1669; found: 259.1668 .

\section{Preparation of Aldehydes 7 from S2; General Procedure}

In a dry round-bottom flask under argon, AD-mix- $\alpha$ ( $1.4 \mathrm{~g}$ per mmol of S2) and methylsulfonamide (1 equiv) were dissolved in $t$ $\mathrm{BuOH} / \mathrm{H}_{2} \mathrm{O}(1: 1)$ (15 $\mathrm{mL}$ per $\mathrm{mmol}$ of $\left.\mathbf{S 2}\right)$ and the solution was cooled to $0{ }^{\circ} \mathrm{C}$. S2 (1 equiv) was added slowly as a solution in $t-\mathrm{BuOH}(0.5 \mathrm{~mL}$ per mmol). The mixture was stirred at $0{ }^{\circ} \mathrm{C}$ for $5 \mathrm{~min}$ then allowed to warm to $25^{\circ} \mathrm{C}$ and stirred for $16 \mathrm{~h}$. TLC indicated full conversion of S2 into the diol. The suspension was quenched by addition of a sat. solution of $\mathrm{Na}_{2} \mathrm{SO}_{3}\left(15 \mathrm{~mL}\right.$ per mmol) and then solid $\mathrm{Na}_{2} \mathrm{SO}_{3}$ (2 g per $\mathrm{mmol}$ ). The resulting mixture was stirred at $25^{\circ} \mathrm{C}$ for $1 \mathrm{~h}$, then poured on brine ( 5 volumes of $t-\mathrm{BuOH})$ and extracted with EtOAc ( $4 \times$ volume $t$-BuOH). The combined organic extracts were washed with a sat. solution of $\mathrm{Na}_{2} \mathrm{SO}_{3}$ ( $15 \mathrm{~mL}$ per mmol) $(2 \times$ volume $t-\mathrm{BuOH})$ and a sat. solution of $\mathrm{NaHCO}_{3}$ (volume $t-\mathrm{BuOH}$ ). The washed organic extracts were dried over $\mathrm{Na}_{2} \mathrm{SO}_{4}$ and the filtrate concentrated. The crude diol was redissolved in HPLC grade $\mathrm{CH}_{2} \mathrm{Cl}_{2}(20 \mathrm{~mL}$ per mmol $)$ and the solution cooled to $0{ }^{\circ} \mathrm{C}$ and $\mathrm{NaIO}_{4} @ \mathrm{SiO}_{2}{ }^{17}(2 \mathrm{~g}$ per mmol) was added. The suspension was stirred at $25^{\circ} \mathrm{C}$ for $1.5-3 \mathrm{~h}$ after which time TLC indicated full conversion of the diol. The solids were filtered off on a pad of Celite and washed with $\mathrm{Et}_{2} \mathrm{O}(3 \times 10 \mathrm{~mL}$ per mmol) and the filtrate concentrated. The resulting crude aldehyde was purified by column chromatography on silica gel eluting with pentane/ $\mathrm{Et}_{2} \mathrm{O}$ (98:2 to 9:1) or cyclohexane/EtOAc (90:10 to 80:20) to afford the pure aldehyde.

(E)-6-Methyl-9-oxonon-5-en-1-yn-4-yl Benzoate [(E)-7a]

Prepared on $2.63 \mathrm{~g}$ scale from $(E)-\mathbf{S 2 a}$; the product was isolated as a pale yellow oil ( $1.59 \mathrm{~g}, 66 \%)$.

${ }^{1} \mathrm{H}$ NMR $\left(400 \mathrm{MHz}, \mathrm{CDCl}_{3}\right): \delta=9.77(\mathrm{t}, J=1.7 \mathrm{~Hz}, 1 \mathrm{H}), 8.07-8.02(\mathrm{~m}, 2$ H), 7.56 (ddt, $J=8.7,6.9,1.3 \mathrm{~Hz}, 1 \mathrm{H}), 7.47-7.40(\mathrm{~m}, 2 \mathrm{H}), 5.84(\mathrm{dt}, J=$ 9.0, $6.1 \mathrm{~Hz}, 1 \mathrm{H}), 5.38$ (ddq, $J=9.1,2.7,1.4 \mathrm{~Hz}, 1 \mathrm{H}), 2.70-2.55(\mathrm{~m}, 4 \mathrm{H})$, 2.42-2.36 (m, $2 \mathrm{H}), 1.99(\mathrm{t}, J=2.7 \mathrm{~Hz}, 1 \mathrm{H}), 1.85(\mathrm{~d}, J=1.3 \mathrm{~Hz}, 3 \mathrm{H})$. 
${ }^{13} \mathrm{C}$ NMR $\left(101 \mathrm{MHz}, \mathrm{CDCl}_{3}\right): \delta=201.8,165.8,140.4,133.1,130.4$, 129.8 (2 C), 128.5 (2 C), 122.8, 79.5, 70.5, 69.4, 41.9, 31.7, 25.2, 17.4 .

HRMS (ESI+): $m / z[\mathrm{M}+\mathrm{MeOH}+\mathrm{Na}]^{+}$calcd for $\mathrm{C}_{18} \mathrm{H}_{22} \mathrm{O}_{4} \mathrm{Na}: 325.1410$; found: 325.1403 .

\section{(Z)-6-Methyl-9-oxonon-5-en-1-yn-4-yl Benzoate [(Z)-7a]}

Prepared on $2.5 \mathrm{~g}$ scale from $(Z)-\mathbf{S 2 a}$; the product was isolated as a pale yellow solid ( $2.90 \mathrm{~g}, 84 \%)$.

Mp 33-35 ${ }^{\circ} \mathrm{C}\left(\mathrm{CH}_{2} \mathrm{Cl}_{2} /\right.$ pentane $)$.

${ }^{1} \mathrm{H}$ NMR $\left(500 \mathrm{MHz}, \mathrm{CDCl}_{3}\right): \delta=9.81(\mathrm{t}, J=1.2 \mathrm{~Hz}, 1 \mathrm{H}), 8.06-8.02(\mathrm{~m}, 2$ H), 7.58-7.53 (m, $1 \mathrm{H}), 7.46-7.41(\mathrm{~m}, 2 \mathrm{H}), 5.86(\mathrm{dt}, J=9.4,6.1 \mathrm{~Hz}, 1$ H), 5.38 (app dd, $J=9.4,1.5 \mathrm{~Hz}, 1 \mathrm{H}), 2.70-2.53(\mathrm{~m}, 6 \mathrm{H}), 2.01(\mathrm{t}, J=2.6$ $\mathrm{Hz}, 1 \mathrm{H}), 1.77$ (d, $J=1.4 \mathrm{~Hz}, 3 \mathrm{H})$.

${ }^{13} \mathrm{C}$ NMR $\left(126 \mathrm{MHz}, \mathrm{CDCl}_{3}\right): \delta=201.7,165.8,140.6,133.1,130.4$, 129.8 (2 C), 128.5 (2 C), 123.9, 79.7, 70.7, 69.2, 42.3, 25.3, 25.1, 23.3.

HRMS (ESI+): $m / z[\mathrm{M}+\mathrm{Na}]^{+}$calcd for $\mathrm{C}_{17} \mathrm{H}_{18} \mathrm{O}_{3} \mathrm{Na}$ : 293.1148; found: 293.1154 (also observed: $m / z[\mathrm{M}+\mathrm{MeOH}+\mathrm{Na}]$ calcd for $\mathrm{C}_{18} \mathrm{H}_{22} \mathrm{O}_{4} \mathrm{Na}$ : 325.1410; found: 325.1423 ).

\section{(E)-6-[(tert-Butyldimethylsilyl)oxy]-4-methylnon-4-en-8-ynal [(E)-7b]}

Prepared on $2.24 \mathrm{~g}$ scale from $(E)-\mathbf{S 2} \mathbf{b}$; the product was isolated as a pale yellow oil $(1.314 \mathrm{~g}, 64 \%)$.

${ }^{1} \mathrm{H} \mathrm{NMR}\left(400 \mathrm{MHz}, \mathrm{CDCl}_{3}\right): \delta=9.78(\mathrm{t}, J=1.8 \mathrm{~Hz}, 1 \mathrm{H}), 5.19(\mathrm{dq}, J=8.7$, $1.3 \mathrm{~Hz}, 1 \mathrm{H}), 4.52(\mathrm{dt}, J=8.6,6.5 \mathrm{~Hz}, 1 \mathrm{H}), 2.58-2.51(\mathrm{~m}, 2 \mathrm{H}), 2.43-$ $2.31(\mathrm{~m}, 3 \mathrm{H}), 2.27$ (ddd, $J=16.5,6.7,2.7 \mathrm{~Hz}, 1 \mathrm{H}), 1.92(\mathrm{t}, J=2.7 \mathrm{~Hz}, 1$ $\mathrm{H}), 1.69(\mathrm{~d}, J=1.4 \mathrm{~Hz}, 3 \mathrm{H}), 0.87(\mathrm{~s}, 9 \mathrm{H}), 0.06(\mathrm{~s}, 3 \mathrm{H}), 0.02(\mathrm{~s}, 3 \mathrm{H})$.

${ }^{13} \mathrm{C}$ NMR $\left(101 \mathrm{MHz}, \mathrm{CDCl}_{3}\right): \delta=202.1,134.7,128.8,81.6,69.6,68.4$, 42.0, 31.7, 28.6, 25.9 (3 C), 18.3, 17.1, -4.3, -4.6.

HRMS (ESI+): $m / z[\mathrm{M}+\mathrm{Na}]^{+}$calcd for $\mathrm{C}_{16} \mathrm{H}_{28} \mathrm{O}_{2} \mathrm{SiNa}$ : 303.1751 ; found: 303.1744.

\section{(Z)-6-[(tert-Butyldimethylsilyl)oxy]-4-methylnon-4-en-8-ynal [(Z)-7b]}

Prepared on $3.0 \mathrm{~g}$ scale from $(Z)-\mathbf{S 2 b}$; the product was isolated as a pale yellow oil $(2.40 \mathrm{~g}, 87 \%)$.

${ }^{1} \mathrm{H}$ NMR $\left(500 \mathrm{MHz}, \mathrm{CDCl}_{3}\right): \delta=9.80(\mathrm{t}, J=1.5 \mathrm{~Hz}, 1 \mathrm{H}), 5.20$ (app dd, $J=$ $8.8,1.4 \mathrm{~Hz}, 1 \mathrm{H}), 4.52$ (ddd, $J=8.9,6.9,6.0 \mathrm{~Hz}, 1 \mathrm{H}), 2.58-2.53(\mathrm{~m}, 2 \mathrm{H}$ ), 2.51-2.44 (m, $1 \mathrm{H}), 2.40$ (ddd, $J=16.5,6.0,2.7 \mathrm{~Hz}, 1 \mathrm{H}), 2.35-2.24(\mathrm{~m}$, $2 \mathrm{H}), 1.93(\mathrm{t}, J=2.6 \mathrm{~Hz}, 1 \mathrm{H}), 1.70(\mathrm{~d}, J=1.4 \mathrm{~Hz}, 3 \mathrm{H}), 0.86(\mathrm{~s}, 9 \mathrm{H}), 0.06$ (s, $3 \mathrm{H}), 0.02(\mathrm{~s}, 3 \mathrm{H})$.

${ }^{13} \mathrm{C}$ NMR $\left(126 \mathrm{MHz}, \mathrm{CDCl}_{3}\right): \delta=201.7,134.6,129.9,81.8,69.8,68.0$, 42.5, 28.9, 25.9 (3 C), 24.7, 23.0, 18.3, $-4.2,-4.5$.

HRMS (ESI+): $m / z[\mathrm{M}+\mathrm{Na}]^{+}$calcd for $\mathrm{C}_{16} \mathrm{H}_{28} \mathrm{O}_{2} \mathrm{SiNa}$ : 303.1751 ; found: 303.1752 (also observed: $m / z$ [M $+\mathrm{MeOH}+\mathrm{Na}$ ] calcd for $\mathrm{C}_{17} \mathrm{H}_{32} \mathrm{O}_{3} \mathrm{SiNa}$ : 335.2013; found: 335.2025).

\section{(E)-4-Methyl-6-[(triethylsilyl)oxy]non-4-en-8-ynal [(E)-71]}

Prepared on $790 \mathrm{mg}$ scale from $(E)-\mathbf{S 2 c}$; the product was isolated as a pale yellow oil (506 mg, 70\%).

${ }^{1} \mathrm{H}$ NMR $\left(500 \mathrm{MHz}, \mathrm{CDCl}_{3}\right): \delta=9.78(\mathrm{t}, J=1.7 \mathrm{~Hz}, 1 \mathrm{H}), 5.24-5.19(\mathrm{~m}, 1$ $\mathrm{H}$ ), 4.53 (ddd, $J=8.7,7.0,5.9 \mathrm{~Hz}, 1 \mathrm{H}$ ), 2.55 (ddd, $J=8.0,6.9,1.6 \mathrm{~Hz}, 2$ H), 2.41 (ddd, $J=16.4,5.9,2.6 \mathrm{~Hz}, 1 \mathrm{H}), 2.36-2.32(\mathrm{~m}, 2 \mathrm{H}), 2.29$ (ddd, $J=16.5,7.1,2.7 \mathrm{~Hz}, 1 \mathrm{H}), 1.92(\mathrm{t}, J=2.7 \mathrm{~Hz}, 1 \mathrm{H}), 1.70$ (d, $J=1.3 \mathrm{~Hz}, 3$ $\mathrm{H}), 0.94(\mathrm{t}, J=7.9 \mathrm{~Hz}, 9 \mathrm{H}), 0.58(\mathrm{q}, J=7.7 \mathrm{~Hz}, 6 \mathrm{H})$.

${ }^{13} \mathrm{C}$ NMR $\left(126 \mathrm{MHz}, \mathrm{CDCl}_{3}\right): \delta=202.1,134.9,128.7,81.4,69.6,68.0$, 42.0, 31.7, 28.7, 17.2, 6.9 (3 C), 5.0 (3 C).
HRMS (ESI+): $m / z$ [M + Na] calcd for $\mathrm{C}_{16} \mathrm{H}_{28} \mathrm{O}_{2} \mathrm{SiNa}$ : 303.1751; found: 303.1756.

(E)-6-(Methoxymethoxy)-4-methylnon-4-en-8-ynal [(E)-7k]

Prepared on $650 \mathrm{mg}$ scale from $(E)-\mathbf{S 2 d}$; the product was isolated as a pale yellow oil (385 mg, 57\%).

${ }^{1} \mathrm{H}$ NMR $\left(400 \mathrm{MHz}, \mathrm{CDCl}_{3}\right): \delta=9.77(\mathrm{t}, J=1.7 \mathrm{~Hz}, 1 \mathrm{H}), 5.17-5.12(\mathrm{~m}, 1$ $\mathrm{H}), 4.62(\mathrm{~d}, J=6.8 \mathrm{~Hz}, 1 \mathrm{H}), 4.55-4.46(\mathrm{~m}, 2 \mathrm{H}), 3.38(\mathrm{~s}, 3 \mathrm{H}), 2.60-2.53$ (m, $2 \mathrm{H}$ ), 2.47 (ddd, $J=16.7,6.2,2.7 \mathrm{~Hz}, 1 \mathrm{H}), 2.44-2.35$ (m, $3 \mathrm{H}), 1.98$ (t, $J=2.6 \mathrm{~Hz}, 1 \mathrm{H}), 1.73(\mathrm{~d}, J=1.4 \mathrm{~Hz}, 3 \mathrm{H})$.

${ }^{13} \mathrm{C}$ NMR $\left(101 \mathrm{MHz}, \mathrm{CDCl}_{3}\right): \delta=201.9,139.6,124.5,93.6,80.9,69.8$, 69.8, 55.5, 42.0, 31.8, 25.7, 17.1 .

HRMS (ESI+): $m / z[\mathrm{M}+\mathrm{Na}]^{+}$calcd for $\mathrm{C}_{12} \mathrm{H}_{18} \mathrm{O}_{3} \mathrm{Na}$ : 233.1148; found: 233.1158.

\section{Ketones 7c-j; General Procedure}

Depending on the polarity of the alcohol intermediate $\mathbf{S 3}$ (and the ease of purification), one of the two following methods was used for the preparation of ketones $\mathbf{7 c}-\mathbf{j}$.

\section{Method A}

In a dry flask under argon, the corresponding aldehyde $\mathbf{7 a , b}$ (1 equiv) was dissolved in anhydrous THF (ca. $4 \mathrm{~mL}$ per mmol) and the solution was cooled to $-78{ }^{\circ} \mathrm{C}$. A solution of Grignard reagent $\mathrm{R}-\mathrm{MgX}(1.5$ equiv) was added slowly at $-78{ }^{\circ} \mathrm{C}$. The mixture was stirred at $-78{ }^{\circ} \mathrm{C}$ for $1.5-3 \mathrm{~h}$ during which time a milky suspension was observed. The suspension was quenched by addition of a sat. aq solution of $\mathrm{NH}_{4} \mathrm{Cl}$ (ca. $5 \mathrm{~mL}$ per mmol) at $-78{ }^{\circ} \mathrm{C}$, then allowed to warm to $25^{\circ} \mathrm{C}$ whilst stirring vigorously. It was then poured on brine $(70 \mathrm{~mL}$ per $\mathrm{mmol})$ and extracted with $\mathrm{Et}_{2} \mathrm{O}(3 \times 40 \mathrm{~mL}$ per $\mathrm{mmol})$. The combined ethereal extracts were dried over $\mathrm{Na}_{2} \mathrm{SO}_{4}$ and the filtrate concentrated. The crude material was purified by column chromatography on silica gel eluting with cyclohexane/EtOAc to afford the alcohol as a mixture of diastereomers (the unreacted aldehyde can be recovered and recycled at this stage).

The pure alcohol was redissolved in $\mathrm{CH}_{2} \mathrm{Cl}_{2}$ (ca. $10 \mathrm{~mL}$ per mmol) and the solution cooled to $0{ }^{\circ} \mathrm{C}$ and $\mathrm{NaHCO}_{3}$ (5 equiv) and Dess-Martin periodinane (1.2 equiv) were added sequentially. The mixture was stirred at $0{ }^{\circ} \mathrm{C}$ for $1-2 \mathrm{~h}$ and then at $25^{\circ} \mathrm{C}$ for $1-2 \mathrm{~h}$ after which time TLC showed full conversion of the alcohol into the less polar ketone. The mixture was either quenched by addition of a sat. solution of $\mathrm{Na}_{2} \mathrm{~S}_{2} \mathrm{O}_{3}$ and extracted with $\mathrm{CH}_{2} \mathrm{Cl}_{2}$ or diluted with pentane (2$3 \times$ volume $\mathrm{CH}_{2} \mathrm{Cl}_{2}$ ) and filtered. The resulting crude product was purified by chromatography on silica gel eluting with cyclohexane/EtOAc to afford the title ketone.

\section{Method B}

In a dry flask under argon, the corresponding aldehyde $\mathbf{7 a}, \mathbf{b}$ (1 equiv) was dissolved in anhydrous THF (ca. $4 \mathrm{~mL}$ per mmol) and the solution was cooled to $-78^{\circ} \mathrm{C}$. A solution of Grignard reagent R-MgX (1.5 equiv) was added slowly at $-78{ }^{\circ} \mathrm{C}$. The mixture was stirred at $-78{ }^{\circ} \mathrm{C}$ for 1.5-3 h during which time a milky suspension was observed. The suspension was quenched by addition of a sat. aq solution of $\mathrm{NH}_{4} \mathrm{Cl}$ (ca. $5 \mathrm{~mL}$ per mmol) at $-78{ }^{\circ} \mathrm{C}$, then allowed to warm to $25^{\circ} \mathrm{C}$ whilst stirring vigorously. It was then poured on brine $(70 \mathrm{~mL}$ per mmol) and extracted with $\mathrm{Et}_{2} \mathrm{O}(3 \times 40 \mathrm{~mL}$ per $\mathrm{mmol})$. The combined ethereal extracts were dried over $\mathrm{Na}_{2} \mathrm{SO}_{4}$ and the filtrate concentrated. The crude alcohol (containing the unreacted starting aldehyde) was redissolved in $\mathrm{CH}_{2} \mathrm{Cl}_{2}$ (ca. $10 \mathrm{~mL}$ per mmol) and the solution cooled to $0{ }^{\circ} \mathrm{C}$ and $\mathrm{NaHCO}_{3}$ (5 equiv) and Dess-Martin periodinane (1.2 equiv) were 
added sequentially. The mixture was stirred at $0{ }^{\circ} \mathrm{C}$ for $1-2 \mathrm{~h}$ and then at $25^{\circ} \mathrm{C}$ for $1-2 \mathrm{~h}$ after which time TLC showed full conversion of the alcohol into the less polar ketone. The mixture was either quenched by addition of a sat. solution of $\mathrm{Na}_{2} \mathrm{~S}_{2} \mathrm{O}_{3}$ and extracted with $\mathrm{CH}_{2} \mathrm{Cl}_{2}$ or diluted with pentane $\left(2-3 \times\right.$ volume $\left.\mathrm{CH}_{2} \mathrm{Cl}_{2}\right)$ and filtered. The resulting crude product was purified by chromatography on silica gel eluting with cyclohexane/EtOAc to afford the title ketone (the unreacted aldehyde can be recovered and recycled).

\section{(E)-9-Hydroxy-6-methyldec-5-en-1-yn-4-yl Benzoate [(E)-S3c]}

Prepared on $300 \mathrm{mg}$ scale from (E)-7a according to method A and using a commercial solution of $\mathrm{MeMgBr}$ in $\mathrm{Et}_{2} \mathrm{O}(3 \mathrm{M})$. The product was purified by silica gel column chromatography eluting with cyclohexane/EtOAc ( $4: 1$ to 3:1) and obtained as a colorless oil ( $221 \mathrm{mg}, 70 \%$, ca. 1:1 dr). Note: in the proton assignments below ' $1 \mathrm{H}+1 \mathrm{H}$ ' refers to a signal accounting for one proton of each diastereomer; likewise, ' $1 \mathrm{C}+$ $1 \mathrm{C}$ ' refers to a signal accounting for one carbon of each diastereomer.

${ }^{1} \mathrm{H}$ NMR $\left(400 \mathrm{MHz}, \mathrm{CDCl}_{3}\right): \delta=8.07-8.02(\mathrm{~m}, 2 \mathrm{H}+2 \mathrm{H}), 7.58-7.52(\mathrm{~m}$, $1 \mathrm{H}+1 \mathrm{H}), 7.47-7.40(\mathrm{~m}, 2 \mathrm{H}+2 \mathrm{H}), 5.89-5.81(\mathrm{~m}, 1 \mathrm{H}+1 \mathrm{H}), 5.39$ (app d quin, $J=9.0,1.4 \mathrm{~Hz}, 1 \mathrm{H}+1 \mathrm{H}$ ), 3.80 (app sept, $J=5.7 \mathrm{~Hz}, 1 \mathrm{H}+$ $1 \mathrm{H}), 2.71-2.56(\mathrm{~m}, 2 \mathrm{H}+2 \mathrm{H}), 2.24-2.06(\mathrm{~m}, 2 \mathrm{H}+2 \mathrm{H}), 1.99$ and 1.99 (two t, $J=2.5 \mathrm{~Hz}, 1 \mathrm{H}+1 \mathrm{H}), 1.84(\mathrm{~s}, 3 \mathrm{H}+3 \mathrm{H}), 1.63-1.55(\mathrm{~m}, 2 \mathrm{H}+2$ $\mathrm{H}), 1.20(\mathrm{~d}, J=6.2 \mathrm{~Hz}, 3 \mathrm{H}+3 \mathrm{H})$.

${ }^{13} \mathrm{C} \mathrm{NMR}\left(101 \mathrm{MHz}, \mathrm{CDCl}_{3}\right): \delta=165.9,165.9,142.4(1 \mathrm{C}+1 \mathrm{C}), 133.0(1$ C + 1 C), $130.7(1 \mathrm{C}+1 \mathrm{C}), 129.8(2 \mathrm{C}+2 \mathrm{C}), 128.5(2 \mathrm{C}+2 \mathrm{C}), 122.3$, 122.3, 79.8, 79.8, 70.4, 70.4, 69.7, 69.7, 68.0, 67.9, 37.2, 37.2, 36.1, $36.0,25.3(1 \mathrm{C}+1 \mathrm{C}), 23.7,23.7,17.2(1 \mathrm{C}+1 \mathrm{C})$.

HRMS (ESI+): $m / z$ [M $+\mathrm{Na}]^{+}$calcd for $\mathrm{C}_{18} \mathrm{H}_{22} \mathrm{O}_{3} \mathrm{Na}$ : 309.1461; found: 309.1457.

\section{(E)-6-Methyl-9-oxodec-5-en-1-yn-4-yl Benzoate [(E)-7c)]}

Prepared on $221 \mathrm{mg}$ scale from S3c according to method A. The product was purified by silica gel column chromatography eluting with cyclohexane/EtOAc (9:1 to 4:1) to afford a colorless oil (186 mg, 85\%); $60 \%$ yield over 2 steps.

${ }^{1} \mathrm{H}$ NMR (400 MHz, $\mathrm{CDCl}_{3}$ ): $\delta=8.06-8.02(\mathrm{~m}, 2 \mathrm{H}$ ), 7.55 (ddt, $J=8.0$, 6.9, $1.4 \mathrm{~Hz}, 1 \mathrm{H}), 7.48-7.40(\mathrm{~m}, 2 \mathrm{H}), 5.84(\mathrm{dt}, J=9.0,6.1 \mathrm{~Hz}, 1 \mathrm{H})$, 5.38-5.32 (m, $1 \mathrm{H}), 2.69-2.53$ ( $\mathrm{m}, 4 \mathrm{H}), 2.36-2.29$ (m, $2 \mathrm{H}), 2.15$ (s, 3 $\mathrm{H}), 1.99(\mathrm{t}, J=2.6 \mathrm{~Hz}, 1 \mathrm{H}), 1.83(\mathrm{~d}, J=1.4 \mathrm{~Hz}, 3 \mathrm{H})$.

${ }^{13} \mathrm{C}$ NMR $\left(101 \mathrm{MHz}, \mathrm{CDCl}_{3}\right): \delta=208.1,165.8,141.0,133.1,130.5$, 129.8 (2 C), 128.5 (2 C), 122.4, 79.7, 70.4, 69.5, 41.9, 33.4, 30.1, 25.2, 17.4 .

HRMS (ESI+): $m / z$ [M + Na] ${ }^{+}$calcd for $\mathrm{C}_{18} \mathrm{H}_{20} \mathrm{O}_{3} \mathrm{Na}$ : 307.1305; found: 307.1306.

\section{(Z)-9-Hydroxy-6-methyldec-5-en-1-yn-4-yl Benzoate [(Z)-S3c]}

Prepared on $300 \mathrm{mg}$ scale from (Z)-7a according to method $A$ and using a commercial solution of $\mathrm{MeMgBr}$ in $\mathrm{Et}_{2} \mathrm{O}(3 \mathrm{M})$. The product was purified by silica gel column chromatography eluting with cyclohexane/EtOAc (85:15 to 7:3) and obtained as a colorless oil (208 mg, 65\%, ca. $1.15: 1 \mathrm{dr} ; 80 \%$ based on recovered starting material) (plus $55 \mathrm{mg}$ recovered aldehyde, $18 \%$ ).

${ }^{1} \mathrm{H}$ NMR $\left(500 \mathrm{MHz}, \mathrm{CDCl}_{3}\right): \delta=8.07-8.03(\mathrm{~m}, 2 \mathrm{H}$ major $+2 \mathrm{H}$ minor $)$, 7.58-7.52 (m, $1 \mathrm{H}$ major + $1 \mathrm{H}$ minor), 7.46-7.40 (m, $2 \mathrm{H}$ major $+2 \mathrm{H}$ minor), 5.92 (app dt, $J=9.3,6.1 \mathrm{~Hz}, 1 \mathrm{H}$ major + $1 \mathrm{H}$ minor), 5.38-5.32 ( $\mathrm{m}, 1 \mathrm{H}$ major $+1 \mathrm{H}$ minor), 3.84-3.73 ( $\mathrm{m}, 1 \mathrm{H}$ major $+1 \mathrm{H}$ minor $)$, 2.70-2.56 (m, $2 \mathrm{H}$ major + $2 \mathrm{H}$ minor), $2.50(\mathrm{dt}, J=13.6,8.2 \mathrm{~Hz}, 1 \mathrm{H}$ major), 2.38 (ddd, $J=13.5,10.0,5.6 \mathrm{~Hz}, 1 \mathrm{H}$ minor), 2.30 (ddd, $J=13.4$, 9.8, $6.7 \mathrm{~Hz}, 1 \mathrm{H}$ minor), 2.19 (ddd, $J=13.7,8.0,5.7 \mathrm{~Hz}, 1 \mathrm{H}$ major), 2.00 and 2.00 (two t, $J=2.6 \mathrm{~Hz}, 1 \mathrm{H}$ major $+1 \mathrm{H}$ minor), $1.78(\mathrm{~d}, J=1.4 \mathrm{~Hz}, 3$ $\mathrm{H}$ minor), 1.76 (d, $J=1.4 \mathrm{~Hz}, 3 \mathrm{H}$ major), $1.66-1.50(\mathrm{~m}, 2 \mathrm{H}$ major $+2 \mathrm{H}$ minor), 1.20 (d, $J=6.2 \mathrm{~Hz}, 3 \mathrm{H}$ minor), 1.19 (d, $J=6.2 \mathrm{~Hz}, 3 \mathrm{H}$ major).

${ }^{13} \mathrm{C}$ NMR $\left(126 \mathrm{MHz}, \mathrm{CDCl}_{3}\right): \delta=166.1,165.9,143.0,142.1,133.2$, $133.1,130.5,130.4,129.9$ (2 C one diastereomer), 129.8 (2 C one diastereomer), 128.5 (2 C one diastereomer), 128.4 (2 C one diastereomer), 123.2, 122.6, 79.9, 79.8, 70.5, 70.5, 69.7, 69.3, 68.0, 66.6, 37.7, $36.9,29.2,28.5,25.6,25.4,23.9,23.7,23.5,23.2$.

HRMS (ESI+): $m / z[\mathrm{M}+\mathrm{Na}]^{+}$calcd for $\mathrm{C}_{18} \mathrm{H}_{22} \mathrm{O}_{3} \mathrm{Na}$ : 309.1461; found: 309.1451 .

\section{(Z)-6-Methyl-9-oxodec-5-en-1-yn-4-yl Benzoate [( $Z)-7 c)]$}

Prepared on $190 \mathrm{mg}$ scale from S3c according to method A. The product was purified by silica gel column chromatography eluting with cyclohexane/EtOAc (4:1) to afford a colorless oil (179 mg, 95\%); 62\% yield over 2 steps (76\% based on recovered starting material).

${ }^{1} \mathrm{H}$ NMR $\left(400 \mathrm{MHz}, \mathrm{CDCl}_{3}\right): \delta=8.07-8.01(\mathrm{~m}, 2 \mathrm{H}), 7.58-7.51(\mathrm{~m}, 1 \mathrm{H})$, 7.47-7.39 (m, $2 \mathrm{H}), 5.85(\mathrm{dt}, J=9.3,6.1 \mathrm{~Hz}, 1 \mathrm{H}), 5.39-5.33(\mathrm{~m}, 1 \mathrm{H})$, 2.70-2.41 (m, $6 \mathrm{H}), 2.14(\mathrm{~s}, 3 \mathrm{H}), 2.00(\mathrm{t}, J=2.7 \mathrm{~Hz}, 1 \mathrm{H}), 1.74(\mathrm{~d}, J=1.5$ $\mathrm{Hz}, 3 \mathrm{H})$

${ }^{13} \mathrm{C}$ NMR $\left(101 \mathrm{MHz}, \mathrm{CDCl}_{3}\right): \delta=208.0,165.7,141.1,133.0,130.5$, 129.8 (2 C), 128.4 (2 C), 123.5, 79.8, 70.5, 69.3, 42.0, 30.0, 26.8, 25.3, 23.3.

HRMS (ESI+): $m / z$ [M + Na] calcd for $\mathrm{C}_{18} \mathrm{H}_{20} \mathrm{O}_{3} \mathrm{Na}$ : 307.1305; found: 307.1304.

\section{(E)-7-[(tert-Butyldimethylsilyl)oxy]-5-methyldec-5-en-9-yn-2-ol} [(E)-S3d]

Prepared on $500 \mathrm{mg}$ scale from $(E)-\mathbf{7 b}$ according to method A and using a commercial solution of $\mathrm{MeMgBr}$ in $\mathrm{Et}_{2} \mathrm{O}(3 \mathrm{M})$. The product was purified by silica gel column chromatography eluting with cyclohexane/EtOAc (95:5 to 9:1) and obtained as a colorless oil (470 $\mathrm{mg}, 89 \%$, ca. $1: 1 d r)$. Note: in the proton assignments below ' $1 \mathrm{H}+1 \mathrm{H}$ ' refers to a signal accounting for one proton of each diastereomer; likewise, ' $1 \mathrm{C}$ $+1 \mathrm{C}$ ' refers to a signal accounting for one carbon of each diastereomer.

${ }^{1} \mathrm{H}$ NMR (500 MHz, $\mathrm{CDCl}_{3}$ ): $\delta=5.20$ (app d quin, $J=8.6,1.3 \mathrm{~Hz}, 1 \mathrm{H}+1$ $\mathrm{H}), 4.53$ (app dt, $J=8.6,6.5 \mathrm{~Hz}, 1 \mathrm{H}+1 \mathrm{H}$ ), 3.80 (app sext $J=6.4 \mathrm{~Hz}, 1$ $\mathrm{H}+1 \mathrm{H}$ ), 2.40 (app ddd, $J=16.5,6.2,2.6 \mathrm{~Hz}, 1 \mathrm{H}+1 \mathrm{H}$ ), 2.28 (app ddd, $J=16.5,6.7,2.6 \mathrm{~Hz}, 1 \mathrm{H}+1 \mathrm{H}), 2.15-2.02(\mathrm{~m}, 2 \mathrm{H}+2 \mathrm{H}), 1.92$ and 1.91 (two t, $J=2.6 \mathrm{~Hz}, 1 \mathrm{H}+1 \mathrm{H}), 1.69(\mathrm{~d}, J=1.4 \mathrm{~Hz}, 3 \mathrm{H}$ one diastereomer) and $1.68(\mathrm{~d}, J=1.4 \mathrm{~Hz}, 3 \mathrm{H}$ other diastereomer), $1.64-1.50(\mathrm{~m}, 2 \mathrm{H}+2$ $\mathrm{H}), 1.20(\mathrm{~d}, J=0.6 \mathrm{~Hz}, 3 \mathrm{H}$ one diastereomer $)$ and $1.19(\mathrm{~d}, J=0.6 \mathrm{~Hz}, 3$ $\mathrm{H}$ other diastereomer), $0.87(\mathrm{~s}, 9 \mathrm{H}+9 \mathrm{H}), 0.06(\mathrm{~s}, 3 \mathrm{H}+3 \mathrm{H}), 0.03(\mathrm{~s}, 3$ $\mathrm{H}+3 \mathrm{H})$

${ }^{13} \mathrm{C}$ NMR $\left(126 \mathrm{MHz}, \mathrm{CDCl}_{3}\right): \delta=136.6,136.4,128.2(1 \mathrm{C}+1 \mathrm{C}), 81.8$, $81.8,69.5,69.4,68.4(1 \mathrm{C}+1 \mathrm{C}), 68.2,67.8,37.2,37.2,36.2,35.9,28.7$, 28.7, 26.0 (3C + 3C), 23.6 (1C+1C), $18.3(1 C+1 C), 17.0(1 C+1 C)$, $-4.2,-4.2,-4.6(1 \mathrm{C}+1 \mathrm{C})$.

HRMS (ESI+): $m / z[\mathrm{M}+\mathrm{Na}]^{+}$calcd for $\mathrm{C}_{17} \mathrm{H}_{32} \mathrm{O}_{2} \mathrm{SiNa}$ : 319.2064 ; found: 319.2072 .

(E)-7-[(tert-Butyldimethylsilyl)oxy]-5-methyldec-5-en-9-yn-2-one [(E)-7d)]

Prepared on $470 \mathrm{mg}$ scale from (E)-S3d according to method A. The product was purified by silica gel column chromatography eluting with cyclohexane/EtOAc (9:1) to afford a colorless oil $(338.7 \mathrm{mg}$, $73 \%) ; 65 \%$ yield over 2 steps. 
${ }^{1} \mathrm{H}$ NMR $\left(500 \mathrm{MHz}, \mathrm{CDCl}_{3}\right): \delta=5.15$ (app d sept, $\left.J=8.6,1.4 \mathrm{~Hz}, 1 \mathrm{H}\right)$, $4.51(\mathrm{dt}, J=8.6,6.5 \mathrm{~Hz}, 1 \mathrm{H}), 2.57-2.51(\mathrm{~m}, 2 \mathrm{H}), 2.38$ (ddd, $J=16.5$, 6.3, 2.6 Hz, $1 \mathrm{H}), 2.30-2.22(\mathrm{~m}, 3 \mathrm{H}), 2.15(\mathrm{~s}, 3 \mathrm{H}), 1.91(\mathrm{t}, J=2.6 \mathrm{~Hz}, 1$ H), $1.67(\mathrm{~d}, J=1.3 \mathrm{~Hz}, 3 \mathrm{H}), 0.87(\mathrm{~s}, 9 \mathrm{H}), 0.05(\mathrm{~s}, 3 \mathrm{H}), 0.02(\mathrm{~s}, 3 \mathrm{H})$.

${ }^{13} \mathrm{C}$ NMR $\left(126 \mathrm{MHz}, \mathrm{CDCl}_{3}\right): \delta=208.3,135.3,128.3,81.7,69.5,68.4$, $42.1,33.3,30.0,28.7,26.0$ (3 C), 18.3, 17.2, -4.2, -4.6.

HRMS (ESI+): $m / z[\mathrm{M}+\mathrm{Na}]^{+}$calcd for $\mathrm{C}_{17} \mathrm{H}_{30} \mathrm{O}_{2} \mathrm{SiNa}$ : 317.1907 ; found: 317.1909.

\section{(Z)-7-[(tert-Butyldimethylsilyl)oxy]-5-methyldec-5-en-9-yn-2-ol [(Z)-S3d]}

Prepared on $300 \mathrm{mg}$ scale from $(Z)-\mathbf{7 b}$ according to method $A$ and using a commercial solution of $\mathrm{MeMgBr}$ in $\mathrm{Et}_{2} \mathrm{O}(3 \mathrm{M})$. The product was purified by silica gel column chromatography eluting with cyclohexane/EtOAc (95:5 to 9:1) and obtained as a colorless oil (220 mg, $69 \%$, ca. $1.35: 1 \mathrm{dr} ; 81 \%$ based on recovered starting material) (plus $45 \mathrm{mg}$ recovered aldehyde, $15 \%)$.

${ }^{1} \mathrm{H}$ NMR (500 MHz, $\left.\mathrm{CDCl}_{3}\right): \delta=5.20-5.14(\mathrm{~m}, 1 \mathrm{H}$ major $+1 \mathrm{H}$ minor $)$, 4.59-4.52 (m, $1 \mathrm{H}$ major $+1 \mathrm{H}$ minor $), 3.83-3.75$ ( $\mathrm{m}, 1 \mathrm{H}$ major $+1 \mathrm{H}$ minor), 2.43-2.36 (m, $1 \mathrm{H}$ major + $1 \mathrm{H}$ minor), 2.32-2.19 ( $\mathrm{m}, 2 \mathrm{H}$ major $+2 \mathrm{H}$ minor $), 2.13-2.02(\mathrm{~m}, 1 \mathrm{H}$ major $+1 \mathrm{H}$ minor $), 1.94$ and 1.93 (two t, $J=2.7 \mathrm{~Hz}, 1 \mathrm{H} \mathrm{major}+1 \mathrm{H} \mathrm{minor}), 1.72(\mathrm{~d}, J=1.4 \mathrm{~Hz}, 3 \mathrm{H} \mathrm{mi}-$ nor), 1.71 (d, $J=1.4 \mathrm{~Hz}, 3 \mathrm{H}$ major), 1.59-1.51 (m, $2 \mathrm{H}$ major $+2 \mathrm{H}$ minor), 1.21 and 1.21 (two $\mathrm{d}, J=6.2 \mathrm{~Hz}, 3 \mathrm{H}$ major $+3 \mathrm{H}$ minor), 0.87 (s, 9 H minor), 0.87 (s, $9 \mathrm{H}$ major), 0.06 (s, $3 \mathrm{H}$ major + $3 \mathrm{H}$ minor), 0.04 (s, $3 \mathrm{H}$ minor), 0.03 (s, $3 \mathrm{H}$ major).

${ }^{13} \mathrm{C}$ NMR $\left(126 \mathrm{MHz}, \mathrm{CDCl}_{3}\right): \delta=136.7,136.6,128.8,128.7,82.1,82.0$, 69.7, 69.6, 68.3, 68.1, 68.0, 67.8, 37.7, 37.4, 29.0, 29.0, 28.9, 28.7, 26.0 (3 C major + 3 C minor), 23.9, 23.8, 23.3, 23.3, 18.3 (1 C major + 1 C minor), -4.1 (1 C major + $1 \mathrm{C}$ minor), $-4.5,-4.5$.

HRMS (ESI+): $m / z[\mathrm{M}+\mathrm{Na}]^{+}$calcd for $\mathrm{C}_{17} \mathrm{H}_{32} \mathrm{O}_{2} \mathrm{SiNa}$ : 319.2064 ; found: 319.2074 .

\section{(Z)-7-[(tert-Butyldimethylsilyl)oxy]-5-methyldec-5-en-9-yn-2-one [(Z)-7d]}

Prepared on $205 \mathrm{mg}$ scale from (Z)-S3d according to method A. The product was purified by silica gel column chromatography eluting with cyclohexane/EtOAc (95:5 to 9:1) to afford a colorless oil (193 mg, $93 \%$ ); $65 \%$ yield over 2 steps ( $75 \%$ based on recovered starting material).

${ }^{1} \mathrm{H}$ NMR $\left(500 \mathrm{MHz}, \mathrm{CDCl}_{3}\right): \delta=5.20-5.15(\mathrm{~m}, 1 \mathrm{H}), 4.52(\mathrm{dt}, J=8.8,6.4$ $\mathrm{Hz}, 1 \mathrm{H}), 2.53$ (app t, $J=7.9 \mathrm{~Hz}, 2 \mathrm{H}), 2.44-2.34(\mathrm{~m}, 2 \mathrm{H}), 2.30-2.23(\mathrm{~m}$, $2 \mathrm{H}), 2.15(\mathrm{~s}, 3 \mathrm{H}), 1.92(\mathrm{t}, J=2.6 \mathrm{~Hz}, 1 \mathrm{H}), 1.68(\mathrm{~d}, J=1.4 \mathrm{~Hz}, 3 \mathrm{H}), 0.86$ (s, $9 \mathrm{H}), 0.06(\mathrm{~s}, 3 \mathrm{H}), 0.02(\mathrm{~s}, 3 \mathrm{H})$.

${ }^{13} \mathrm{C}$ NMR $\left(126 \mathrm{MHz}, \mathrm{CDCl}_{3}\right): \delta=208.0,135.2,129.5,81.9,69.6,68.0$, 42.2, 30.1, 28.9, 26.4, 25.9 (3 C), 23.1, 18.3, -4.2, -4.5.

HRMS (ESI+): $m / z[\mathrm{M}+\mathrm{Na}]^{+}$calcd for $\mathrm{C}_{17} \mathrm{H}_{30} \mathrm{O}_{2} \mathrm{SiNa}$ : 317.1907 ; found: 317.1906.

\section{(E)-9-Cyclopropyl-9-hydroxy-6-methylnon-5-en-1-yn-4-yl Benzo- ate $[(E)-S 3 e]$}

Prepared on $268 \mathrm{mg}$ scale from (E)-7a according to method A and using a freshly prepared solution of $c-\mathrm{C}_{3} \mathrm{H}_{5} \mathrm{MgBr}$ in $\mathrm{Et}_{2} \mathrm{O}(\sim 0.4 \mathrm{M})$. The product was purified by silica gel column chromatography eluting with cyclohexane/EtOAc (8:2) and obtained as a colorless oil (116 mg, $37 \%$, ca. $1: 1 d r$ ). Note: in the proton assignments below ' $1 \mathrm{H}+1 \mathrm{H}$ ' refers to a signal accounting for one proton of each diastereomer; likewise, ' $1 \mathrm{C}+1 \mathrm{C}$ ' refers to a signal accounting for one carbon of each diastereomer.
${ }^{1} \mathrm{H}$ NMR $\left(400 \mathrm{MHz}, \mathrm{CDCl}_{3}\right): \delta=8.07-8.02(\mathrm{~m}, 2 \mathrm{H}+2 \mathrm{H}), 7.55$ (app t, $J=7.2 \mathrm{~Hz}, 1 \mathrm{H}+1 \mathrm{H}$ ), 7.43 (app t, $J=7.8 \mathrm{~Hz}, 2 \mathrm{H}+2 \mathrm{H}$ ), 5.86 (app dtd, $J=8.9,6.1,1.5 \mathrm{~Hz}, 1 \mathrm{H}+1 \mathrm{H}), 5.39($ app d, $J=9.2 \mathrm{~Hz}, 1 \mathrm{H}+1 \mathrm{H}), 2.85$ (app quin, $J=6.4 \mathrm{~Hz}, 1 \mathrm{H}+1 \mathrm{H}), 2.70-2.56(\mathrm{~m}, 2 \mathrm{H}+2 \mathrm{H}$ ), 2.29-2.10 (m, $2 \mathrm{H}+2 \mathrm{H}), 2.00-1.96(\mathrm{~m}, 1 \mathrm{H}+1 \mathrm{H}), 1.84(\mathrm{~s}, 3 \mathrm{H}+3 \mathrm{H}), 1.79-1.70$ (m, $2 \mathrm{H}+2 \mathrm{H}), 0.96-0.85(\mathrm{~m}, 1 \mathrm{H}+1 \mathrm{H}), 0.57-0.45(\mathrm{~m}, 2 \mathrm{H}+2 \mathrm{H})$, $0.30-0.16(\mathrm{~m}, 2 \mathrm{H}+2 \mathrm{H})$.

${ }^{13} \mathrm{C}$ NMR $\left(101 \mathrm{MHz}, \mathrm{CDCl}_{3}\right): \delta=165.9,165.9,142.5,142.4,133.0(1 \mathrm{C}+$ $1 \mathrm{C}), 130.6,130.6,129.8(2 \mathrm{C}+2 \mathrm{C}), 128.5(2 \mathrm{C}+2 \mathrm{C}), 122.1,122.0$, 79.8, 79.8, 76.5, 76.4, 70.4, 70.3, 69.7 (1 C + 1 C), 35.8, 35.8, 35.2, 35.1, $25.3,25.3,18.1,18.1,17.3,17.3,2.9,2.9,2.7,2.7$.

HRMS (ESI+): $m / z[\mathrm{M}+\mathrm{Na}]^{+}$calcd for $\mathrm{C}_{20} \mathrm{H}_{24} \mathrm{O}_{3} \mathrm{Na}$ : 335.1618; found: 335.1614.

\section{(E)-9-Cyclopropyl-6-methyl-9-oxonon-5-en-1-yn-4-yl Benzoate [(E)-7e]}

Prepared on $115 \mathrm{mg}$ scale from (E)-S3e according to method A. The product was purified by silica gel column chromatography eluting with cyclohexane/EtOAc (8:2) to afford a colorless oil (84.3 mg, 73\%); $27 \%$ yield over 2 steps.

${ }^{1} \mathrm{H} \mathrm{NMR}\left(500 \mathrm{MHz}, \mathrm{CDCl}_{3}\right): \delta=8.07-8.02(\mathrm{~m}, 2 \mathrm{H}), 7.58-7.53(\mathrm{~m}, 1 \mathrm{H})$, 7.46-7.41 (m, $2 \mathrm{H}), 5.85(\mathrm{dt}, J=9.1,6.1 \mathrm{~Hz}, 1 \mathrm{H}), 5.39-5.35(\mathrm{~m}, 1 \mathrm{H})$, 2.72-2.67 (m, $2 \mathrm{H}), 2.67-2.57(\mathrm{~m}, 2 \mathrm{H}), 2.36(\mathrm{td}, J=7.7,1.3 \mathrm{~Hz}, 2 \mathrm{H})$, $1.98(\mathrm{t}, J=2.6 \mathrm{~Hz}, 1 \mathrm{H}), 1.92(\mathrm{tt}, J=7.8,4.5 \mathrm{~Hz}, 1 \mathrm{H}), 1.84(\mathrm{~d}, J=1.4 \mathrm{~Hz}$, $3 \mathrm{H}), 1.04-0.96(\mathrm{~m}, 2 \mathrm{H}), 0.90-0.80(\mathrm{~m}, 2 \mathrm{H})$.

${ }^{13} \mathrm{C}$ NMR (126 MHz, $\left.\mathrm{CDCl}_{3}\right): \delta=210.2,165.9,141.2,133.1,130.5$, 129.8 (2 C), 128.5 (2 C), 122.3, 79.7, 70.4, 69.5, 41.8, 33.6, 25.2, 20.6, $17.4,10.9,10.9$.

HRMS (ESI+): $m / z[\mathrm{M}+\mathrm{Na}]^{+}$calcd for $\mathrm{C}_{20} \mathrm{H}_{22} \mathrm{O}_{3} \mathrm{Na}$ : 333.1461; found: 333.1450.

\section{(Z)-9-Cyclopropyl-9-hydroxy-6-methylnon-5-en-1-yn-4-yl Benzo- ate $[(Z)-S 3 e]$}

Prepared on $300 \mathrm{mg}$ scale from $(Z)-7 \mathbf{a}$ according to method $A$ and using a freshly prepared solution of $c-\mathrm{C}_{3} \mathrm{H}_{5} \mathrm{MgBr}$ in $\mathrm{Et}_{2} \mathrm{O}(\sim 0.4 \mathrm{M})$. The product was purified by silica gel column chromatography eluting with cyclohexane/EtOAc (9:1 to 3:1) and obtained as a colorless oil ( $230 \mathrm{mg}, 66 \%$, ca. $4: 3 \mathrm{dr} ; 80 \%$ based on recovered starting material) (plus $51 \mathrm{mg}$ recovered starting material, 17\%).

${ }^{1} \mathrm{H} \mathrm{NMR}\left(500 \mathrm{MHz}, \mathrm{CDCl}_{3}\right): \delta=8.07-8.02(\mathrm{~m}, 2 \mathrm{H}$ major $+2 \mathrm{H}$ minor $)$, 7.58-7.52 (m, $1 \mathrm{H}$ major + $1 \mathrm{H}$ minor), 7.46-7.40 (m, $2 \mathrm{H}$ major $+2 \mathrm{H}$ minor), 5.96-5.89 ( $\mathrm{m}, 1 \mathrm{H}$ major + $1 \mathrm{H}$ minor), 5.39-5.33 ( $\mathrm{m}, 1 \mathrm{H}$ major + $1 \mathrm{H}$ minor), 2.92-2.82 ( $\mathrm{m}, 1 \mathrm{H}$ major + $1 \mathrm{H} \mathrm{minor}), 2.69-2.57(\mathrm{~m}, 2 \mathrm{H}$ major + $2 \mathrm{H}$ minor), 2.53 (dt, $J=13.5,8.3 \mathrm{~Hz}, 1 \mathrm{H}$ major $), 2.50-2.33(\mathrm{~m}$, $2 \mathrm{H}$ minor), 2.22 (ddd, $J=13.5,8.5,5.3 \mathrm{~Hz}, 1 \mathrm{H}$ major), 2.00 and 1.99 (two t, $J=2.7 \mathrm{~Hz}, 1 \mathrm{H}$ major $+1 \mathrm{H}$ minor), 1.87-1.62 ( $\mathrm{m}, 3+2 \mathrm{H}$ major $+3+2 \mathrm{H}$ minor), 0.95-0.86 ( $\mathrm{m}, 1 \mathrm{H}$ major $+1 \mathrm{H}$ minor $), 0.55-0.43$ ( $\mathrm{m}$, $3 \mathrm{H}$ major + $1 \mathrm{H}$ minor), 0.31-0.23 (m, $1 \mathrm{H} \mathrm{major} \mathrm{+} 1 \mathrm{H} \mathrm{minor),} \mathrm{0.23-}$ 0.17 ( $\mathrm{m}, 1 \mathrm{H}$ minor), 0.17-0.12 ( $\mathrm{m}, 1 \mathrm{H}$ minor).

${ }^{13} \mathrm{C}$ NMR (126 MHz, $\left.\mathrm{CDCl}_{3}\right): \delta=166.1,165.9,143.2,142.3,133.1$, $133.0,130.6,130.5,129.9$ (2 C one diastereomer), 129.8 (2 C one diastereomer), 128.5 (2 C one diastereomer), 128.4 (2 C one diastereomer), 123.1, 122.6, 80.0, 79.8, 76.3, 75.5, 70.5, 70.4, 69.7, 69.3, 35.6, 35.0, 29.0, 28.7, 25.6, 25.4, 23.5, 23.3, 18.1, 17.9, 2.8, 2.7, 2.7, 2.6.

HRMS (ESI+): $m / z[\mathrm{M}+\mathrm{Na}]^{+}$calcd for $\mathrm{C}_{20} \mathrm{H}_{24} \mathrm{O}_{3} \mathrm{Na}$ : 335.1618; found: 335.1620 . 


\section{(Z)-9-Cyclopropyl-6-methyl-9-oxonon-5-en-1-yn-4-yl Benzoate [(Z)-7e]}

Prepared on $215 \mathrm{mg}$ scale from $(Z)-\mathbf{S 3 e}$ according to method A. The product was purified by silica gel column chromatography eluting with cyclohexane/EtOAc (9:1) to afford a colorless oil (184 mg, 86\%); $57 \%$ yield over 2 steps ( $69 \%$ based on recovered starting material).

${ }^{1} \mathrm{H}$ NMR $\left(500 \mathrm{MHz}, \mathrm{CDCl}_{3}\right): \delta=8.07-8.02(\mathrm{~m}, 2 \mathrm{H}), 7.57-7.52(\mathrm{~m}, 1 \mathrm{H})$, 7.46-7.40 (m, $2 \mathrm{H}), 5.86(\mathrm{dt}, J=9.3,6.0 \mathrm{~Hz}, 1 \mathrm{H}), 5.40-5.35(\mathrm{~m}, 1 \mathrm{H})$, 2.75 (ddd, $J=16.7,9.7,5.9 \mathrm{~Hz}, 1 \mathrm{H}$ ), 2.71-2.59 (m, $3 \mathrm{H}$ ), 2.56 (dddd, $J=$ 13.7, 9.7, 5.9, $0.7 \mathrm{~Hz}, 1 \mathrm{H}$ ), 2.49 (dddd, $J=13.8,9.7,6.0,0.8 \mathrm{~Hz}, 1 \mathrm{H}$ ), $2.00(\mathrm{t}, J=2.7 \mathrm{~Hz}, 1 \mathrm{H}), 1.93(\mathrm{tt}, J=7.8,4.6 \mathrm{~Hz}, 1 \mathrm{H}), 1.76(\mathrm{~d}, J=1.4 \mathrm{~Hz}$, $3 \mathrm{H}), 1.04-1.00$ (m, $2 \mathrm{H}), 0.88-0.83$ (m, $2 \mathrm{H})$.

${ }^{13} \mathrm{C}$ NMR (126 MHz, $\mathrm{CDCl}_{3}$ ): $\delta=210.1,165.8,141.3,133.0,130.5$, 129.8 (2 C), 128.4 (2 C), 123.4, 79.9, 70.5, 69.3, 41.8, 27.0, 25.4, 23.4, $20.5,10.9(2 \mathrm{C})$.

HRMS (ESI+): $m / z[\mathrm{M}+\mathrm{Na}]^{+}$calcd for $\mathrm{C}_{20} \mathrm{H}_{22} \mathrm{O}_{3} \mathrm{Na}$ : 333.1461; found: 333.1458 .

\section{(Z)-9-Cyclopentyl-6-methyl-9-oxonon-5-en-1-yn-4-yl Benzoate [(Z)-7f]}

Prepared on $300 \mathrm{mg}$ scale from (Z)-7a according to method B and using a freshly prepared solution of $c-\mathrm{C}_{5} \mathrm{H}_{9} \mathrm{MgBr}$ in $\mathrm{Et}_{2} \mathrm{O}(\sim 1.2 \mathrm{M})$. The product was purified by silica gel column chromatography eluting with cyclohexane/EtOAc (95:5 to 4:1) and isolated as a colorless oil (109 mg, 29\% over 2 steps; $75 \%$ based on recovered starting material) (plus $184 \mathrm{mg}$ of recovered aldehyde, 61\%).

${ }^{1} \mathrm{H}$ NMR (500 MHz, $\mathrm{CDCl}_{3}$ ): $\delta=8.06-8.02(\mathrm{~m}, 2 \mathrm{H}$ ), $7.54(\mathrm{ddt}, J=8.8$, 7.0, $1.4 \mathrm{~Hz}, 1 \mathrm{H}), 7.45-7.40(\mathrm{~m}, 2 \mathrm{H}), 5.85(\mathrm{dt}, J=9.3,6.0 \mathrm{~Hz}, 1 \mathrm{H}), 5.37$ (dd, $J=9.2,1.5 \mathrm{~Hz}, 1 \mathrm{H}), 2.89-2.81(\mathrm{~m}, 1 \mathrm{H}), 2.68-2.41(\mathrm{~m}, 6 \mathrm{H}), 2.00$ (t, $J=2.7 \mathrm{~Hz}, 1 \mathrm{H}), 1.84-1.49(\mathrm{~m}, 11 \mathrm{H})$.

${ }^{13} \mathrm{C}$ NMR $\left(126 \mathrm{MHz}, \mathrm{CDCl}_{3}\right): \delta=212.4,165.7,141.5,133.0,130.6$, 129.8 (2 C), 128.4 (2 C), 123.3, 79.9, 70.5, 69.3, 51.5, 40.1, 29.0, 29.0, 26.9, 26.1, 26.1, 25.3, 23.4.

HRMS (ESI+): $m / z$ [M + Na] calcd for $\mathrm{C}_{22} \mathrm{H}_{26} \mathrm{O}_{3} \mathrm{Na}$ : 361.1774; found: 361.1767.

(E)-6-Methyl-9-oxo-9-phenylnon-5-en-1-yn-4-yl Benzoate [(E)-7g] Prepared on $300 \mathrm{mg}$ scale from $(E)-7 \mathbf{a}$ according to method $\mathrm{B}$ and using a commercial solution of $\mathrm{PhMgBr}$ in $\mathrm{Et}_{2} \mathrm{O}(3 \mathrm{M})$. The product was purified by silica gel column chromatography eluting with cyclohexane/EtOAc (4:1 to 3:1) and isolated as a colorless oil (233 $\mathrm{mg}, 61 \%$ over 2 steps).

${ }^{1} \mathrm{H}$ NMR (300 MHz, $\left.\mathrm{CDCl}_{3}\right): \delta=8.10-8.03(\mathrm{~m}, 2 \mathrm{H}), 8.00-7.93(\mathrm{~m}, 2 \mathrm{H})$, 7.61-7.53 (m, $2 \mathrm{H}), 7.51-7.41(\mathrm{~m}, 4 \mathrm{H}), 5.89(\mathrm{dt}, J=9.0,6.1 \mathrm{~Hz}, 1 \mathrm{H})$, 5.43 (app dq, $J=9.1,1.3 \mathrm{~Hz}, 1 \mathrm{H}), 3.17-3.08(\mathrm{~m}, 2 \mathrm{H}), 2.64(\mathrm{dt}, J=5.8$, $2.5 \mathrm{~Hz}, 2 \mathrm{H}), 2.56-2.47(\mathrm{~m}, 2 \mathrm{H}), 1.98(\mathrm{t}, J=2.4 \mathrm{~Hz}, 1 \mathrm{H}), 1.91(\mathrm{~s}, 3 \mathrm{H})$.

${ }^{13} \mathrm{C}$ NMR $\left(126 \mathrm{MHz}, \mathrm{CDCl}_{3}\right): \delta=199.6,165.9,141.3,137.1,133.2$, 133.1, 130.5, 129.8 (2 C), 128.7 (2 C), 128.5 (2 C), 128.2 (2 C), 122.5, 79.7, 70.4, 69.5, 37.0, 33.9, 25.2, 17.5.

HRMS (ESI+): $m / z[\mathrm{M}+\mathrm{Na}]^{+}$calcd for $\mathrm{C}_{23} \mathrm{H}_{22} \mathrm{O}_{3} \mathrm{Na}$ : 369.1461; found: 369.1449 .

(Z)-6-Methyl-9-oxo-9-phenylnon-5-en-1-yn-4-yl Benzoate [(Z)-7g] Prepared on $300 \mathrm{mg}$ scale from $(Z)-7 \mathbf{a}$ according to method $\mathrm{B}$ and using a commercial solution of $\mathrm{PhMgBr}$ in $\mathrm{Et}_{2} \mathrm{O}(3 \mathrm{M})$. The product was purified by silica gel column chromatography eluting with cyclohexane/EtOAc (95:5 to 9:1) and isolated as a colorless solid (279 mg, 73\% over 2 steps).
Mp $40-43^{\circ} \mathrm{C}$.

${ }^{1} \mathrm{H}$ NMR $\left(500 \mathrm{MHz}, \mathrm{CDCl}_{3}\right): \delta=8.07-8.02(\mathrm{~m}, 2 \mathrm{H}), 7.99-7.93(\mathrm{~m}, 2 \mathrm{H})$, 7.58-7.51 (m, $2 \mathrm{H}$ ), 7.48-7.39 (m, $4 \mathrm{H}), 5.88$ (dt, $J=9.3,6.0 \mathrm{~Hz}, 1 \mathrm{H}$ ), 5.41 (app d, $J=9.9 \mathrm{~Hz}, 1 \mathrm{H}$ ), 3.21 (ddd, $J=17.0,9.6,5.7 \mathrm{~Hz}, 1 \mathrm{H}$ ), 3.09 (ddd, $J=17.0,9.7,6.1 \mathrm{~Hz}, 1 \mathrm{H}$ ), 2.75-2.60 (m, $4 \mathrm{H}), 2.00$ (t, $J=2.6 \mathrm{~Hz}, 1$ $\mathrm{H}), 1.82(\mathrm{~d}, J=1.4 \mathrm{~Hz}, 3 \mathrm{H})$.

${ }^{13} \mathrm{C}$ NMR (126 MHz, $\left.\mathrm{CDCl}_{3}\right): \delta=199.6,165.7,141.3,137.0,133.1$, 133.0, 130.5, 129.8 (2 C), 128.7 (2 C), 128.4 (2 C), 128.2 (2 C), 123.6, 79.9, 70.5, 69.4, 37.1, 27.3, 25.4, 23.5.

HRMS (ESI+): $m / z[\mathrm{M}+\mathrm{Na}]^{+}$calcd for $\mathrm{C}_{23} \mathrm{H}_{22} \mathrm{O}_{3} \mathrm{Na}$ : 369.1461; found: 369.1469 .

(E)-6-[(tert-Butyldimethylsilyl)oxy]-4-methyl-1-phenylnon-4-en8-yn-1-one [(E)-7h]

Prepared on $309 \mathrm{mg}$ scale from $(E)-\mathbf{7 b}$ according to method B and using a commercial solution of $\mathrm{PhMgBr}$ in $\mathrm{Et}_{2} \mathrm{O}(3 \mathrm{M})$. The product was purified by silica gel column chromatography eluting with cyclohexane/EtOAc (4:1 to 3:1) and isolated as a colorless oil (201 mg, 51\% over 2 steps).

${ }^{1} \mathrm{H} \mathrm{NMR}\left(500 \mathrm{MHz}, \mathrm{CDCl}_{3}\right): \delta=7.98-7.93(\mathrm{~m}, 2 \mathrm{H}), 7.59-7.54(\mathrm{~m}, 1 \mathrm{H})$, 7.49-7.44 (m, $2 \mathrm{H}$ ), 5.21 (app dq, $J=8.6,1.3 \mathrm{~Hz}, 1 \mathrm{H}$ ), 4.54 (dt, $J=8.6$, $6.5 \mathrm{~Hz}, 1 \mathrm{H}), 3.11-3.06(\mathrm{~m}, 2 \mathrm{H}), 2.46-2.41(\mathrm{~m}, 2 \mathrm{H}), 2.39$ (ddd, $J=$ 16.5, 6.5, $2.7 \mathrm{~Hz}, 1 \mathrm{H}$ ), 2.27 (ddd, $J=16.5,6.4,2.7 \mathrm{~Hz}, 1 \mathrm{H}$ ), 1.91 (t, $J=$ $2.6 \mathrm{~Hz}, 1 \mathrm{H}), 1.74(\mathrm{~d}, J=1.3 \mathrm{~Hz}, 3 \mathrm{H}), 0.87(\mathrm{~s}, 9 \mathrm{H}), 0.07$ (s, $3 \mathrm{H}), 0.03$ (s, $3 \mathrm{H})$.

${ }^{13} \mathrm{C}$ NMR $\left(126 \mathrm{MHz}, \mathrm{CDCl}_{3}\right): \delta=199.7,137.1,135.5,133.1,128.7(2 \mathrm{C})$, $128.4,128.2$ (2 C), 81.8, 69.5, 68.5, 37.1, 33.8, 28.7, 26.0 (3 C), 18.4, $17.3,-4.2,-4.6$.

HRMS (ESI+): $m / z[\mathrm{M}+\mathrm{Na}]^{+}$calcd for $\mathrm{C}_{22} \mathrm{H}_{32} \mathrm{O}_{2} \mathrm{SiNa}$ : 379.2064; found: 369.2057.

(Z)-7-[(tert-Butyldimethylsilyl)oxy]-4-methyl-1-phenylnon-4-en8-yn-1-one $[(Z)-7 h]$

Prepared on $300 \mathrm{mg}$ scale from $(Z)-\mathbf{7 b}$ according to method $\mathrm{B}$ and using a commercial solution of $\mathrm{PhMgBr}$ in $\mathrm{Et}_{2} \mathrm{O}(3 \mathrm{M})$. The product was purified by silica gel column chromatography eluting with cyclohexane/EtOAc (95:5 to 9:1) and isolated as a pale yellow oil (232 mg, 61\% over 2 steps) (plus $75 \mathrm{mg}$ of recovered aldehyde, 25\%; $81 \%$ based on recovered starting material).

${ }^{1} \mathrm{H} \mathrm{NMR}\left(500 \mathrm{MHz}, \mathrm{CDCl}_{3}\right): \delta=7.99-7.93(\mathrm{~m}, 2 \mathrm{H}), 7.60-7.54(\mathrm{~m}, 1 \mathrm{H})$, 7.50-7.44 (m, $2 \mathrm{H}), 5.25-5.20(\mathrm{~m}, 1 \mathrm{H}), 4.57(\mathrm{dt}, J=8.8,6.4 \mathrm{~Hz}, 1 \mathrm{H})$, 3.15-3.02 (m, $2 \mathrm{H}$ ), 2.65-2.57 ( $\mathrm{m}, 1 \mathrm{H}$ ), 2.46-2.37 ( $\mathrm{m}, 2 \mathrm{H}$ ), 2.30 (ddd, $J=16.5,6.7,2.7 \mathrm{~Hz}, 1 \mathrm{H}), 1.91(\mathrm{t}, J=2.6 \mathrm{~Hz}, 1 \mathrm{H}), 1.77(\mathrm{~d}, J=1.4 \mathrm{~Hz}, 3$ $\mathrm{H}), 0.87(\mathrm{~s}, 9 \mathrm{H}), 0.07(\mathrm{~s}, 3 \mathrm{H}), 0.04(\mathrm{~s}, 3 \mathrm{H})$.

${ }^{13} \mathrm{C}$ NMR $\left(126 \mathrm{MHz}, \mathrm{CDCl}_{3}\right): \delta=199.6,137.0,135.5,133.2,129.6$, 128.8 (2 C), 128.1 (2 C), 82.0, 69.7, 68.1, 37.3, 28.9, 26.9, 26.0 (3 C), $23.3,18.3,-4.1,-4.5$.

HRMS (ESI+): $m / z$ [M + Na] ${ }^{+}$calcd for $\mathrm{C}_{22} \mathrm{H}_{32} \mathrm{O}_{2} \mathrm{SiNa}$ : 379.2064; found: 379.2069.

(E)-6-Methyl-9-oxo-9-[4-(trifluoromethyl)phenyl]non-5-en-1-yn4-yl Benzoate $[(E)-7 i]$

Prepared on $300 \mathrm{mg}$ scale from (E)-7a according to method $\mathrm{B}$ and using a freshly prepared solution of $4-\mathrm{F}_{3} \mathrm{C}-\mathrm{C}_{6} \mathrm{H}_{4} \mathrm{MgBr}$ in $\mathrm{Et}_{2} \mathrm{O}(\sim 0.8 \mathrm{M})$. The product was purified by silica gel column chromatography eluting with pentane/ $\mathrm{Et}_{2} \mathrm{O}$ (95:5 to 9:1) and isolated as a pale yellow oil (324 mg, 71\% over 2 steps). 
${ }^{1} \mathrm{H}$ NMR $\left(400 \mathrm{MHz}, \mathrm{CDCl}_{3}\right): \delta=8.06-8.02(\mathrm{~m}, 4 \mathrm{H}), 7.73-7.69(\mathrm{~m}, 2 \mathrm{H})$, 7.59-7.53 (m, $1 \mathrm{H}), 7.47-7.41(\mathrm{~m}, 2 \mathrm{H}), 5.86(\mathrm{dt}, J=9.0,6.1 \mathrm{~Hz}, 1 \mathrm{H})$, 5.40 (app dq, $J=9.1,1.3 \mathrm{~Hz}, 1 \mathrm{H}), 3.16-3.10(\mathrm{~m}, 2 \mathrm{H}), 2.69-2.57(\mathrm{~m}, 2$ H), 2.54-2.48 (m, $2 \mathrm{H}), 1.97$ (t, J = 2.6 Hz, $1 \mathrm{H}), 1.89$ (d, $J=1.3 \mathrm{~Hz}, 3 \mathrm{H})$. ${ }^{13} \mathrm{C} \mathrm{NMR}\left(126 \mathrm{MHz}, \mathrm{CDCl}_{3}\right): \delta=198.6,165.8,140.8,139.7$ (app d, $J_{\mathrm{C}-\mathrm{F}}=$ $1.0 \mathrm{~Hz}), 134.5\left(\mathrm{q}, J_{\mathrm{C}-\mathrm{F}}=32.5 \mathrm{~Hz}\right), 133.1,130.4,129.8(2 \mathrm{C}), 128.5(4 \mathrm{C})$, $125.8\left(\mathrm{q}, J_{\mathrm{C}-\mathrm{F}}=3.7 \mathrm{~Hz}, 2 \mathrm{C}\right), 123.7\left(\mathrm{q}, J_{\mathrm{C}-\mathrm{F}}=273.4 \mathrm{~Hz}\right), 122.8,79.6,70.5$, $69.5,37.3,33.6,25.2,17.5$.

${ }^{19} \mathrm{~F}$ NMR (376 MHz, $\left.\mathrm{CDCl}_{3}\right): \delta=-62.83$.

HRMS (ESI+): $m / z$ [M + Na] $]^{+}$calcd for $\mathrm{C}_{24} \mathrm{H}_{21} \mathrm{~F}_{3} \mathrm{O}_{3} \mathrm{Na}$ : 437.1335; found: 437.1333.

(Z)-6-Methyl-9-oxo-9-[4-(trifluoromethyl)phenyl]non-5-en-1-yn4-yl Benzoate [(Z)-7i]

Prepared on $300 \mathrm{mg}$ scale from $(Z)-7 \mathbf{a}$ according to method $\mathrm{B}$ and using a freshly prepared solution of $4-\mathrm{F}_{3} \mathrm{C}-\mathrm{C}_{6} \mathrm{H}_{4} \mathrm{MgBr}$ in $\mathrm{Et}_{2} \mathrm{O}(\sim 0.8 \mathrm{M})$. The product was purified by silica gel column chromatography eluting with pentane/ $\mathrm{Et}_{2} \mathrm{O}$ (95:5 to 9:1) and isolated as a pale yellow solid (204 mg, 44\% over 2 steps).

Mp $42-44{ }^{\circ} \mathrm{C}$ (pentane).

${ }^{1} \mathrm{H}$ NMR $\left(400 \mathrm{MHz}, \mathrm{CDCl}_{3}\right): \delta=8.10-8.00(\mathrm{~m}, 4 \mathrm{H}), 7.71$ (app d, $J=8.1$ $\mathrm{Hz}, 2 \mathrm{H}), 7.58-7.51(\mathrm{~m}, 1 \mathrm{H}), 7.46-7.38(\mathrm{~m}, 2 \mathrm{H}), 5.87$ (dt, $J=9.4,6.1$ $\mathrm{Hz}, 1 \mathrm{H}$ ), 5.42 (app dd, $J=9.4,1.5 \mathrm{~Hz}, 1 \mathrm{H}$ ), 3.26 (ddd, $J=17.2,9.3,6.0$ $\mathrm{Hz}, 1 \mathrm{H}$ ), 3.09 (ddd, $J=17.2,9.1,6.7 \mathrm{~Hz}, 1 \mathrm{H}), 2.75-2.59$ (m, $4 \mathrm{H}$ ), 2.01 (t, $J=2.6 \mathrm{~Hz}, 1 \mathrm{H}), 1.82(\mathrm{~d}, J=1.4 \mathrm{~Hz}, 3 \mathrm{H})$.

${ }^{13} \mathrm{C} \mathrm{NMR}\left(101 \mathrm{MHz}, \mathrm{CDCl}_{3}\right): \delta=198.6,165.8,141.0,139.6$ (app d, $J_{\mathrm{C}-\mathrm{F}}=$ $1.1 \mathrm{~Hz}), 134.4\left(\mathrm{q}, J_{\mathrm{C}-\mathrm{F}}=32.6 \mathrm{~Hz}\right), 133.1,130.4,129.8(2 \mathrm{C}), 128.6(2 \mathrm{C})$, $128.5(2 \mathrm{C}), 125.8\left(\mathrm{q}, J_{\mathrm{C}-\mathrm{F}}=3.7 \mathrm{~Hz}, 2 \mathrm{C}\right), 123.9,123.8\left(\mathrm{q}, J_{\mathrm{C}-\mathrm{F}}=272.7 \mathrm{~Hz}\right)$, 79.8, 70.6, 69.4, 37.4, 27.1, 25.3, 23.5.

${ }^{19} \mathrm{~F}$ NMR $\left(376 \mathrm{MHz}, \mathrm{CDCl}_{3}\right): \delta=-63.19$.

HRMS (ESI+): $m / z[\mathrm{M}+\mathrm{Na}]^{+}$calcd for $\mathrm{C}_{24} \mathrm{H}_{21} \mathrm{O}_{3} \mathrm{~F}_{3} \mathrm{Na}$ : 437.1335; found: 437.1337.

\section{(Z)-6-Methyl-9-(naphthalene-2-yl)-9-oxonon-5-en-1-yn-4-yl Ben-} zoate $[(Z)-7 \mathbf{j}]$

Prepared on $300 \mathrm{mg}$ scale from $(Z)-\mathbf{7 b}$ according to method $B$ and using a freshly prepared solution of 2-naphthyl-MgBr in $\mathrm{Et}_{2} \mathrm{O}(\sim 0.4 \mathrm{M})$. The product was purified by silica gel column chromatography eluting with cyclohexane/EtOAc (9:1 to 3:1) and isolated as a pale yellow solid ( $269 \mathrm{mg}, 61 \%$ over 2 steps).

Mp $74-77^{\circ} \mathrm{C}$.

${ }^{1} \mathrm{H} \mathrm{NMR}\left(500 \mathrm{MHz}, \mathrm{CDCl}_{3}\right): \delta=8.52(\mathrm{~d}, J=1.7 \mathrm{~Hz}, 1 \mathrm{H}), 8.08-8.02(\mathrm{~m}, 3$ $\mathrm{H}), 7.96(\mathrm{~d}, J=8.0 \mathrm{~Hz}, 1 \mathrm{H}), 7.91-7.85(\mathrm{~m}, 2 \mathrm{H}), 7.60$ (ddd, $J=8.2,6.9$, $1.4 \mathrm{~Hz}, 1 \mathrm{H}), 7.57-7.51(\mathrm{~m}, 2 \mathrm{H}), 7.44-7.39(\mathrm{~m}, 2 \mathrm{H}), 5.93$ (dt, $J=9.3$, $6.1 \mathrm{~Hz}, 1 \mathrm{H}), 5.44(\mathrm{dd}, J=9.4,1.6 \mathrm{~Hz}, 1 \mathrm{H}), 3.37$ (ddd, $J=16.7,8.7,6.7$ $\mathrm{Hz}, 1 \mathrm{H}$ ), 3.21 (ddd, $J=16.7,9.0,6.9 \mathrm{~Hz}, 1 \mathrm{H}$ ), 2.74 (app ddd, $J=8.6,6.5$, $1.8 \mathrm{~Hz}, 2 \mathrm{H}), 2.71-2.62(\mathrm{~m}, 2 \mathrm{H}), 2.01(\mathrm{t}, J=2.6 \mathrm{~Hz}, 1 \mathrm{H}), 1.86(\mathrm{~d}, J=1.4$ $\mathrm{Hz}, 3 \mathrm{H})$.

${ }^{13} \mathrm{C}$ NMR $\left(126 \mathrm{MHz}, \mathrm{CDCl}_{3}\right): \delta=199.6,165.8,141.4,135.7,134.3$, 133.0, 132.7, 130.5, 130.0, 129.8 (2 C), 129.8, 128.6, 128.5, 128.5 (2 C), 127.9, 126.8, 124.0, 123.6, 79.9, 70.6, 69.5, 37.2, 27.6, 25.4, 23.6.

HRMS (ESI+): $m / z[\mathrm{M}+\mathrm{Na}]^{+}$calcd for $\mathrm{C}_{27} \mathrm{H}_{24} \mathrm{O}_{3} \mathrm{Na}$ : 419.1618; found: 419.1613.

\section{Cyclization of Aldehydes and Ketones; General Procedure}

A round-bottom flask was charged with the oxo-enyne substrate $\mathbf{7}$ and the flask was placed in a glovebox. In the glovebox, the substrate was dissolved in toluene $(0.01 \mathrm{M}$ solution) and a stock solution of
[JohnPhosAu(NCMe)] $\mathrm{SbF}_{6}$ complex [ $5 \mathrm{~mol} \%$ in $\mathrm{CH}_{2} \mathrm{Cl}_{2}$ (1/35 volume of toluene)] was added in one portion to the vigorously stirred solution. The resulting mixture was stirred at $25{ }^{\circ} \mathrm{C}$ for the indicated time. It was then removed from the glovebox and quenched by addition of QuadraPure $^{\mathrm{TM}}$ resin (ca. $10 \mathrm{mg}$ per $0.1 \mathrm{mmol}$ ) and the suspension stirred vigorously for $15-60 \mathrm{~min}$. It was then filtered on a sintered funnel and the volatiles were removed in vacuo. The crude material was redissolved in $\mathrm{CDCl}_{3}$ and the internal standard added to measure the NMR yields and diastereomeric ratios. All the material was then collected and purified according to the details provided for each compound below.

$\left(1 S^{*}, 3 a S^{*}, 4 S^{*}, 7 R^{*}, 7 a S^{*}\right)-7-M e t h y l-3 a, 4,5,6,7,7 a-h e x a h y d r o-1 H-4,7-$ epoxyinden-1-yl Benzoate (syn-8a)

Performed on $0.21 \mathrm{mmol}$ scale from $(E)-7 a$ (59 mg) with stirring for $16 \mathrm{~h}$ at $25^{\circ} \mathrm{C}$. Crude ${ }^{1} \mathrm{H}$ NMR yield $=81 \%$ (83:8 dr, ca. 10:1). Purified by preparative silica gel TLC eluting with cyclohexane $/ \mathrm{CH}_{2} \mathrm{Cl}_{2} / \mathrm{EtOAC}$ $(80: 15: 5)$ and isolated as a pale yellow solid $(48.8 \mathrm{mg}, 0.181 \mathrm{mmol}$, $83 \%, 93: 7 d r)$.

Mp $81-83{ }^{\circ} \mathrm{C}$ (pentane).

${ }^{1} \mathrm{H}$ NMR $\left(400 \mathrm{MHz}, \mathrm{CDCl}_{3}\right): \delta=8.05-8.00(\mathrm{~m}, 2 \mathrm{H}), 7.58-7.52(\mathrm{~m}, 1 \mathrm{H})$, 7.46-7.40 (m, $2 \mathrm{H}), 6.07$ (ddd, $J=5.7,2.2,1.0 \mathrm{~Hz}, 1 \mathrm{H}), 5.92(\mathrm{dtd}, J=$ 5.7, 2.1, 0.6 Hz, $1 \mathrm{H}), 5.77(\mathrm{tt}, J=2.5,1.2 \mathrm{~Hz}, 1 \mathrm{H}), 4.58-4.53(\mathrm{~m}, 1 \mathrm{H})$, 3.64-3.57 (m, $1 \mathrm{H}), 2.55$ (dddd, $J=9.2,2.3,1.4,0.6 \mathrm{~Hz}, 1 \mathrm{H}), 1.74-1.62$ (m, $2 \mathrm{H}), 1.61$ (s, $3 \mathrm{H}), 1.57-1.49$ (m, $1 \mathrm{H}), 1.45-1.35(\mathrm{~m}, 1 \mathrm{H})$.

${ }^{13} \mathrm{C}$ NMR $\left(101 \mathrm{MHz}, \mathrm{CDCl}_{3}\right): \delta=166.7,139.9,133.1,130.9,130.5$, 129.8 (2 C), 128.5 (2 C), 85.8, 79.9, 78.9, 59.4, 56.2, 30.9, 28.5, 21.4 .

HRMS (ESI+): $m / z[\mathrm{M}+\mathrm{Na}]^{+}$calcd for $\mathrm{C}_{17} \mathrm{H}_{18} \mathrm{O}_{3} \mathrm{Na}$ : 293.1148; found: 293.1151.

$\left(1 S^{*}, 3 \mathrm{a} S^{*}, 4 R^{*}, 7 S^{*}, 7 \mathrm{a} S^{*}\right)-7-M e t h y l-3 a, 4,5,6,7,7 a-h e x a h y d r o-1 H-4,7-$ epoxyinden-1-yl Benzoate (anti-8a)

Performed on $0.37 \mathrm{mmol}$ scale from $(Z)-7 \mathbf{a}(100 \mathrm{mg})$ with stirring for $6 \mathrm{~h}$ at $25^{\circ} \mathrm{C}$. Crude ${ }^{1} \mathrm{H}$ NMR yield $=91 \%$ (91:9 dr, yield of combined diastereomers). Purified by preparative silica gel TLC eluting with cyclohexane $/ \mathrm{CH}_{2} \mathrm{Cl}_{2} / \mathrm{EtOAc}(80: 15: 5)$ and isolated as a pale yellow oil (82 $\mathrm{mg}, 0.30 \mathrm{mmol}, 82 \%, 97: 3 \mathrm{dr}$ ). This compound was crystallized from $\mathrm{CH}_{2} \mathrm{Cl}_{2}$ /pentane to obtain single crystals suitable for X-ray diffraction (see Supporting Information).

Mp $75-77^{\circ} \mathrm{C}\left(\mathrm{CH}_{2} \mathrm{Cl}_{2} /\right.$ pentane $)$.

${ }^{1} \mathrm{H} \mathrm{NMR}\left(500 \mathrm{MHz}, \mathrm{CDCl}_{3}\right.$ ): $\delta=8.05-7.99(\mathrm{~m}, 2 \mathrm{H}), 7.54$ (ddt, $J=7.9$, $6.9,1.3 \mathrm{~Hz}, 1 \mathrm{H}$ ), 7.45-7.39 (m, $2 \mathrm{H}$ ), 6.00 (ddd, $J=5.5,2.2,0.9 \mathrm{~Hz}, 1 \mathrm{H}$ ), 5.97-5.92 (m, $2 \mathrm{H}), 4.19(\mathrm{~d}, J=5.1 \mathrm{~Hz}, 1 \mathrm{H}), 3.15(\mathrm{dq}, J=6.5,2.1 \mathrm{~Hz}, 1$ $\mathrm{H}), 2.32(\mathrm{dd}, J=6.9,1.7 \mathrm{~Hz}, 1 \mathrm{H}), 1.87(\mathrm{ddt}, J=12.9,11.3,5.4 \mathrm{~Hz}, 1 \mathrm{H})$, $1.68(\mathrm{~s}, 3 \mathrm{H}), 1.65-1.51(\mathrm{~m}, 3 \mathrm{H})$.

${ }^{13} \mathrm{C}$ NMR $\left(126 \mathrm{MHz}, \mathrm{CDCl}_{3}\right): \delta=166.3,137.7,133.0,131.6,130.6$, 129.7 (2 C), 128.4 (2 C), 84.5, 81.9, 78.1, 57.5, 56.2, 36.5, 31.1, 18.4 .

HRMS (ESI+): $m / z[\mathrm{M}+\mathrm{Na}]^{+}$calcd for $\mathrm{C}_{17} \mathrm{H}_{18} \mathrm{O}_{3} \mathrm{Na}$ : 293.1148; found: 293.1157.

tert-Butyldimethyl $\left\{\left[\left(1 S^{*}, 3 a S^{*}, 4 S^{*}, 7 R^{*}, 7 a S^{*}\right)-7-m e t h y l-\right.\right.$ 3a,4,5,6,7,7a-hexahydro-1H-4,7-epoxyinden-1-yl]oxy\}silane (syn8b)

Performed on $0.203 \mathrm{mmol}$ scale from $(E)-\mathbf{7 b}(57 \mathrm{mg})$ with stirring for $16 \mathrm{~h}$ at $25^{\circ} \mathrm{C}$. Crude ${ }^{1} \mathrm{H}$ NMR yield $=82 \%(99: 1 \mathrm{dr}$ ). Purified by silica gel column chromatography eluting with cyclohexane $/ \mathrm{CH}_{2} \mathrm{Cl}_{2} / \mathrm{EtOAc}$ $(80: 15: 5)$ and isolated as a pale yellow oil $(47.7 \mathrm{mg}, 0.170 \mathrm{mmol}, 82 \%$ $>99: 1 d r)$. 
${ }^{1} \mathrm{H} \mathrm{NMR}\left(500 \mathrm{MHz}, \mathrm{CDCl}_{3}\right): \delta=5.81(\mathrm{ddd}, J=5.6,2.2,0.9 \mathrm{~Hz}, 1 \mathrm{H}), 5.71$ $(\mathrm{dt}, J=5.7,2.0 \mathrm{~Hz}, 1 \mathrm{H}), 4.62-4.59(\mathrm{~m}, 1 \mathrm{H}), 4.47(\mathrm{t}, J=5.6 \mathrm{~Hz}, 1 \mathrm{H})$, 3.56-3.51 (m, $1 \mathrm{H}), 2.35(\mathrm{dt}, J=9.3,1.7 \mathrm{~Hz}, 1 \mathrm{H}), 1.64-1.53(\mathrm{~m}, 1 \mathrm{H})$, 1.51 (s, $3 \mathrm{H}$ ), 1.49-1.41 (m, $2 \mathrm{H}), 1.32-1.23$ ( $\mathrm{m}, 1 \mathrm{H}), 0.88$ (s, $9 \mathrm{H}), 0.08$ (s, $3 \mathrm{H}), 0.08(\mathrm{~s}, 3 \mathrm{H})$.

${ }^{13} \mathrm{C}$ NMR $\left(126 \mathrm{MHz}, \mathrm{CDCl}_{3}\right): \delta=136.0,134.8,85.6,79.1,76.9,62.6$, 56.0, 30.8, 28.4, 26.1 (3 C), 21.7, 18.3, -4.1, -4.3.

HRMS (APCI+): $m / z[\mathrm{M}+\mathrm{H}]^{+}$calcd for $\mathrm{C}_{16} \mathrm{H}_{29} \mathrm{O}_{2} \mathrm{Si}: 281.1931$; found: 281.1929.

\section{tert-Butyldimethyl $\left\{\left[\left(1 S^{*}, 3 a S^{*}, 4 R^{*}, 7 S^{*}, 7 a S^{*}\right)-7-m e t h y l-\right.\right.$ 3a,4,5,6,7,7a-hexahydro-1H-4,7-epoxyinden-1-yl]oxy\}silane (anti- 8b)}

Performed on $0.37 \mathrm{mmol}$ scale from $(Z)-7 \mathbf{b}(104 \mathrm{mg})$ by addition of solid [JohnPhosAu(NCMe)SbF 6 ] (5 mol\%) to a toluene solution $(0.01$ M) of $(Z)-7 \mathbf{b}$, with stirring for $14 \mathrm{~h}$ at $25^{\circ} \mathrm{C}$. Crude ${ }^{1} \mathrm{H}$ NMR yield $=73 \%$ (83:17 $d r$, yield of combined diastereomers). Purified by silica gel column chromatography eluting with pentane/ $\mathrm{Et}_{2} \mathrm{O}(95: 5)$ and isolated as a pale yellow oil (57 mg, $0.20 \mathrm{mmol}, 58 \%,>98: 2 \mathrm{dr}$ ) [minor diastereomer syn-8b (12 $\mathrm{mg}$ ) was also isolated, $12 \%]$.

${ }^{1} \mathrm{H}$ NMR $\left(400 \mathrm{MHz}, \mathrm{CDCl}_{3}\right): \delta=5.76($ app s, $2 \mathrm{H}), 4.80-4.76(\mathrm{~m}, 1 \mathrm{H})$, $4.10(\mathrm{~d}, J=5.0 \mathrm{~Hz}, 1 \mathrm{H}), 3.05(\mathrm{dd}, J=6.9,2.3 \mathrm{~Hz}, 1 \mathrm{H}), 2.09$ (dd, $J=6.9$, $2.0 \mathrm{~Hz}, 1 \mathrm{H}), 1.85-1.75(\mathrm{~m}, 1 \mathrm{H}), 1.63-1.46(\mathrm{~m}, 6 \mathrm{H}), 0.89$ (s, $9 \mathrm{H}), 0.10$ (s, $3 \mathrm{H}), 0.08(\mathrm{~s}, 3 \mathrm{H})$.

${ }^{13} \mathrm{C}$ NMR $\left(101 \mathrm{MHz}, \mathrm{CDCl}_{3}\right): \delta=135.8,133.8,84.3,79.2,78.6,59.8$, $57.3,36.5,31.2,26.0$ (3 C), 18.6, 18.2, -3.9, -4.3.

HRMS (ESI+): $m / z$ [M $+\mathrm{Na}]^{+}$calcd for $\mathrm{C}_{16} \mathrm{H}_{28} \mathrm{O}_{2} \mathrm{SiNa}$ : 303.1751; found: 303.1748.

\section{$\left(1 S^{*}, 3 a S^{*}, 4 S^{*}, 7 R^{*}, 7 a S^{*}\right)-1-($ Methoxymethoxy)-7-methyl- 3a,4,5,6,7,7a-hexahydro-1H-4,7-epoxyindene (syn-8k)}

Performed on $0.20 \mathrm{mmol}$ scale from $(E)-7 \mathbf{k}(42 \mathrm{mg})$ with stirring for $24 \mathrm{~h}$ at $40{ }^{\circ} \mathrm{C}$. Crude ${ }^{1} \mathrm{H}$ NMR yield $=82 \%(>99: 1 \mathrm{dr})$. Purified by silica gel column chromatography eluting with cyclohexane $/ \mathrm{CH}_{2} \mathrm{Cl}_{2} / \mathrm{EtOAc}$ $(80: 15: 5)$ and isolated as a pale yellow oil $(33.9 \mathrm{mg}, 0.161 \mathrm{mmol}, 81 \%$, $>99: 1 d r)$.

${ }^{1} \mathrm{H} \mathrm{NMR}\left(500 \mathrm{MHz}, \mathrm{CDCl}_{3}\right): \delta=5.91(\mathrm{ddd}, J=5.7,2.2,1.1 \mathrm{~Hz}, 1 \mathrm{H}), 5.82$ (dt, $J=5.7,2.3 \mathrm{~Hz}, 1 \mathrm{H}), 4.68-4.63(\mathrm{~m}, 2 \mathrm{H}), 4.51-4.47$ (m, $2 \mathrm{H}), 3.54-$ $3.48(\mathrm{~m}, 1 \mathrm{H}), 3.35(\mathrm{~s}, 3 \mathrm{H}), 2.43(\mathrm{dt}, J=9.4,1.9 \mathrm{~Hz}, 1 \mathrm{H}), 1.64-1.57(\mathrm{~m}$, $1 \mathrm{H}), 1.51(\mathrm{~s}, 3 \mathrm{H}), 1.50-1.43(\mathrm{~m}, 2 \mathrm{H}), 1.32-1.25(\mathrm{~m}, 1 \mathrm{H})$.

${ }^{13} \mathrm{C}$ NMR $\left(126 \mathrm{MHz}, \mathrm{CDCl}_{3}\right): \delta=137.9,132.4,95.3,85.5,81.4,79.1$, 59.7, 55.9, 55.3, 30.7, 28.4, 21.1.

HRMS (ESI+): $m / z[\mathrm{M}+\mathrm{Na}]^{+}$calcd for $\mathrm{C}_{12} \mathrm{H}_{18} \mathrm{O}_{3} \mathrm{Na}$ : 233.1148; found: 233.1143.

\section{Triethyl $\left\{\left[\left(1 S^{*}, 3 a S^{*}, 4 S^{*}, 7 R^{*}, 7 a S^{*}\right)-7-m e t h y l-3 a, 4,5,6,7,7 a-h e x a h y-\right.\right.$} dro-1H-4,7-epoxyinden-1-yl]oxy\}silane (syn-81)

Performed on $0.20 \mathrm{mmol}$ scale from $(E)-71$ (56 mg) with stirring for $44 \mathrm{~h}$ at $25^{\circ} \mathrm{C}$. Crude ${ }^{1} \mathrm{H}$ NMR yield $=84 \%(95: 5 d r)$. Purified by silica gel column chromatography eluting with cyclohexane $/ \mathrm{CH}_{2} \mathrm{Cl}_{2} / \mathrm{EtOAc}$ $(80: 15: 5)$ and isolated as a pale yellow oil $(39.7 \mathrm{mg}, 0.142 \mathrm{mmol}, 71 \%$, $>99: 1 d r)$.

${ }^{1} \mathrm{H}$ NMR $\left(500 \mathrm{MHz}, \mathrm{CDCl}_{3}\right): \delta=5.83(\mathrm{ddd}, J=5.6,2.2,0.9 \mathrm{~Hz}, 1 \mathrm{H}), 5.72$ $(\mathrm{dtd}, J=5.7,2.0,0.6 \mathrm{~Hz}, 1 \mathrm{H}), 4.58(\mathrm{app} t \mathrm{tt}, J=2.3,1.2 \mathrm{~Hz}, 1 \mathrm{H}), 4.48(\mathrm{t}$, $J=5.7 \mathrm{~Hz}, 1 \mathrm{H}), 3.58-3.52(\mathrm{~m}, 1 \mathrm{H}), 2.37(\mathrm{~d}, J=9.3 \mathrm{~Hz}, 1 \mathrm{H}), 1.65-1.55$ (m, $1 \mathrm{H}), 1.52(\mathrm{~s}, 3 \mathrm{H}), 1.50-1.40(\mathrm{~m}, 2 \mathrm{H}), 1.33-1.26(\mathrm{~m}, 1 \mathrm{H}), 0.96(\mathrm{t}$, $J=7.9 \mathrm{~Hz}, 9 \mathrm{H}), 0.61(\mathrm{q}, J=7.9 \mathrm{~Hz}, 6 \mathrm{H})$.
${ }^{13} \mathrm{C}$ NMR $\left(101 \mathrm{MHz}, \mathrm{CDCl}_{3}\right): \delta=136.2,134.7,85.6,79.1,76.5,62.5$, $55.9,30.8,28.5,21.6,6.9$ (3 C), 5.0 (3 C).

HRMS (ESI+): $m / z$ [M + Na] $]^{+}$calcd for $\mathrm{C}_{16} \mathrm{H}_{28} \mathrm{O}_{2} \mathrm{SiNa}$ : 303.1751; found: 303.1751.

$\left(1 S^{*}, 3 a S^{*}, 4 S^{*}, 7 R^{*}, 7 a S^{*}\right)-4,7-D i m e t h y l-3 a, 4,5,6,7,7 a-h e x a h y d r o-1 H-$ 4,7-epoxyinden-1-yl Benzoate (syn-8c)

Performed on $0.2 \mathrm{mmol}$ scale from $(E)-7 \mathrm{c}(56 \mathrm{mg})$ with stirring for 17 h at $30^{\circ} \mathrm{C}$. Crude ${ }^{1} \mathrm{H}$ NMR yield $=87 \%$ (89:11 $d r$, yield of combined diastereomers). Purified by preparative silica gel TLC eluting with cyclohexane $/ \mathrm{CH}_{2} \mathrm{Cl}_{2} / \mathrm{EtOAc}(80: 15: 5)$ and isolated as a pale yellow oil (44 $\mathrm{mg}, 0.154 \mathrm{mmol}, 78 \%, 88: 12 \mathrm{dr}$ ). Further purification by preparative silica gel TLC eluting twice with cyclohexane $/ \mathrm{CH}_{2} \mathrm{Cl}_{2} / \mathrm{EtOAc}(80: 15: 5)$ resulted in the isolation of a pale yellow oil $(20.2 \mathrm{mg}, 0.071 \mathrm{mmol}$, $36 \%,>99: 1 d r)$.

${ }^{1} \mathrm{H}$ NMR $\left(500 \mathrm{MHz}, \mathrm{CDCl}_{3}\right): \delta=8.04-8.01(\mathrm{~m}, 2 \mathrm{H}), 7.56-7.52(\mathrm{~m}, 1 \mathrm{H})$, $7.45-7.40(\mathrm{~m}, 2 \mathrm{H}), 6.06$ (ddd, $J=5.6,2.2,1.0 \mathrm{~Hz}, 1 \mathrm{H}), 5.92(\mathrm{dtd}, J=$ 5.6, 2.1, 0.6 Hz, $1 \mathrm{H}$ ), $5.77(\mathrm{tt}, J=2.4,1.2 \mathrm{~Hz}, 1 \mathrm{H}$ ), 3.28 (d quin, $J=9.2$, $2.0 \mathrm{~Hz}, 1 \mathrm{H}), 2.65(\mathrm{dt}, J=9.3,1.8 \mathrm{~Hz}, 1 \mathrm{H}), 1.72-1.66(\mathrm{~m}, 1 \mathrm{H}), 1.64-$ $1.57(\mathrm{~m}, 1 \mathrm{H}), 1.56(\mathrm{~s}, 3 \mathrm{H}), 1.53(\mathrm{ddd}, J=12.1,3.4,2.2 \mathrm{~Hz}, 1 \mathrm{H}), 1.50(\mathrm{~s}$, $3 \mathrm{H}), 1.48-1.43(\mathrm{~m}, 1 \mathrm{H})$.

${ }^{13} \mathrm{C}$ NMR $\left(101 \mathrm{MHz}, \mathrm{CDCl}_{3}\right): \delta=166.6,139.7,133.0,130.8,130.6$, 129.7 (2 C), 128.4 (2 C), 85.9, 85.5, 80.5, 61.8, 60.5, 34.6, 32.6, 21.8, 21.6.

HRMS (ESI+): $m / z$ [M + Na] calcd for $\mathrm{C}_{18} \mathrm{H}_{20} \mathrm{O}_{3} \mathrm{Na}$ : 307.1305; found: 307.1297.

$\left(1 S^{*}, 3 \mathrm{a} S^{*}, 4 R^{*}, 7 S^{*}, 7 \mathrm{a} S^{*}\right)-4,7-D i m e t h y l-3 a, 4,5,6,7,7 \mathrm{a}-h e x a h y d r o-1 H-$ 4,7-epoxyinden-1-yl Benzoate (anti-8c)

Performed on $0.25 \mathrm{mmol}$ scale from $(Z)-7 \mathrm{c}(71 \mathrm{mg})$ with stirring for $18 \mathrm{~h}$ at $25^{\circ} \mathrm{C}$. Crude ${ }^{1} \mathrm{H}$ NMR yield $=89 \%$ (83:17 dr, yield of combined diastereomers). Purified by column chromatography on silica gel eluting with cyclohexane $/ \mathrm{CH}_{2} \mathrm{Cl}_{2} / \mathrm{EtOAc}(80: 15: 5)$ and isolated as a pale yellow solid (56 mg, $0.197 \mathrm{mmol}, 79 \%, 83: 17 \mathrm{dr}$ ). Further crystallization from $\mathrm{Et}_{2} \mathrm{O} /$ pentane afforded $39 \mathrm{mg}$ of a colorless solid $(55 \%, \geq 98: 2$ $d r$ ) (plus $17 \mathrm{mg}$ of a pale yellow oil, 24\%, 56:44 dr).

Mp 79-81 ${ }^{\circ} \mathrm{C}\left(\mathrm{Et}_{2} \mathrm{O} /\right.$ pentane).

${ }^{1} \mathrm{H}$ NMR $\left(500 \mathrm{MHz}, \mathrm{CDCl}_{3}\right): \delta=8.05-8.00(\mathrm{~m}, 2 \mathrm{H}), 7.54$ (ddt, $J=7.8$, 6.9, $1.3 \mathrm{~Hz}, 1 \mathrm{H}), 7.45-7.39$ ( $\mathrm{m}, 2 \mathrm{H}), 6.02-5.98$ ( $\mathrm{m}, 2 \mathrm{H}), 5.98-5.95$ (m, $1 \mathrm{H}), 3.13-3.08(\mathrm{~m}, 1 \mathrm{H}), 2.43(\mathrm{dd}, J=6.8,1.9 \mathrm{~Hz}, 1 \mathrm{H}), 1.74-1.60(\mathrm{~m}, 7$ $\mathrm{H}), 1.38$ (s, $3 \mathrm{H})$.

${ }^{13} \mathrm{C}$ NMR $\left(126 \mathrm{MHz}, \mathrm{CDCl}_{3}\right): \delta=166.3,136.5,133.0,132.2,130.7$, 129.7 (2 C), 128.4 (2 C), 84.3, 84.2, 82.1, 60.0, 57.7, 38.6, 38.1, 18.8, 18.5 .

HRMS (ESI+): $m / z[\mathrm{M}+\mathrm{Na}]^{+}$calcd for $\mathrm{C}_{18} \mathrm{H}_{20} \mathrm{O}_{3} \mathrm{Na}$ : 307.1305; found: 307.1298 .

tert-Butyl $\left\{\left[\left(1 S^{*}, 3 a S^{*}, 4 S^{*}, 7 R^{*}, 7 a S^{*}\right)-4,7-d i m e t h y l-3 a, 4,5,6,7,7 a-\right.\right.$ hexahydro-1H-4,7-epoxyinden-1-yl]oxy\}dimethylsilane (syn-8d) Performed on $0.217 \mathrm{mmol}$ scale from $(E)-7 \mathbf{d}(64 \mathrm{mg})$ with stirring for $17 \mathrm{~h}$ at $25^{\circ} \mathrm{C}$. Crude ${ }^{1} \mathrm{H}$ NMR yield $=97 \%(>99: 1 \mathrm{dr})$. The product was further purified by silica gel column chromatography eluting with cyclohexane $/ \mathrm{CH}_{2} \mathrm{Cl}_{2} / \mathrm{EtOAc}(80: 15: 5)$ and isolated as a pale yellow oil (41.4 mg, $0.141 \mathrm{mmol}, 65 \%$, >99:1 dr).

${ }^{1} \mathrm{H}$ NMR $\left(500 \mathrm{MHz}, \mathrm{CDCl}_{3}\right): \delta=5.81(\mathrm{ddd}, J=5.6,2.2,0.9 \mathrm{~Hz}, 1 \mathrm{H}), 5.71$ $(\mathrm{dtd}, J=5.6,2.0,0.6 \mathrm{~Hz}, 1 \mathrm{H}), 4.61-4.60(\mathrm{~m}, 1 \mathrm{H}), 3.22(\mathrm{dd}, J=9.5,2.0$ $\mathrm{Hz}, 1 \mathrm{H}), 2.46(\mathrm{~d}, J=9.4 \mathrm{~Hz}, 1 \mathrm{H}), 1.55-1.50(\mathrm{~m}, 2 \mathrm{H}), 1.47(\mathrm{~s}, 3 \mathrm{H}), 1.45$ (s, $3 \mathrm{H}), 1.41-1.37$ (m, $2 \mathrm{H}), 0.88$ (s, $9 \mathrm{H}), 0.08$ (s, $3 \mathrm{H}), 0.08$ (s, $3 \mathrm{H})$. 
${ }^{13} \mathrm{C}$ NMR $\left(126 \mathrm{MHz}, \mathrm{CDCl}_{3}\right): \delta=135.9,134.7,86.0,85.3,77.6,63.8$, 61.6, 34.6, 32.5, 26.1 (3 C), 21.9, 21.8, 18.3, -4.1, -4.2.

HRMS (ESI+): $m / z[\mathrm{M}+\mathrm{Na}]^{+}$calcd for $\mathrm{C}_{17} \mathrm{H}_{30} \mathrm{O}_{2} \mathrm{SiNa}$ : 317.1907 ; found: 317.1896.

\section{tert-Butyl $\left\{\left[\left(1 S^{*}, 3 a S^{*}, 4 R^{*}, 7 S^{*}, 7 a S^{*}\right)-4,7-d i m e t h y l-3 a, 4,5,6,7,7 a-\right.\right.$ hexahydro-1H-4,7-epoxyinden-1-yl]oxy\}dimethylsilane (anti-8d)} Performed on $0.3 \mathrm{mmol}$ scale from $(Z)-7 \mathbf{d}(88 \mathrm{mg})$ with stirring for 18 h at $25^{\circ} \mathrm{C}$. Crude ${ }^{1} \mathrm{H}$ NMR yield $=74 \%(>98: 2 \mathrm{dr})$. Purified by silica gel column chromatography eluting with pentane/ $\mathrm{Et}_{2} \mathrm{O}(95: 5)$ and isolated as a pale yellow oil (62 mg, $0.211 \mathrm{mmol}, 70 \%,>98: 2 d r$ ).

${ }^{1} \mathrm{H}$ NMR $\left(500 \mathrm{MHz}, \mathrm{CDCl}_{3}\right): \delta=5.79(\mathrm{dt}, J=5.7,1.9 \mathrm{~Hz}, 1 \mathrm{H}), 5.74$ (ddd, $J=5.7,2.4,1.2 \mathrm{~Hz}, 1 \mathrm{H}), 4.80(\mathrm{dq}, J=2.2,1.1 \mathrm{~Hz}, 1 \mathrm{H}), 3.00(\mathrm{dq}, J=6.7$, $2.0 \mathrm{~Hz}, 1 \mathrm{H}), 2.18$ (dd, $J=7.1,2.2 \mathrm{~Hz}, 1 \mathrm{H}), 1.71-1.53(\mathrm{~m}, 4 \mathrm{H}), 1.51(\mathrm{~s}, 3$ $\mathrm{H}), 1.31(\mathrm{~s}, 3 \mathrm{H}), 0.88$ (s, $9 \mathrm{H}), 0.09$ (s $3 \mathrm{H}), 0.08$ (s, $3 \mathrm{H})$.

${ }^{13} \mathrm{C}$ NMR $\left(126 \mathrm{MHz}, \mathrm{CDCl}_{3}\right): \delta=136.4,132.5,84.5,84.1,79.4,61.4$, 59.7, 38.5, 38.2, 26.0 (3 C), 18.9, 18.5, 18.2, -3.9, -4.3.

HRMS (ESI+): $m / z[\mathrm{M}+\mathrm{Na}]^{+}$calcd for $\mathrm{C}_{17} \mathrm{H}_{30} \mathrm{O}_{2} \mathrm{SiNa}$ : 317.1907; found: 317.1904.

\section{$\left(1 S^{*}, 3 \mathrm{a} S^{*}, 4 R^{*}, 7 R^{*}, 7 \mathrm{a} S^{*}\right)-4-C y c l o p r o p y l-7-m e t h y l-3 a, 4,5,6,7,7 \mathrm{a}-$ hexahydro-1H-4,7-epoxyinden-1-yl Benzoate (syn-8e)}

Performed on $0.2 \mathrm{mmol}$ scale from $(E)-7 e(62 \mathrm{mg})$ with stirring for 15 h at $25{ }^{\circ} \mathrm{C}$. Crude ${ }^{1} \mathrm{H}$ NMR yield $=54 \%$ (80:20 dr, yield of combined diastereomers, $77 \%$ conversion). Purified by preparative silica gel TLC eluting with cyclohexane $/ \mathrm{CH}_{2} \mathrm{Cl}_{2} / \mathrm{EtOAc}(85: 15: 5)$ and isolated as a pale yellow oil ( $32 \mathrm{mg}, 0.103 \mathrm{mmol}, 52 \%, 82: 18 \mathrm{dr}$ ).

${ }^{1} \mathrm{H} \mathrm{NMR}\left(500 \mathrm{MHz}, \mathrm{CDCl}_{3}\right): \delta=8.05-7.99(\mathrm{~m}, 2 \mathrm{H}+2 \mathrm{H}$ minor $), 7.57-$ $7.51(\mathrm{~m}, 1 \mathrm{H}+1 \mathrm{H}$ minor), 7.45-7.40 ( $\mathrm{m}, 2 \mathrm{H}+2 \mathrm{H}$ minor), 6.05 (ddd, $J=5.7,2.1,1.0 \mathrm{~Hz}, 1 \mathrm{H}), 5.93-5.89(\mathrm{~m}, 1 \mathrm{H}), 5.76(\mathrm{tt}, J=2.4,1.2 \mathrm{~Hz}, 1$ $\mathrm{H}), 3.30$ (d quin, $J=9.0,2.1 \mathrm{~Hz}, 1 \mathrm{H}), 2.62(\mathrm{dt}, J=9.3,1.7 \mathrm{~Hz}, 1 \mathrm{H}), 1.70-$ $1.62(\mathrm{~m}, 1 \mathrm{H}+1 \mathrm{H}$ minor), $1.54(\mathrm{~s}, 3 \mathrm{H}), 1.50-1.34(\mathrm{~m}, 3 \mathrm{H}+3 \mathrm{H} \mathrm{mi}-$ nor), $1.24-1.16(\mathrm{~m}, 1 \mathrm{H}), 0.60-0.52(\mathrm{~m}, 2 \mathrm{H}+1 \mathrm{H}$ minor $), 0.53-0.46$ ( $\mathrm{m}, 1 \mathrm{H}+2 \mathrm{H}$ minor $), 0.45-0.37(\mathrm{~m}, 1 \mathrm{H})$.

${ }^{13} \mathrm{C}$ NMR (101 MHz, $\mathrm{CDCl}_{3}$ ): $\delta=166.6,140.3,133.0,130.7,129.7$ (2 C), 128.5 (2 C), 88.8, 84.9, 80.3, 60.1, 59.8, 31.8, 31.2, 21.6, 14.9, 1.5, 1.5; 1 $\mathrm{C}$ could not be detected due to overlap of signals.

HRMS (ESI+): $m / z[\mathrm{M}+\mathrm{Na}]^{+}$calcd for $\mathrm{C}_{20} \mathrm{H}_{22} \mathrm{O}_{3} \mathrm{Na}$ : 333.1461; found: 333.1464.

\section{$\left(1 S^{*}, 3 a S^{*}, 4 S^{*}, 7 S^{*}, 7 a S^{*}\right)-4-C y c l o p r o p y l-7-m e t h y l-3 a, 4,5,6,7,7 a-$ hexahydro-1H-4,7-epoxyinden-1-yl Benzoate (anti-8e)}

Performed on $0.2 \mathrm{mmol}$ scale from $(Z)-7 e(62 \mathrm{mg})$ with stirring for 18 $\mathrm{h}$ at $25^{\circ} \mathrm{C}$. Crude ${ }^{1} \mathrm{H}$ NMR yield $=83 \%$ (87:13 $d r$, yield of combined diastereomers). Purified by preparative silica gel TLC eluting with cyclohexane $/ \mathrm{CH}_{2} \mathrm{Cl}_{2} / \mathrm{EtOAc}(85: 12: 3)$ and isolated as a pale yellow oil (46 mg, $0.148 \mathrm{mmol}, 74 \%, 89: 11 \mathrm{dr}$ ).

${ }^{1} \mathrm{H}$ NMR $\left(500 \mathrm{MHz}, \mathrm{CDCl}_{3}\right): \delta=8.05-8.00(\mathrm{~m}, 2 \mathrm{H}+2 \mathrm{H}$ minor $), 7.57-$ 7.52 ( $\mathrm{m}, 1 \mathrm{H}+1 \mathrm{H}$ minor), 7.45-7.40 ( $\mathrm{m}, 2 \mathrm{H}+2 \mathrm{H}$ minor), 6.18 (app $\mathrm{dq}, J=4.9,2.2 \mathrm{~Hz}, 1 \mathrm{H}), 5.99-5.95(\mathrm{~m}, 2 \mathrm{H}), 3.22-3.18(\mathrm{~m}, 1 \mathrm{H}), 2.43$ $(\mathrm{dd}, J=6.9,1.8 \mathrm{~Hz}, 1 \mathrm{H}), 1.67(\mathrm{ddd}, J=12.0,9.2,5.0 \mathrm{~Hz}, 1 \mathrm{H}), 1.63-1.55$ ( $\mathrm{m}, 4 \mathrm{H}+3 \mathrm{H}$ minor), 1.46 (td, $J=11.7,4.9 \mathrm{~Hz}, 1 \mathrm{H}+2 \mathrm{H}$ minor $), 1.39$ (ddd, $J=11.6,9.2,4.8 \mathrm{~Hz}, 1 \mathrm{H}+1 \mathrm{H}$ minor), 1.08 (tt, $J=8.5,5.4 \mathrm{~Hz}, 1$ $\mathrm{H}), 0.60-0.54(\mathrm{~m}, 1 \mathrm{H}+2 \mathrm{H}$ minor $), 0.53-0.49(\mathrm{~m}, 2 \mathrm{H}), 0.33-0.28$ ( $\mathrm{m}$, $1 \mathrm{H})$.

${ }^{13} \mathrm{C}$ NMR $\left(126 \mathrm{MHz}, \mathrm{CDCl}_{3}\right): \delta=166.3,136.8,133.0,131.6,130.7$, 129.7 (2 C), 128.4 (2 C), 86.9, 83.7, 82.3, 60.6, 57.6, 37.6, 32.7, 18.7, $12.2,2.2,1.4$.
HRMS (ESI+): $m / z[\mathrm{M}+\mathrm{Na}]^{+}$calcd for $\mathrm{C}_{20} \mathrm{H}_{22} \mathrm{O}_{3} \mathrm{Na}$ : 333.1461 ; found: 333.1461.

$\left(1 S^{*}, 3 \mathrm{a} S^{*}, 4 S^{*}, 7 S^{*}, 7 \mathrm{a} S^{*}\right)-4-C y c l o p e n t y l-7-m e t h y l-3 a, 4,5,6,7,7 \mathrm{a}-$ hexahydro-1H-4,7-epoxyinden-1-yl Benzoate (anti-8f)

Performed on $0.2 \mathrm{mmol}$ scale from $(Z)-7 \mathbf{f}(68 \mathrm{mg})$ with stirring for 18 h at $25^{\circ} \mathrm{C}$. Crude ${ }^{1} \mathrm{H}$ NMR yield $=78 \%$ (84:16 dr, yield of combined diastereomers). Purified by preparative silica gel TLC eluting with cyclohexane $/ \mathrm{CH}_{2} \mathrm{Cl}_{2} / \mathrm{EtOAc}$ (85:12:3) and isolated as a pale yellow oil (46 $\mathrm{mg}, 0.136 \mathrm{mmol}, 68 \%, 85: 15 \mathrm{dr}$ ). Note: since the diastereomeric counterpart of this tricycle was not prepared, the distinguishable data for the minor diastereomer are also given below.

${ }^{1} \mathrm{H}$ NMR $\left(500 \mathrm{MHz}, \mathrm{CDCl}_{3}\right): \delta=8.04-8.00(\mathrm{~m}, 2 \mathrm{H}+2 \mathrm{H}$ minor), 7.577.51 ( $\mathrm{m}, 1 \mathrm{H}+1 \mathrm{H}$ minor), 7.45-7.39 ( $\mathrm{m}, 2 \mathrm{H}+2 \mathrm{H}$ minor), 6.07 (ddd, $J=5.6,2.2,1.0 \mathrm{~Hz}, 1 \mathrm{H}$ minor $), 6.06-6.03(\mathrm{~m}, 1 \mathrm{H}), 6.00-5.95(\mathrm{~m}, 2 \mathrm{H})$, 5.92-5.89 ( $\mathrm{m}, 1 \mathrm{H}$ minor), 5.76 (tt, $J=2.4,1.2 \mathrm{~Hz}, 1 \mathrm{H}$ minor), 3.403.35 ( $\mathrm{m}, 1 \mathrm{H}$ minor), 3.19 (td, $J=4.2,2.1 \mathrm{~Hz}, 1 \mathrm{H}), 2.68(\mathrm{dt}, J=9.2,1.7$ $\mathrm{Hz}, 1 \mathrm{H}$ minor), 2.44 (dd, $J=6.9,1.9 \mathrm{~Hz}, 1 \mathrm{H}$ ), 2.30 (app quin, $J=8.7 \mathrm{~Hz}$, $1 \mathrm{H}$ minor), 2.20 (quin, $J=8.1 \mathrm{~Hz}, 1 \mathrm{H}$ ), 1.86 (app ddq, $J=15.6,8.0,3.8$ $\mathrm{Hz}, 1 \mathrm{H}), 1.83-1.35$ (m, $13 \mathrm{H}+13 \mathrm{H}$ minor), $1.35-1.24(\mathrm{~m}, 1 \mathrm{H}+2 \mathrm{H}$ minor).

${ }^{13} \mathrm{C}$ NMR $\left(126 \mathrm{MHz}, \mathrm{CDCl}_{3}\right): \delta=166.3,136.6,132.9,132.0,130.7$, 129.7 (2 C), 128.4 (2 C), 89.7, 83.8, 82.3, 60.0, 57.6, 41.0, 37.9, 30.1, 28.9, 27.5, 26.4, 26.2, 18.8. [Signals for syn-8f: 166.6, 141.0, 133.0, 130.6, 129.7, 91.0, 84.6, 80.2, 60.4, 59.3, 45.0, 32.1, 30.6, 28.3, 28.1, 26.0, 21.6.]

HRMS (ESI+): $m / z[\mathrm{M}+\mathrm{Na}]^{+}$calcd for $\mathrm{C}_{22} \mathrm{H}_{26} \mathrm{O}_{3} \mathrm{Na}$ : 361.1774; found: 361.1774.

$\left(1 S^{*}, 3 \mathrm{a} S^{*}, 4 S^{*}, 7 R^{*}, 7 \mathrm{a} S^{*}\right)-7-M e t h y l-4-p h e n y l-3 a, 4,5,6,7,7 a-h e x a h y-$ dro-1H-4,7-epoxyinden-1-yl Benzoate (syn-8g)

Performed on $0.2 \mathrm{mmol}$ scale from $(E)-7 \mathrm{~g}$ (64 mg) with stirring for 15 $\mathrm{h}$ at $30{ }^{\circ} \mathrm{C}$. Crude ${ }^{1} \mathrm{H}$ NMR yield $=72 \%$ (58:42 dr, yield of combined diastereomers). Purified by preparative silica gel TLC eluting with cyclohexane $/ \mathrm{CH}_{2} \mathrm{Cl}_{2} /$ EtOAc $(80: 15: 5)$ and isolated as an off-white solid (26.1 mg, 0.075 mmol, 38\%, 57:43 dr).

Mp 94-98 ${ }^{\circ} \mathrm{C}$ (pentane).

${ }^{1} \mathrm{H}$ NMR $\left(500 \mathrm{MHz}, \mathrm{CDCl}_{3}\right): \delta=8.05-8.02(\mathrm{~m}, 2 \mathrm{H}+2 \mathrm{H}$ minor), $7.58-$ 7.53 ( $\mathrm{m}, 1 \mathrm{H}+1 \mathrm{H}$ minor), 7.45-7.41 ( $\mathrm{m}, 3 \mathrm{H}+2 \mathrm{H}$ minor), 7.39-7.35 (m, $2 \mathrm{H}), 7.34-7.32$ ( $\mathrm{m}, 1 \mathrm{H}+4 \mathrm{H}$ minor), 7.31-7.27 (m, $1 \mathrm{H}), 6.24$ (ddd, $J=5.6,2.2,1.0 \mathrm{~Hz}, 1 \mathrm{H}$ ), 6.03-6.00 ( $\mathrm{m}, 1 \mathrm{H}$ ), 5.85 (d quin, $J=2.5$, $1.2 \mathrm{~Hz}, 1 \mathrm{H}$ ), 3.59 (d quin, $J=9.2,2.1 \mathrm{~Hz}, 1 \mathrm{H}), 2.79$ (dt, $J=9.4,1.8 \mathrm{~Hz}, 1$ $\mathrm{H}), 2.10-2.02(\mathrm{~m}, 1 \mathrm{H}), 1.88-1.77(\mathrm{~m}, 2 \mathrm{H}+2 \mathrm{H}$ minor $), 1.68(\mathrm{~s}, 3 \mathrm{H})$, $1.67-1.61(\mathrm{~m}, 1 \mathrm{H})$.

${ }^{13} \mathrm{C}$ NMR $\left(101 \mathrm{MHz}, \mathrm{CDCl}_{3}\right): \delta=166.7,143.0,139.8,133.1,131.4$, 130.5, 129.8 (2 C), 128.5 (2 C), 128.5 (2 C), 127.4, 125.2 (2 C), 89.4, 85.7, 80.3, 63.2, 60.3, 35.0, 32.3, 21.7.

HRMS (ESI+): $m / z[\mathrm{M}+\mathrm{Na}]^{+}$calcd for $\mathrm{C}_{23} \mathrm{H}_{22} \mathrm{O}_{3} \mathrm{Na}$ : 369.1461; found: 369.1450.

$\left(1 S^{*}, 3 \mathrm{a} S^{*}, 4 R^{*}, 7 S^{*}, 7 \mathrm{a} S^{*}\right)-7-M e t h y l-4-p h e n y l-3 a, 4,5,6,7,7 \mathrm{a}-$ hexahydro-1H-4,7-epoxyinden-1-yl Benzoate (anti-8g)

Performed on $0.2 \mathrm{mmol}$ scale from $(Z)-7 \mathbf{g}(69 \mathrm{mg})$ with stirring for 14 $\mathrm{h}$ at $25^{\circ} \mathrm{C}$. Crude ${ }^{1} \mathrm{H}$ NMR yield $=90 \%$ (91:9 dr, yield of combined diastereomers). The product was purified by column chromatography on silica gel eluting with cyclohexane/EtOAc (95:5) and isolated as a colorless solid ( $61 \mathrm{mg}, 0.176 \mathrm{mmol}, 88 \%, 93: 7 \mathrm{dr}$ ). Further crystallization from $\mathrm{CH}_{2} \mathrm{Cl}_{2}(200 \mu \mathrm{L})+\mathrm{Et}_{2} \mathrm{O}(200 \mu \mathrm{L})+$ pentane $(1 \mathrm{~mL})$, first at $4{ }^{\circ} \mathrm{C}$ for $2 \mathrm{~h}$ then at $-30{ }^{\circ} \mathrm{C}$ for $24 \mathrm{~h}$, gave $30 \mathrm{mg}$ of colorless needles $(43 \%$, 
$>98: 2 d r)$. The filtrate was recrystallized from $\mathrm{CH}_{2} \mathrm{Cl}_{2}(100 \mu \mathrm{L})+\mathrm{Et}_{2} \mathrm{O}$ $(200 \mu \mathrm{L})+$ pentane $(1.2 \mathrm{~mL})$ to give a second crop of $18 \mathrm{mg}$ of colorless solid $(26 \%,>98: 2 d r)$. Overall yield after crystallization was $69 \%$ (>98:2 dr).

Mp $137-138^{\circ} \mathrm{C}\left(\mathrm{CH}_{2} \mathrm{Cl}_{2} / \mathrm{Et}_{2} \mathrm{O} /\right.$ pentane $)$.

${ }^{1} \mathrm{H}$ NMR $\left(400 \mathrm{MHz}, \mathrm{CDCl}_{3}\right): \delta=8.07-8.01(\mathrm{~m}, 2 \mathrm{H}), 7.58-7.52(\mathrm{~m}, 1 \mathrm{H})$, 7.47-7.40 (m, $2 \mathrm{H}), 7.37-7.30$ ( $\mathrm{m}, 4 \mathrm{H}), 7.29-7.22(\mathrm{~m}, 1 \mathrm{H}), 6.06$ (dt, J = 3.4, $1.7 \mathrm{~Hz}, 1 \mathrm{H}$ ), 5.89 (dt, $J=5.7,2.1 \mathrm{~Hz}, 1 \mathrm{H}$ ), 5.45 (ddd, $J=5.7,2.3,1.2$ $\mathrm{Hz}, 1 \mathrm{H}), 3.52(\mathrm{dq}, J=6.7,2.2 \mathrm{~Hz}, 1 \mathrm{H}), 2.55(\mathrm{dd}, J=6.7,1.8 \mathrm{~Hz}, 1 \mathrm{H})$, 2.24-2.15 (m, $1 \mathrm{H}), 1.97-1.79$ (m, $3 \mathrm{H}), 1.77$ (s, $3 \mathrm{H}$ ).

${ }^{13} \mathrm{C}$ NMR $\left(101 \mathrm{MHz}, \mathrm{CDCl}_{3}\right): \delta=166.3,140.9,137.2,133.0,131.5$, 130.6, 129.7 (2 C), 128.4 (2 C), 128.2 (2 C), 127.0, 125.4 (2 C), 87.9, $84.4,82.3,61.6,57.4,38.4,38.2,18.8$.

HRMS (ESI+): $m / z$ [M + Na] ${ }^{+}$calcd for $\mathrm{C}_{23} \mathrm{H}_{22} \mathrm{O}_{3} \mathrm{Na}$ : 369.1461; found: 369.1459 .

\section{tert-Butyldimethyl $\left\{\left[\left(1 S^{*}, 3 a S^{*}, 4 S^{*}, 7 R^{*}, 7 a S^{*}\right)-7-m e t h y l-4-p h e n y l-\right.\right.$} 3a,4,5,6,7,7a-hexahydro-1H-4,7-epoxyinden-1-yl]oxy\}silane (syn8h)

Performed on $0.2 \mathrm{mmol}$ scale from $(E)-\mathbf{7 h}(71 \mathrm{mg})$ with stirring for 15 h at $25^{\circ} \mathrm{C}$. Crude ${ }^{1} \mathrm{H}$ NMR yield $=98 \%$ (>96:4 dr). Purified by silica gel column chromatography eluting with cyclohexane $/ \mathrm{CH}_{2} \mathrm{Cl}_{2} / \mathrm{EtOAc}$ (80:17:3 to $80: 15: 5)$ and isolated as a pale yellow oil $(64.4 \mathrm{mg}, 0.181$ mmol, 90\%, 99:1 dr).

${ }^{1} \mathrm{H} \mathrm{NMR}\left(400 \mathrm{MHz}, \mathrm{CDCl}_{3}\right): \delta=7.44-7.39(\mathrm{~m}, 2 \mathrm{H}), 7.38-7.32(\mathrm{~m}, 2 \mathrm{H})$, 7.29-7.24 (m, $1 \mathrm{H}), 6.00$ (ddd, $J=5.6,2.2,0.9 \mathrm{~Hz}, 1 \mathrm{H}), 5.84-5.80(\mathrm{~m}, 1$ $\mathrm{H}), 4.70(\mathrm{tt}, J=2.3,1.2 \mathrm{~Hz}, 1 \mathrm{H}), 3.54(\mathrm{~d}$ quin, $J=9.4,2.0 \mathrm{~Hz}, 1 \mathrm{H}), 2.60$ (dt, $J=9.4,1.7 \mathrm{~Hz}, 1 \mathrm{H}$ ), 1.99 (app ddd, $J=12.4,9.3,4.1 \mathrm{~Hz}, 1 \mathrm{H}$ ), 1.76$1.61(\mathrm{~m}, 2 \mathrm{H}), 1.61(\mathrm{~s}, 3 \mathrm{H}), 1.58-1.51(\mathrm{~m}, 1 \mathrm{H}), 0.91(\mathrm{~s}, 9 \mathrm{H}), 0.12(\mathrm{~s}, 3$ $\mathrm{H}), 0.11(\mathrm{~s}, 3 \mathrm{H})$.

${ }^{13} \mathrm{C} \mathrm{NMR}\left(101 \mathrm{MHz}, \mathrm{CDCl}_{3}\right): \delta=143.3,136.0,135.4,128.4(2 \mathrm{C}), 127.2$, 125.1 (2 C), 89.5, 85.4, 77.5, 63.6, 63.0, 35.1, 32.3, 26.1 (3 C), 22.0, $18.4,-4.1,-4.2$.

HRMS (ESI+): $m / z[\mathrm{M}+\mathrm{Na}]^{+}$calcd for $\mathrm{C}_{22} \mathrm{H}_{32} \mathrm{O}_{2} \mathrm{SiNa}$ : 379.2064; found: 379.2071 .

\section{tert-Butyldimethyl $\left\{\left[\left(1 S^{*}, 3 a S^{*}, 4 R^{*}, 7 S^{*}, 7 a S^{*}\right)-7-m e t h y l-4-p h e n y l-\right.\right.$ 3a,4,5,6,7,7a-hexahydro-1H-4,7-epoxyinden-1-yl]oxy\}silane (anti- 8h)}

Performed on $0.2 \mathrm{mmol}$ scale from $(Z)-7 \mathbf{h}(71 \mathrm{mg})$ with stirring for 18 $\mathrm{h}$ at $25^{\circ} \mathrm{C}$. Crude ${ }^{1} \mathrm{H}$ NMR yield $=77 \%(>98: 2 d r)$. Purified by silica gel column chromatography eluting with pentane/ $/ \mathrm{Et}_{2} \mathrm{O}(95: 5)$ and isolated as an off-white solid ( $58 \mathrm{mg}$ ). Crystallization from hot pentane gave analytically pure material ( $43.5 \mathrm{mg}, 0.122 \mathrm{mmol}, 61 \%,>98: 2 \mathrm{dr}$ ). Mp $72-75{ }^{\circ} \mathrm{C}$ (pentane).

${ }^{1} \mathrm{H}$ NMR $\left(500 \mathrm{MHz}, \mathrm{CDCl}_{3}\right): \delta=7.35-7.27(\mathrm{~m}, 4 \mathrm{H}), 7.26-7.19(\mathrm{~m}, 1 \mathrm{H})$, $5.68(\mathrm{dt}, J=5.7,2.0 \mathrm{~Hz}, 1 \mathrm{H}), 5.21$ (ddd, $J=5.7,2.4,1.2 \mathrm{~Hz}, 1 \mathrm{H}), 4.91$ $(\mathrm{dq}, J=3.3,1.9,1.2 \mathrm{~Hz}, 1 \mathrm{H}), 3.43(\mathrm{dq}, J=6.8,2.2 \mathrm{~Hz}, 1 \mathrm{H}), 2.31(\mathrm{dd}, J=$ 7.0, $2.0 \mathrm{~Hz}, 1 \mathrm{H}), 2.14$ (ddd, $J=10.6,8.6,3.9 \mathrm{~Hz}, 1 \mathrm{H}), 1.89-1.72(\mathrm{~m}, 3$ H), 1.64 (s, $3 \mathrm{H}), 0.90$ (s, $9 \mathrm{H}), 0.12(\mathrm{~s}, 3 \mathrm{H}), 0.10$ (s, $3 \mathrm{H})$.

${ }^{13} \mathrm{C} \mathrm{NMR}\left(126 \mathrm{MHz}, \mathrm{CDCl}_{3}\right): \delta=141.2,135.7,133.2,128.2(2 \mathrm{C}), 126.8$, 125.4 (2 C), 88.2, 84.3, 79.6, 61.3, 61.1, 38.5, 38.4, 26.1 (3 C), 19.0, $18.2,-3.9,-4.2$.

HRMS (ESI+): $m / z$ [M + Na] $]^{+}$calcd for $\mathrm{C}_{22} \mathrm{H}_{32} \mathrm{O}_{2} \mathrm{SiNa}$ : 379.2064; found: 379.2067.

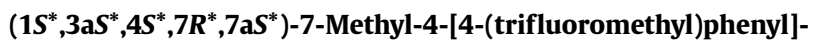
3a,4,5,6,7,7a-hexahydro-1H-4,7-epoxyinden-1-yl Benzoate (syn-8i) Performed on $0.2 \mathrm{mmol}$ scale from $(E)-7 \mathbf{i}(82 \mathrm{mg})$ with stirring for 17 $\mathrm{h}$ at $25^{\circ} \mathrm{C}$. Crude ${ }^{1} \mathrm{H}$ NMR yield $=78 \%$ (83:17 $d r$, yield of combined diastereomers). Purified by preparative silica gel TLC eluting with cyclohexane $/ \mathrm{CH}_{2} \mathrm{Cl}_{2} /$ EtOAc (85:15:5) and isolated as a pale yellow oil (39.6 mg, $0.096 \mathrm{mmol}$, 48\%, 91:9 dr).

${ }^{1} \mathrm{H}$ NMR $\left(400 \mathrm{MHz}, \mathrm{CDCl}_{3}\right): \delta=8.06-8.01(\mathrm{~m}, 2 \mathrm{H}+2 \mathrm{H}$ minor $), 7.66-$ 7.60 ( $\mathrm{m}, 2 \mathrm{H}+2 \mathrm{H}$ minor), 7.59-7.52 ( $\mathrm{m}, 3 \mathrm{H}+1 \mathrm{H}$ minor), 7.47-7.40 (m, $2 \mathrm{H}+4 \mathrm{H}$ minor), 6.23 (ddd, $J=5.7,2.1,1.0 \mathrm{~Hz}, 1 \mathrm{H}$ ), 6.05 (dt, $J=$ 5.6, $2.1 \mathrm{~Hz}, 1 \mathrm{H}$ ), 5.85 (sept, $J=1.3 \mathrm{~Hz}, 1 \mathrm{H}$ ), 3.54 (d quin, $J=8.8,2.2 \mathrm{~Hz}$, $1 \mathrm{H}), 2.80(\mathrm{dt}, J=9.2,1.7 \mathrm{~Hz}, 1 \mathrm{H}), 2.13-2.04(\mathrm{~m}, 1 \mathrm{H}), 1.90-1.81(\mathrm{~m}, 1$ $\mathrm{H}+3 \mathrm{H}$ minor $), 1.80-1.64(\mathrm{~m}, 5 \mathrm{H}+3 \mathrm{H}$ minor $)$.

${ }^{13} \mathrm{C}$ NMR $\left(101 \mathrm{MHz}, \mathrm{CDCl}_{3}\right.$ ): $\delta=166.6,147.0$ (app d, $J_{\mathrm{C}-\mathrm{F}}=1.1 \mathrm{~Hz}$ ), 139.2, 133.2, 132.0, 130.4, 129.8 (2 C), 129.6 (q, $\left.J_{\mathrm{C}-\mathrm{F}}=32.4 \mathrm{~Hz}\right), 128.5$ (2 C), $125.5\left(\mathrm{q}, J_{\mathrm{C}-\mathrm{F}}=4.0 \mathrm{~Hz}, 2 \mathrm{C}\right), 125.5(2 \mathrm{C}), 124.3\left(\mathrm{q}, J_{\mathrm{C}-\mathrm{F}}=271.9 \mathrm{~Hz}\right)$, 89.0, 86.0, 80.1, 63.2, 60.4, 34.9, 32.3, 21.6.

${ }^{19} \mathrm{~F}$ NMR $\left(376 \mathrm{MHz}, \mathrm{CDCl}_{3}\right): \delta=62.55$.

HRMS (ESI+): $m / z$ [M + Na $]^{+}$calcd for $\mathrm{C}_{24} \mathrm{H}_{21} \mathrm{O}_{3} \mathrm{~F}_{3} \mathrm{Na}$ : 437.1335; found: 437.1342.

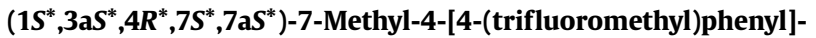
3a,4,5,6,7,7a-hexahydro-1H-4,7-epoxyinden-1-yl Benzoate (anti8i)

Performed on $0.2 \mathrm{mmol}$ scale from $(Z)-7 \mathbf{i}(100 \mathrm{mg})$ with stirring for $17 \mathrm{~h}$ at $25^{\circ} \mathrm{C}$. Crude ${ }^{1} \mathrm{H}$ NMR yield $=99 \%$ (86:14 dr, yield of combined diastereomers). Purified by preparative silica gel TLC eluting with cyclohexane $/ \mathrm{CH}_{2} \mathrm{Cl}_{2} /$ EtOAc (85:12:3) and isolated as a colorless solid (54 $\mathrm{mg}, 0.13 \mathrm{mmol}, 65 \%>98: 2 \mathrm{dr})(22 \mathrm{mg}$ of a fraction containing a $57: 43$ $d r$ mixture of diastereomers was also collected, 27\%).

Mp $108-110^{\circ} \mathrm{C}$.

${ }^{1} \mathrm{H}$ NMR $\left(400 \mathrm{MHz}, \mathrm{CDCl}_{3}\right): \delta=8.06-8.01(\mathrm{~m}, 2 \mathrm{H}), 7.60$ (app d, $J=8.2$ $\mathrm{Hz}, 2 \mathrm{H}$ ), 7.55 (ddt, $J=8.7,6.9,1.4 \mathrm{~Hz}, 1 \mathrm{H}), 7.48-7.40$ (m, $4 \mathrm{H}), 6.05$ (app dt, $J=3.2,1.8 \mathrm{~Hz}, 1 \mathrm{H}), 5.91(\mathrm{dt}, J=5.7,2.1 \mathrm{~Hz}, 1 \mathrm{H}), 5.38$ (ddd, $J=$ 5.7, 2.3, $1.2 \mathrm{~Hz}, 1 \mathrm{H}$ ), 3.53 (dq, $J=6.7,2.2 \mathrm{~Hz}, 1 \mathrm{H}$ ), 2.58 (dd, $J=6.8,1.8$ $\mathrm{Hz}, 1 \mathrm{H}), 2.25-2.17$ (m, $1 \mathrm{H}), 1.94-1.80$ (m, $3 \mathrm{H}), 1.77$ (s, $3 \mathrm{H})$.

${ }^{13} \mathrm{C}$ NMR $\left(101 \mathrm{MHz}, \mathrm{CDCl}_{3}\right): \delta=166.3,144.9\left(\right.$ app d, $\left.J_{\mathrm{C}-\mathrm{F}}=1.1 \mathrm{~Hz}\right)$ 136.4, 133.1, 132.1, 130.6, 129.7 (2 C), 129.3 (q, J $\left.J_{C-F}=32.3 \mathrm{~Hz}\right), 128.5$ $(2 \mathrm{C}), 125.9(2 \mathrm{C}), 125.2\left(\mathrm{q}, J_{\mathrm{C}-\mathrm{F}}=3.8 \mathrm{~Hz}, 2 \mathrm{C}\right), 124.4\left(\mathrm{q}, J_{\mathrm{C}-\mathrm{F}}=271.9 \mathrm{~Hz}\right)$, 87.6, 84.8, 82.1, 61.6, 57.6, 38.3, 38.1, 18.7 .

${ }^{19} \mathrm{~F}$ NMR (376 MHz, $\left.\mathrm{CDCl}_{3}\right): \delta=-62.53$.

HRMS (ESI+): $m / z[\mathrm{M}+\mathrm{Na}]^{+}$calcd for $\mathrm{C}_{24} \mathrm{H}_{21} \mathrm{O}_{3} \mathrm{~F}_{3} \mathrm{Na}$ : 437.1335; found: 437.1338.

$\left(1 S^{*}, 3 \mathrm{a} S^{*}, 4 R^{*}, 7 S^{*}, 7 \mathrm{a} S^{*}\right)-7-M e t h y l-4-($ naphthalen-2-yl)3a,4,5,6,7,7a-hexahydro-1H-4,7-epoxyinden-1-yl Benzoate (anti8j)

Performed on $0.2 \mathrm{mmol}$ scale from $(Z)-\mathbf{7 j}$ (79 mg) with stirring for 17 h at $25{ }^{\circ} \mathrm{C}$. Crude ${ }^{1} \mathrm{H}$ NMR yield $=78 \%$ (94:6 dr). Purified by preparative silica gel TLC eluting with cyclohexane/ $\mathrm{CH}_{2} \mathrm{Cl}_{2} / \mathrm{EtOAC}(85: 12: 3)$ and isolated as a pale yellow oil that solidified on standing. Further crystallization from $\mathrm{CH}_{2} \mathrm{Cl}_{2}(200 \mu \mathrm{L})+\mathrm{Et}_{2} \mathrm{O}(200 \mu \mathrm{L})+$ pentane $(1.2$ $\mathrm{mL}$ ), first at $4{ }^{\circ} \mathrm{C}$ for $2 \mathrm{~h}$ then at $-30{ }^{\circ} \mathrm{C}$ for $16 \mathrm{~h}$, gave $33 \mathrm{mg}$ of a colorless solid $(42 \%,>98: 2 d r)$. The filtrate was recrystallized from $\mathrm{CH}_{2} \mathrm{Cl}_{2}$ $(100 \mu \mathrm{L})+\mathrm{Et}_{2} \mathrm{O}(100 \mu \mathrm{L})+$ pentane $(0.8 \mathrm{~mL})$ to give a second crop of 11 $\mathrm{mg}$ of colorless solid $(14 \%,>98: 2 \mathrm{dr})$. Overall yield after crystallization was $56 \%(>98: 2 d r)$.

Mp $125-126{ }^{\circ} \mathrm{C}\left(\mathrm{CH}_{2} \mathrm{Cl}_{2} / \mathrm{Et}_{2} \mathrm{O} /\right.$ pentane $)$. 
${ }^{1} \mathrm{H}$ NMR $\left(500 \mathrm{MHz}, \mathrm{CDCl}_{3}\right): \delta=8.09-8.02(\mathrm{~m}, 2 \mathrm{H}), 7.89-7.80(\mathrm{~m}, 4 \mathrm{H})$, 7.59-7.53 (m, $1 \mathrm{H}), 7.52-7.40(\mathrm{~m}, 5 \mathrm{H}), 6.14-6.09(\mathrm{~m}, 1 \mathrm{H}), 5.90(\mathrm{dt}, J=$ 5.7, $2.1 \mathrm{~Hz}, 1 \mathrm{H}), 5.44$ (ddd, $J=5.8,2.1,1.1 \mathrm{~Hz}, 1 \mathrm{H}$ ), $3.62(\mathrm{dq}, J=6.7$, $2.2 \mathrm{~Hz}, 1 \mathrm{H}$ ), 2.61 (dd, $J=6.7,1.8 \mathrm{~Hz}, 1 \mathrm{H}$ ), 2.30 (ddd, $J=11.3,8.5,4.9$ $\mathrm{Hz}, 1 \mathrm{H}), 1.99$ (td, $J=11.7,5.1 \mathrm{~Hz}, 1 \mathrm{H}$ ), 1.95-1.85 (m, $2 \mathrm{H}$ ), 1.83 (s, 3 $\mathrm{H})$.

${ }^{13} \mathrm{C}$ NMR $\left(101 \mathrm{MHz}, \mathrm{CDCl}_{3}\right): \delta=166.3,138.4,137.2,133.3,133.0$, 132.6, 131.6, 130.7, 129.7 (2 C), 128.5 (2 C), 128.2, 128.0, 127.8, 126.2, $125.8,123.9,123.8,88.1,84.6,82.3,61.6,57.6,38.5,38.4,18.9$.

HRMS (ESI+): $m / z[\mathrm{M}+\mathrm{Na}]^{+}$calcd for $\mathrm{C}_{27} \mathrm{H}_{24} \mathrm{O}_{3} \mathrm{Na}$ : 419.1618; found: 419.1614.

\section{Crown Ether 9}

A solution of $(E)-7 \mathbf{k}(20 \mathrm{mg}, 0.1 \mathrm{mmol})$ and [JohnPhosAu(NCMe)]SbF 6 complex (3 mol\%) in anhydrous $\mathrm{CH}_{2} \mathrm{Cl}_{2}(1 \mathrm{~mL})$ was stirred at $0{ }^{\circ} \mathrm{C}$ for $10 \mathrm{~h}$. It was then quenched by addition of $\mathrm{Et}_{3} \mathrm{~N}(5 \mu \mathrm{L})$ and the solvent was removed in vacuo (at $25{ }^{\circ} \mathrm{C}$ ). The crude material was purified by silica gel column chromatography eluting with cyclohexane/EtOAc (90:10) and isolated as a white solid ( $8.1 \mathrm{mg}, 0.024 \mathrm{mmol}, 49 \%)$. Note: the reaction was performed under an air atmosphere.

Mp $258-260{ }^{\circ} \mathrm{C}$

${ }^{1} \mathrm{H}$ NMR (500 MHz, $\mathrm{CDCl}_{3}$ ): $\delta=5.83-5.79(\mathrm{~m}, 2 \mathrm{H}$ ), 5.63 (app ddd, $J=$ $5.6,4.3,2.5 \mathrm{~Hz}, 2 \mathrm{H}), 5.33$ (dd, $J=6.1,2.6 \mathrm{~Hz}, 2 \mathrm{H}), 4.72(\mathrm{~d}, J=6.0 \mathrm{~Hz}, 2$ H), 3.27 (app q, $J=2.1 \mathrm{~Hz}, 2 \mathrm{H}), 2.63(\mathrm{ddt}, J=17.8,8.2,2.2 \mathrm{~Hz}, 2 \mathrm{H})$, 2.35 (dt, $J=17.9,2.1 \mathrm{~Hz}, 2 \mathrm{H}), 2.28-2.19(\mathrm{~m}, 2 \mathrm{H}), 2.13-2.07(\mathrm{~m}, 2 \mathrm{H})$, 2.06-1.98 (m, $2 \mathrm{H}), 1.64-1.54(\mathrm{~m}, 2 \mathrm{H}), 1.02(\mathrm{~s}, 6 \mathrm{H})$.

${ }^{13} \mathrm{C}$ NMR (126 MHz, $\mathrm{CDCl}_{3}$ ): $\delta=131.1$ (2 C), $130.6(2 \mathrm{C}), 102.4(2 \mathrm{C})$, 85.3 (2 C), 76.1 (2 C), 63.6 (2 C), 40.6 (2 C), 36.6 (2 C), 33.1 (2 C), 22.2 (2 C)

HRMS (ESI+): $m / z[\mathrm{M}+\mathrm{Na}]^{+}$calcd for $\mathrm{C}_{20} \mathrm{H}_{28} \mathrm{O}_{4} \mathrm{Na}$ : 355.1880; found: 355.1868 .

This compound was crystallized from $\mathrm{CHCl}_{3}$ to obtain single crystals suitable for X-ray diffraction (see Supporting Information).

\section{Acknowledgment}

We thank MINECO (Severo Ochoa Excellence Accreditation 20142018 (SEV-2013-0319), project CTQ2013-42106-P), the MEC (FPU pre-doctoral fellowship to P.C.), the European Research Council (Advanced Grant No. 321066), the AGAUR (2014 SGR 818), and the ICIQ Foundation. We also acknowledge the COFUND postdoctoral program (Marie Curie actions) for a postdoctoral fellowship to M.E.M.

\section{Supporting Information}

Supporting information for this article is available online at http://dx.doi.org/10.1055/s-0035-1562452.

\section{References}

(1) (a) Zhang, L.; Sun, J.; Kozmin, S. A. Adv. Synth. Catal. 2006, 348, 2271. (b) Fürstner, A.; Davies, P. W. Angew. Chem. Int. Ed. 2007, 46, 3410. (c) Hashmi, A. S. K. Chem. Rev. 2007, 107, 3180. (d) Li,
Z.; Brouwer, C.; He, C. Chem. Rev. 2008, 108, 3239. (e) Arcadi, A. Chem. Rev. 2008, 108, 3266. (f) Jiménez-Núñez, E.; Echavarren, A. M. Chem. Rev. 2008, 108, 3326. (g) Gorin, D. J.; Sherry, B. D.; Toste, F. D. Chem. Rev. 2008, 108, 3351. (h) Michelet, V.; Toullec, P. Y.; Genêt, J.-P. Angew. Chem. Int. Ed. 2008, 47, 4268. (i) Aubert, C.; Fensterbank, L.; Garcia, P.; Malacria, M.; Simonneau, A. Chem. Rev. 2011, 111, 1954. (j) Krause, N.; Winter, C. Chem. Rev. 2011, 111, 1994. (k) Obradors, C.; Echavarren, A. M. Acc. Chem. Res. 2014, 47, 902. (l) Fensterbank, L.; Malacria, M. Acc. Chem. Res. 2014, 47, 953. (m) Dorel, R.; Echavarren, A. M. Chem. Rev. 2015, $115,9028$.

(2) For reviews on the total synthesis of natural products using gold(I) catalysis, see: (a) Hashmi, A. S. K.; Rudolph, M. Chem. Soc. Rev. 2008, 37, 1766. (b) Rudolph, M.; Hashmi, A. S. K. Chem. Commun. 2011, 47, 6536. (c) Rudolph, M.; Hashmi, A. S. K. Chem. Soc. Rev. 2012, 41, 2448. (d) Fürstner, A. Acc. Chem. Res. 2014, 47, 925. (e) Zhang, Y.; Luo, T.; Yang, Z. Nat. Prod. Rep. 2014, 31, 489.

(3) See our previous reports on the total synthesis of terpenoids using gold(I) catalysis: (a) Jiménez-Núñez, E.; Molawi, K.; Echavarren, A. M. Chem. Commun. 2009, 7327. (b) Molawi, K.; Delpont, N.; Echavarren, A. M. Angew. Chem. Int. Ed. 2010, 49, 3517. (c) Gaydou, M.; Miller, R. E.; Delpont, N.; Ceccon, J.; Echavarren, A. M. Angew. Chem. Int. Ed. 2013, 52, 6396. (d) Carreras, J.; Livendahl, M.; McGonigal, P. R.; Echavarren, A. M. Angew. Chem. Int. Ed. 2014, 53, 4896.

(4) Jiménez-Núñez, E.; Claverie, C. K.; Nieto-Oberhuber, C.; Echavarren, A. M. Angew. Chem. Int. Ed. 2006, 45, 5452.

(5) Obradors, C.; Echavarren, A. M. Chem. Eur. J. 2013, 19, 3547.

(6) Muratore, M. E.; Homs, A.; Obradors, C.; Echavarren, A. M. Chem. Asian J. 2014, 9, 3066.

(7) Jiménez, T.; Carreras, J.; Ceccon, J.; Echavarren, A. M. Org. Lett. 2016, 18, 1410.

(8) (a) Faustino, H.; Alonso, I.; Mascareñas, J. L. Angew. Chem. Int. Ed. 2013, 52, 6526. (b) Faustino, H.; Varela, I.; Mascareñas, J. L.; López, F. Chem. Sci. 2015, 6, 2903.

(9) Zhou, Q.; Chen, X.; Ma, D. Angew. Chem. Int. Ed. 2010, 49, 3513.

(10) Kobayashi, M.; Yasuzawa, T.; Kyogoku, Y.; Kido, M.; Kitagawa, I. Chem. Pharm. Bull. 1982, 30, 3431.

(11) Jiang, C.-H.; Bhattachrayya, A.; Sha, C.-K. Org. Lett. 2007, 9, 3241; and references therein.

(12) Huguet, N.; Echavarren, A. M. Synlett 2012, 23, 49.

(13) In this case the addition of methanol to the ketone as well as dimethyl acetal formation on the aldehyde was observed exclusively.

(14) CCDC 1481203 (anti-8a), CCDC 1481204 (anti-8b), CCDC 1483401 (syn-8c), CCDC 1481205 (anti-8g) and CCDC 1481206 (9) contain the supplementary crystallographic data for this paper. These data can be obtained free of charge from the Cambridge Crystallographic Data Centre via www.ccdc.cam.ac.uk/getstructures.

(15) López-Carrillo, V.; Huguet, N.; Mosquera, Á.; Echavarren, A. M. Chem. Eur. J. 2011, 17, 10972.

(16) (a) Wilson, M. S.; Woo, J. C. S.; Dake, G. R. J. Org. Chem. 2006, 71, 4237. (b) Yang, M.; Dong, H.; Jiang, J.; Wang, M. Molecules 2015, $20,21023$.

(17) Zhong, Y.-L.; Shing, T. K. M. J. Org. Chem. 1997, 62, 2622. 